INTERNATIONAL MONETARY FUND

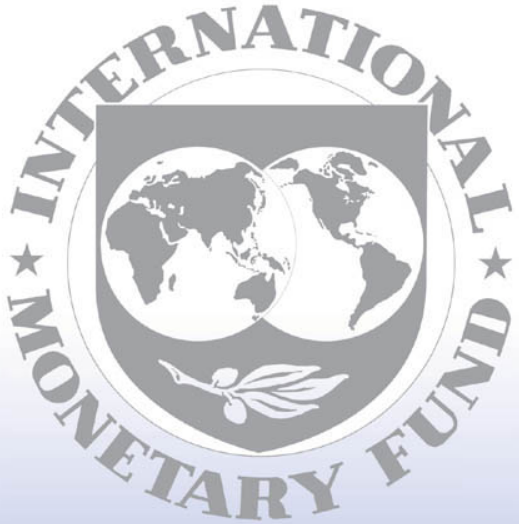

Staff

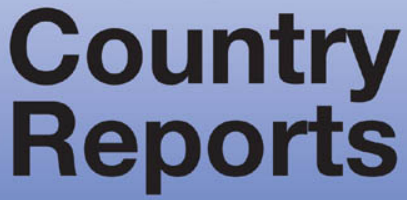




\title{
Former Yugoslav Republic of Macedonia: 2008 Article IV Consultation-Staff Report; Public Information Notice on the Executive Board Discussion; and Statement by the Executive Director for the former Yugoslav Republic of Macedonia
}

Under Article IV of the IMF's Articles of Agreement, the IMF holds bilateral discussions with members, usually every year. In the context of the Article IV consultation with the former Yugoslav Republic of Macedonia, the following documents have been released and are included in this package:

- $\quad$ The staff report for the 2008 Article IV consultation, prepared by a staff team of the IMF, following discussions that ended on September 22, 2008, with the officials of the former Yugoslav Republic of Macedonia on economic developments and policies. Based on information available at the time of these discussions, the staff report was completed on November 11, 2008. The views expressed in the staff report are those of the staff team and do not necessarily reflect the views of the Executive Board of the IMF.

- $\quad$ A Public Information Notice (PIN) summarizing the views of the Executive Board as expressed during its December 1, 2008 discussion of the staff report that concluded the Article IV consultation.

- A statement by the Executive Director for the former Yugoslav Republic of Macedonia.

The document listed below has been or will be separately released.

\section{Selected Issues Paper}

The policy of publication of staff reports and other documents allows for the deletion of market-sensitive information.

\author{
Copies of this report are available to the public from \\ International Monetary Fund $\bullet$ Publication Services \\ $70019^{\text {th }}$ Street, N.W. • Washington, D.C. 20431 \\ Telephone: (202) 623-7430 • Telefax: (202) 623-7201 \\ E-mail: publications@imf.org Internet: http://www.imf.org
}

\section{International Monetary Fund Washington, D.C.}


This page intentionally left blank 


\section{INTERNATIONAL MONETARY FUND}

\section{FORMER YUGOSLAV REPUBLIC OF MACEDONIA}

\section{Staff Report for the 2008 Article IV Consultation}

Prepared by Staff Representatives for the 2008 Consultation with

Former Yugoslav Republic of Macedonia

Approved by Poul M. Thomsen and Adnan Mazarei

November 11, 2008

Contents

Page

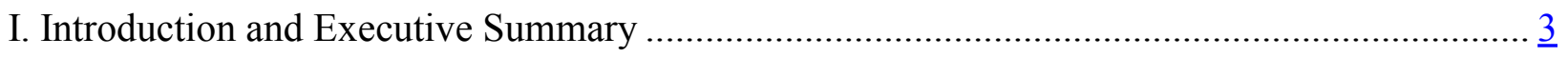

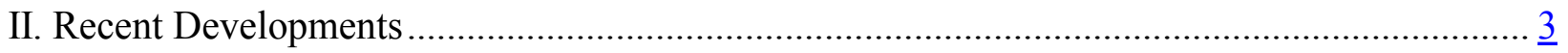

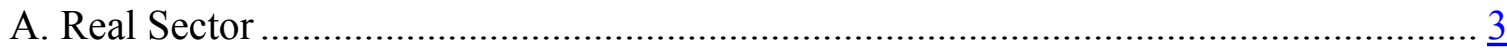

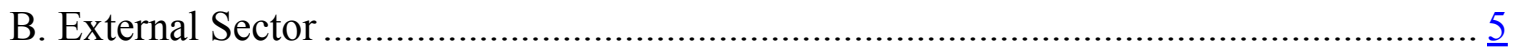

III. The Policy Response ………………………………..............................................

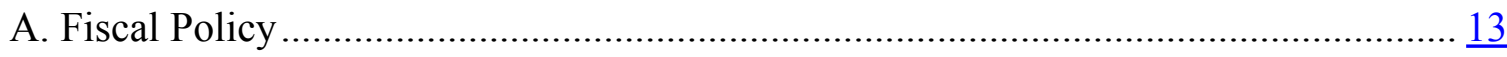

B. Monetary and Financial Sector........................................................................... $\frac{18}{25}$

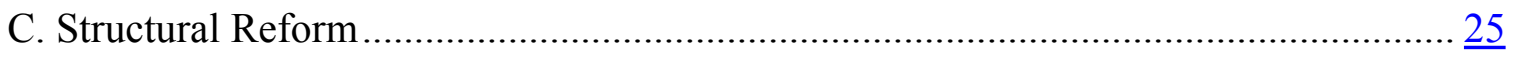

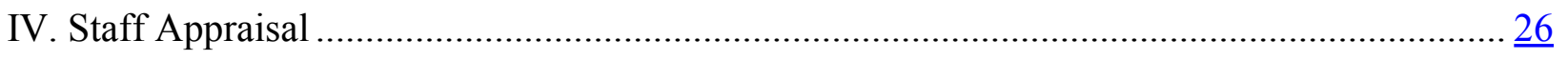

Tables

1. Effectiveness of Fund Policy Advice …………………................................................ 28

2. Selected Economic Indicators, 2004-08

3. Balance of Payments (Baseline), 2007-13 …………………………………………....... $\frac{31}{33}$

4. Indicators of Financial and External Vulnerability, 2004-08 ……………………………... $\frac{33}{34}$

5. Central Government Operations, 2006-09 ………………………………………….... $\frac{34}{36}$

6. Macroeconomic Framework (Baseline), 2007-13 ………………………………………... $\frac{36}{37}$

7. Macroeconomic Framework (Staff Alternative), 2007-13……………………………….... $\frac{37}{38}$

8. Central Bank Accounts, 2005-09 …………………..................................................... $\underline{38}$

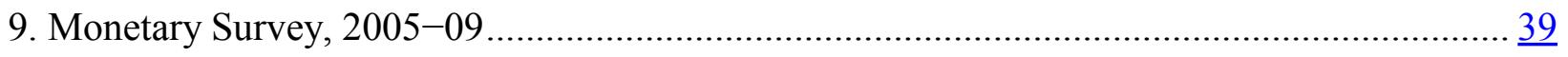

10. Financial Soundnes Indicators, 2004-08 ………….....................................................

11. Main Findings of the 2008 FSAP Update ...................................................................... 41 
12. External Debt Sustainability Framework (Baseline), 2003-13 ........................................ 42

13. Fiscal Debt Sustainability Framework (Baseline), 2003-13 …...................................... 43

14. Composition of Central Government Debt, 2007-08 .................................................... 44

15. Level and Composition of External Debt, 2004-08 …................................................ 45

16. Rankings of Selected Competitiveness and Structural Indicators..................................... 46

Figures

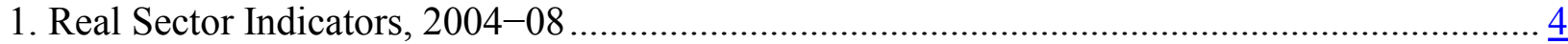

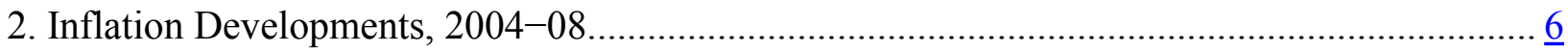

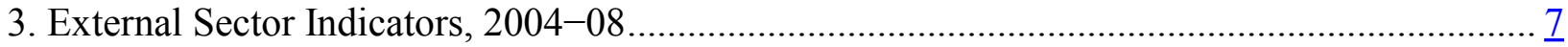

4. Recent Current Account Developments, 2006-08 ….................................................... $\underline{8}$

5. Indicators of External Vulnerability, 2004-08 .......................................................... 12

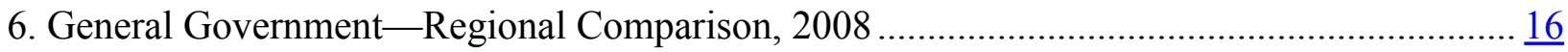

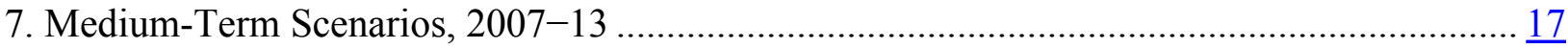

8. Financial Market Developments, 2006-08 .............................................................. 19

9. Credit Developments, 2004-08 ......................................................................... 20

10. Banking Sector Developments, 2004-08............................................................... 23

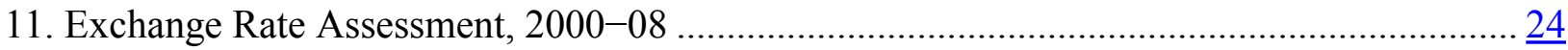

Boxes

1. Implications of International Financial Turmoil ....................................................... 11

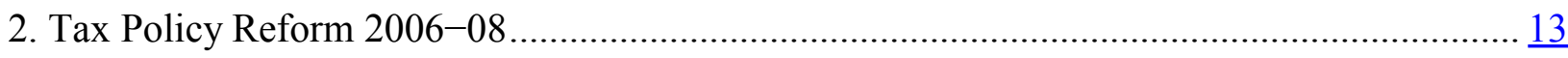

3. Assessment of Competitiveness and External Stability .................................................... 22 


\section{INTRODUCTION AND EXECUTIVE SUMMARY}

1. Macroeconomic vulnerabilities are growing, while the expiry of the Fund arrangement in August means the loss of an important macroeconomic policy anchor. Performance under the program has generally been good, especially at first (Table 1). Growth this year is expected to reach 6 percent, up from 5 percent in 2007, while living standards and employment have improved. However, a shift to more expansionary policies increased external vulnerabilities, with the current account deficit rising to a projected 14 percent of GDP this year. As a result, international reserves are projected to fall below three months of imports, and other indicators of external vulnerability are worsening.

2. The new government's economic program aims to raise growth further, but does not address these vulnerabilities. Plans to increase the central government deficit permanently to about 2 percent of GDP (in the election manifesto) or perhaps even higher (the new government's revised plan presented during the mission) risk worsening external vulnerabilities. Though the fixed exchange rate regime has served the economy well, under these new policies it may come under pressure. The mission therefore called for containing the current account deficit by limiting fiscal expansion to allowing the automatic stabilizers to work. Together with some monetary tightening, this would protect the peg.

\section{Although the mission took place before the intensification of international} financial turmoil, its focus on policies to reduce external vulnerability remains relevant. However, the turmoil means that this report's projections have greater than normal uncertainty. If the turmoil continues, they are subject to considerable downside risk.

\section{RECENT DEVELOPMENTS}

\section{A. Real Sector}

\section{Growth has been strong, but inflation and the current account deficit have worsened}

\section{Growth has picked up, led by stronger domestic demand and increasing} investment, in part FDI related (Figure 1, Table 2). In 2007 improved terms of trade and remittances boosted incomes and domestic demand. This raised growth to 5 percent. Though these favorable shocks have reversed, in the first half of 2008 growth increased to 6 percent (led by construction, wholesale and retail

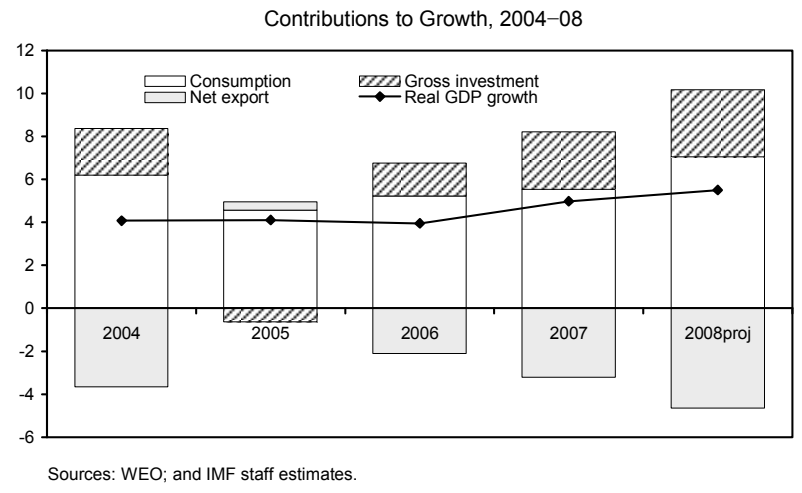


Figure 1. FYR Macedonia: Real Sector Indicators, 2004-08

Official data shows growth has been robust...

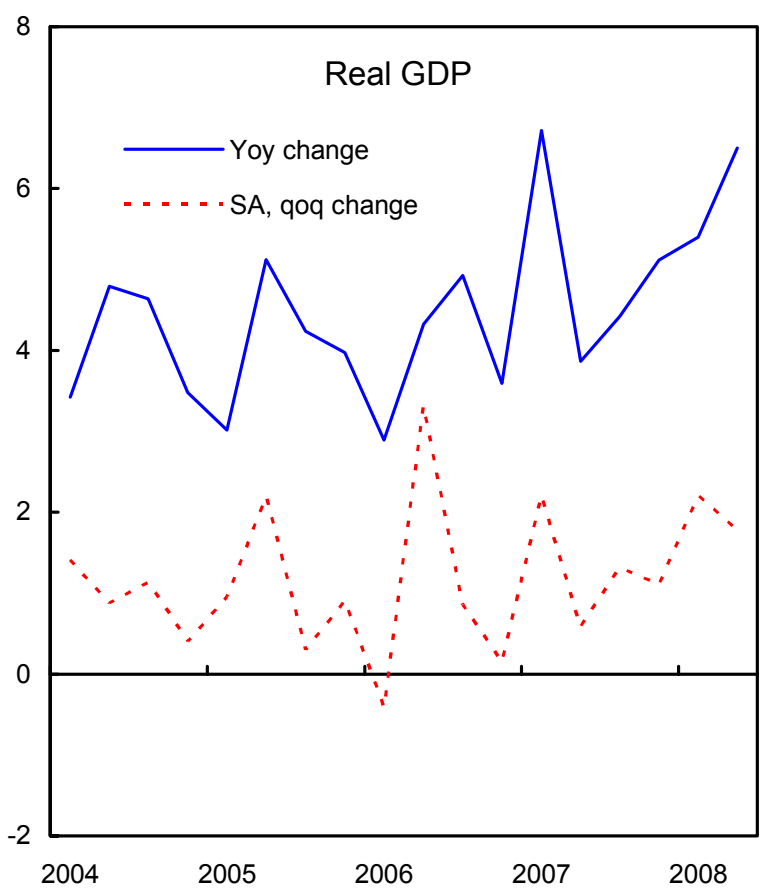

...brisk car sales...

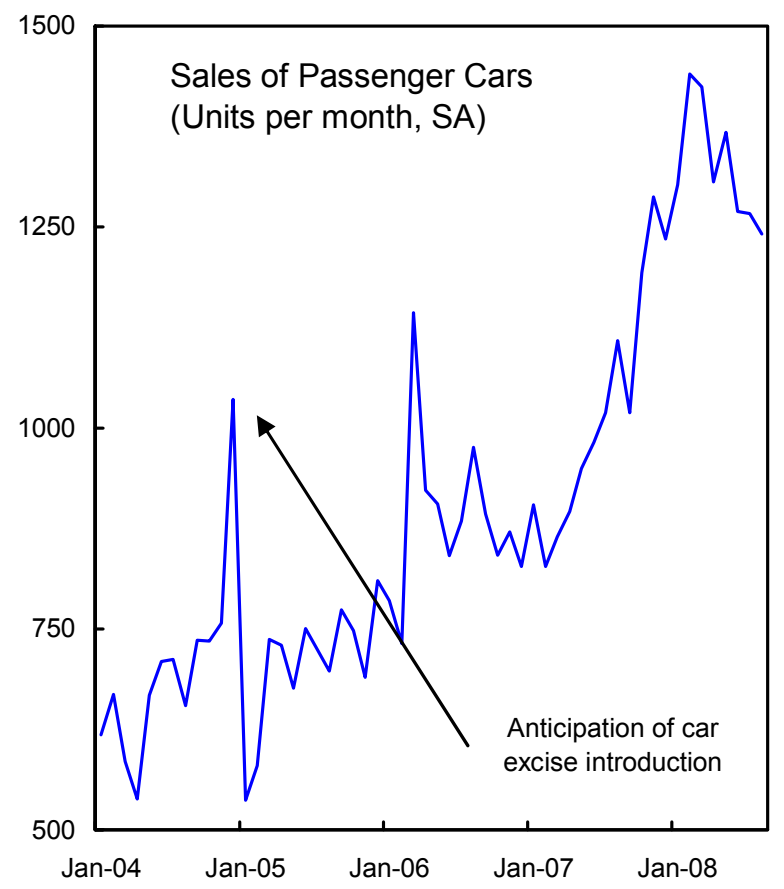

...supported by rising industrial production...

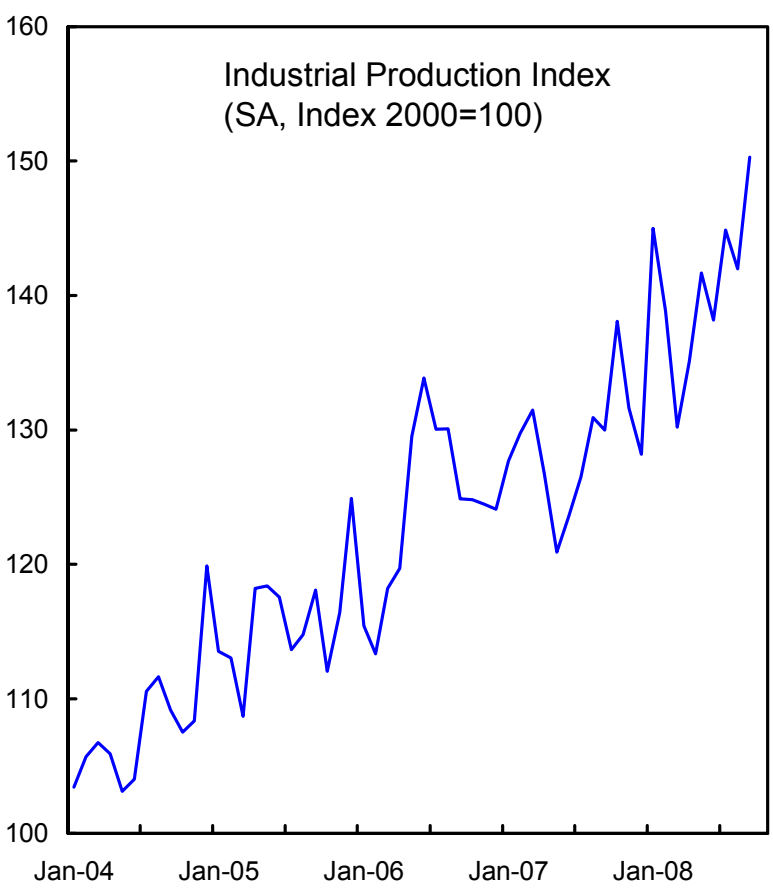

....and higher construction.

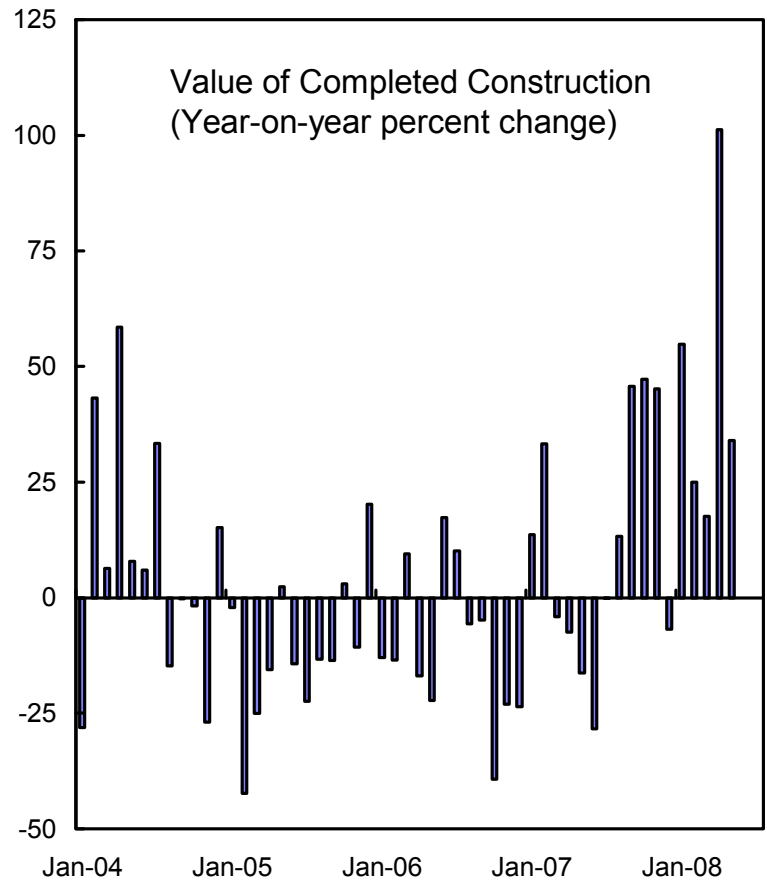

Sources: State Statistical Office; NBRM; and IMF staff estimates. 
trade) while industrial production growth reached double digits. Strong investment (in part reflecting higher FDI) and the high unemployment rate (still around 35 percent; discussed in Country Report 06/345) suggest few capacity constraints and considerable scope for continuing this favorable supply response. But there is plenty of room for catch up.
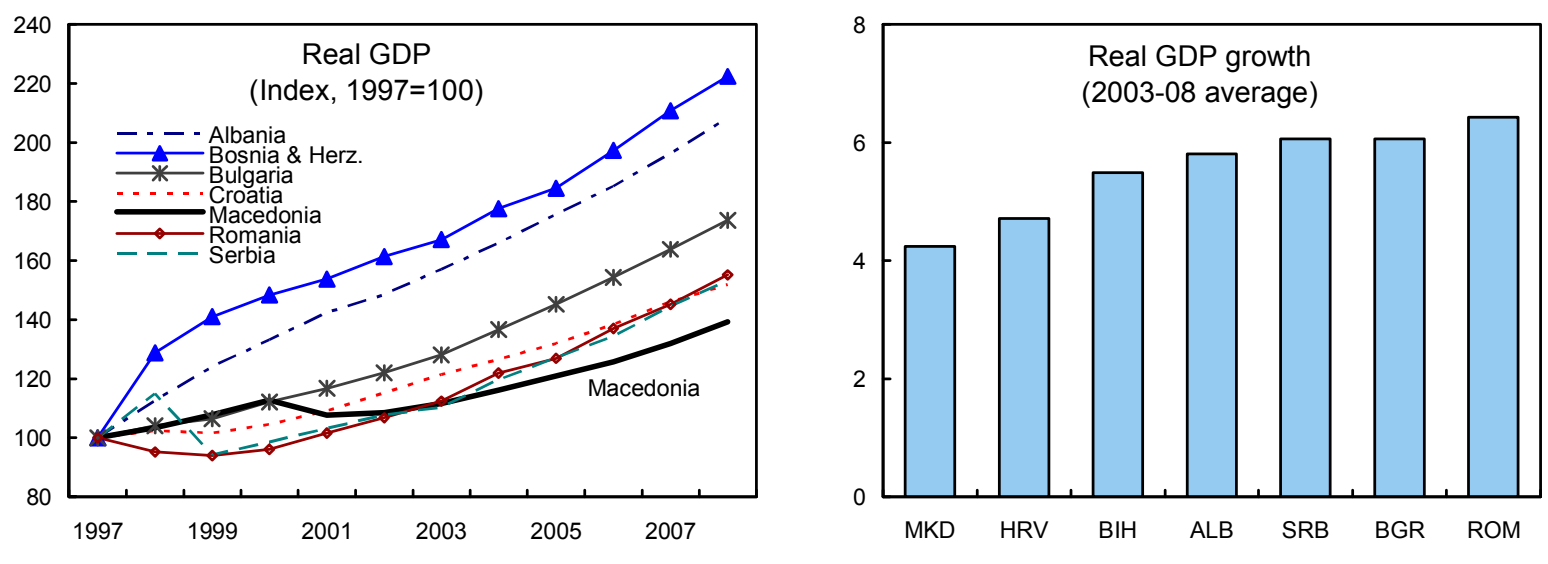

Sources: NBRM; WEO; and IMF staff estimates.

5. Inflation has risen despite the exchange rate anchor, mainly because of outside supply shocks (Figure 2). From 2002 to 2006 inflation averaged less than 1 percent, sometimes with periods of deflation. This was low given the potential for productivity convergence and associated Balassa-Samuelson effects. Inflation jumped to around 10 percent in early 2008, similar to the region, largely because of oil and food price increases (more than 30 percent of the basket) which should be one-off. Public sector wages have been increased substantially (10 percent each year for three years starting September 2007; private sector wages partially followed), as have pensions (13 percent in January 2008, a further 7.3 percent in July). Although higher inflation eroded any real wage increase, the nominal wage increases did insulate real incomes from the supply shocks. With core inflation low at around 3 percent, second-round effects on inflation have been limited, because of slack in the economy and because demand has spilled over to the current account.

\section{B. External Sector}

6. The main risk to growth and macroeconomic stability is the widening current account deficit (Figures 3-4, Table 3). Both, the current account deficit's size (more than 10 percent of GDP in the last 12 months, high for Macedonia and now comparable to vulnerable countries in the region) and its rate of deterioration are significant. 
Figure 2. FYR Macedonia: Inflation Developments, 2004-08

Headline inflation has risen, similar to the region...

...but core inflation has remained low.
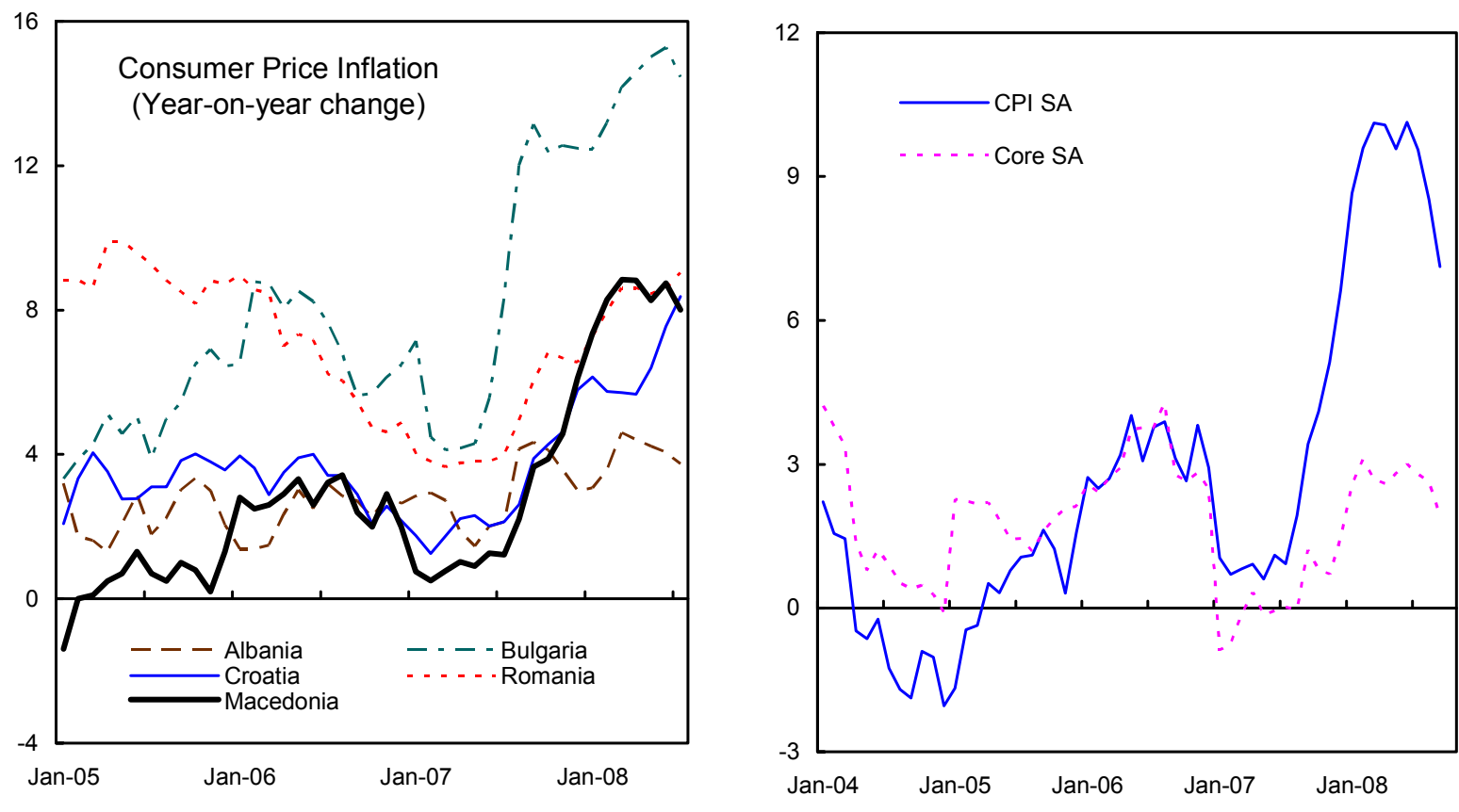

Nominal wages have increased ...

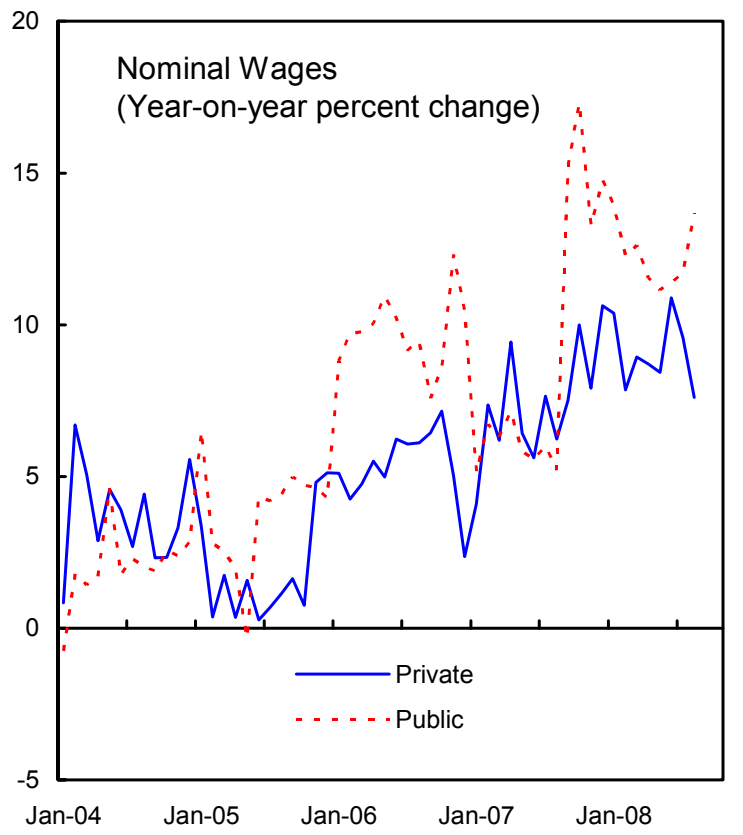

$\ldots$ and the government has raised pensions significantly.

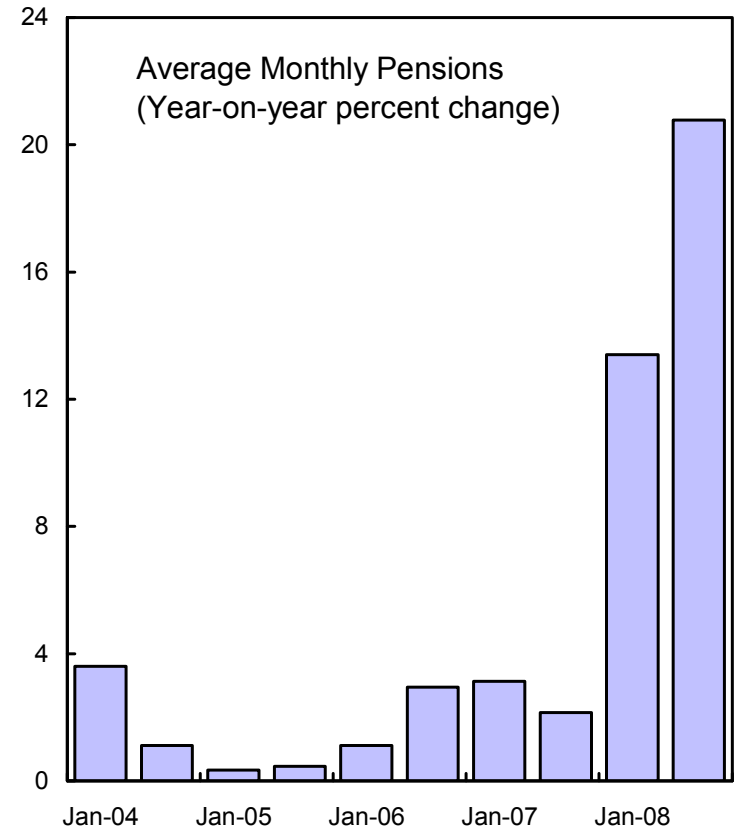

Sources: NBRM; SSO; and IMF staff estimates. 
Figure 3. FYR Macedonia: External Sector Indicators, 2004-08

Current account and trade deficits have risen sharply...

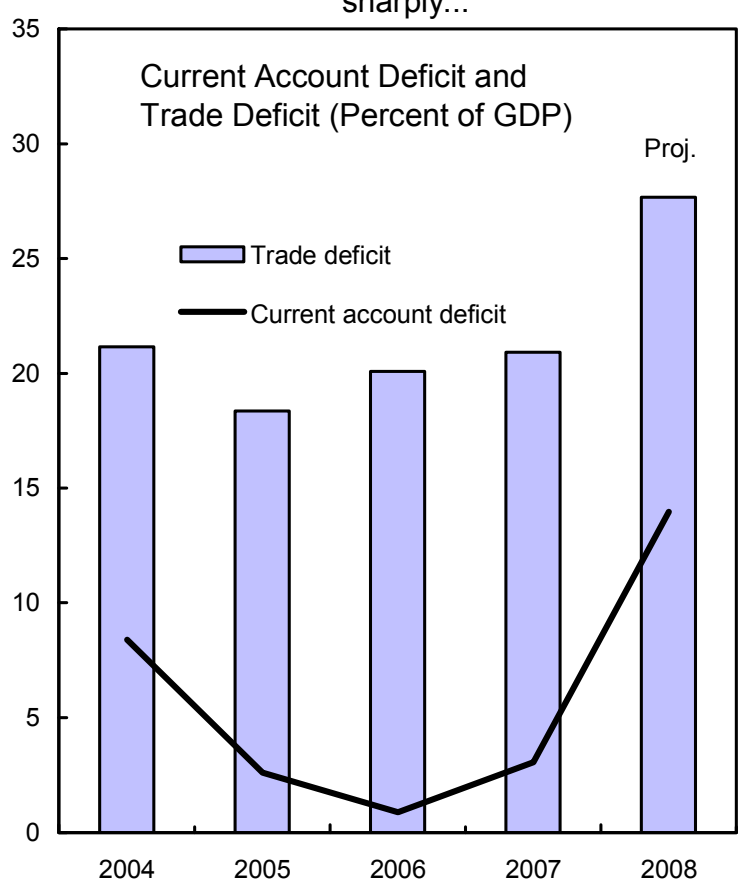

...driven by higher FDI-related imports and lower private transfers...
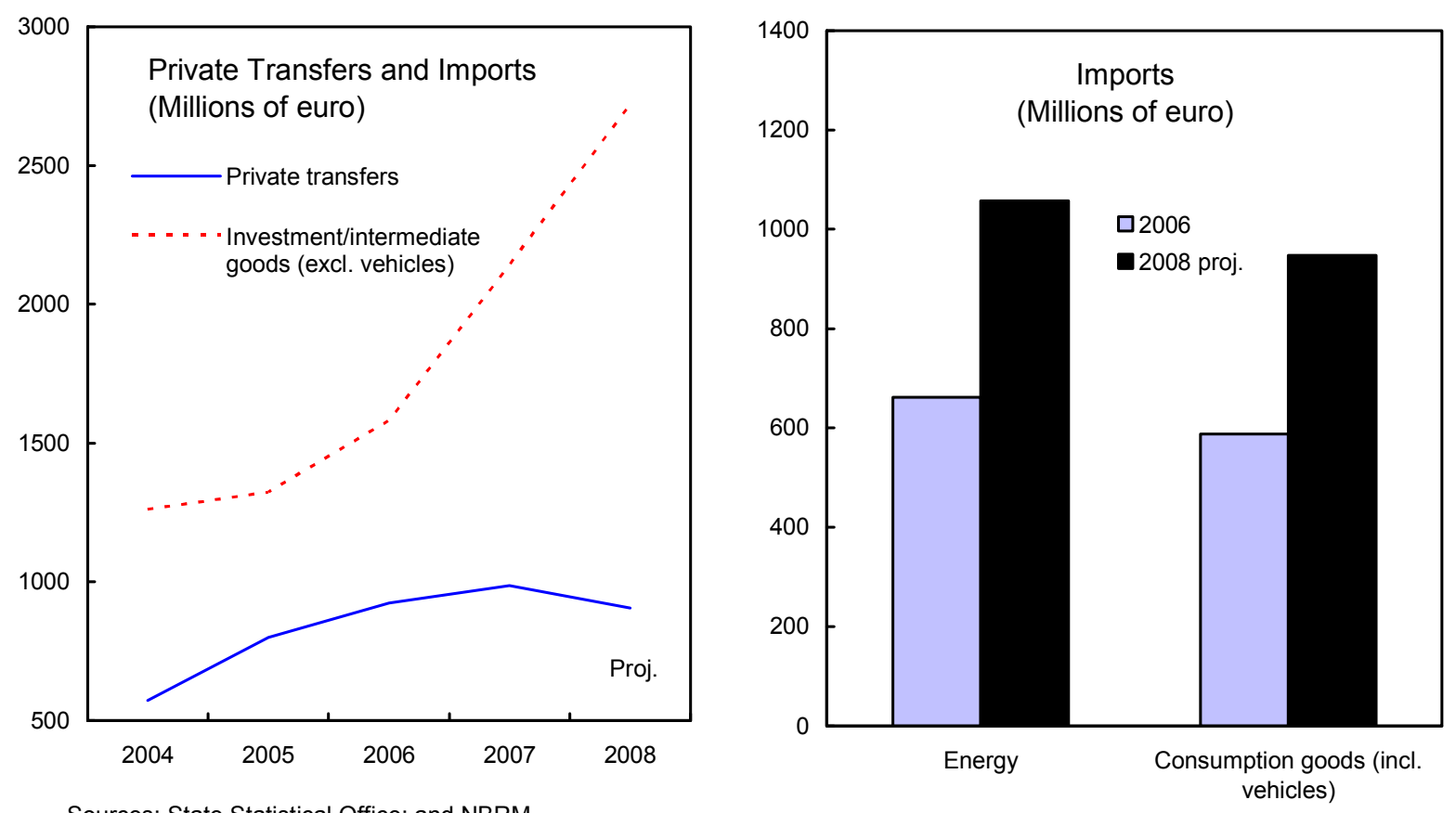
Figure 4. FYR Macedonia: Recent Current Account Developments, 2006-08

The current account deficit over the last 12 months has reached 11 percent of GDP...

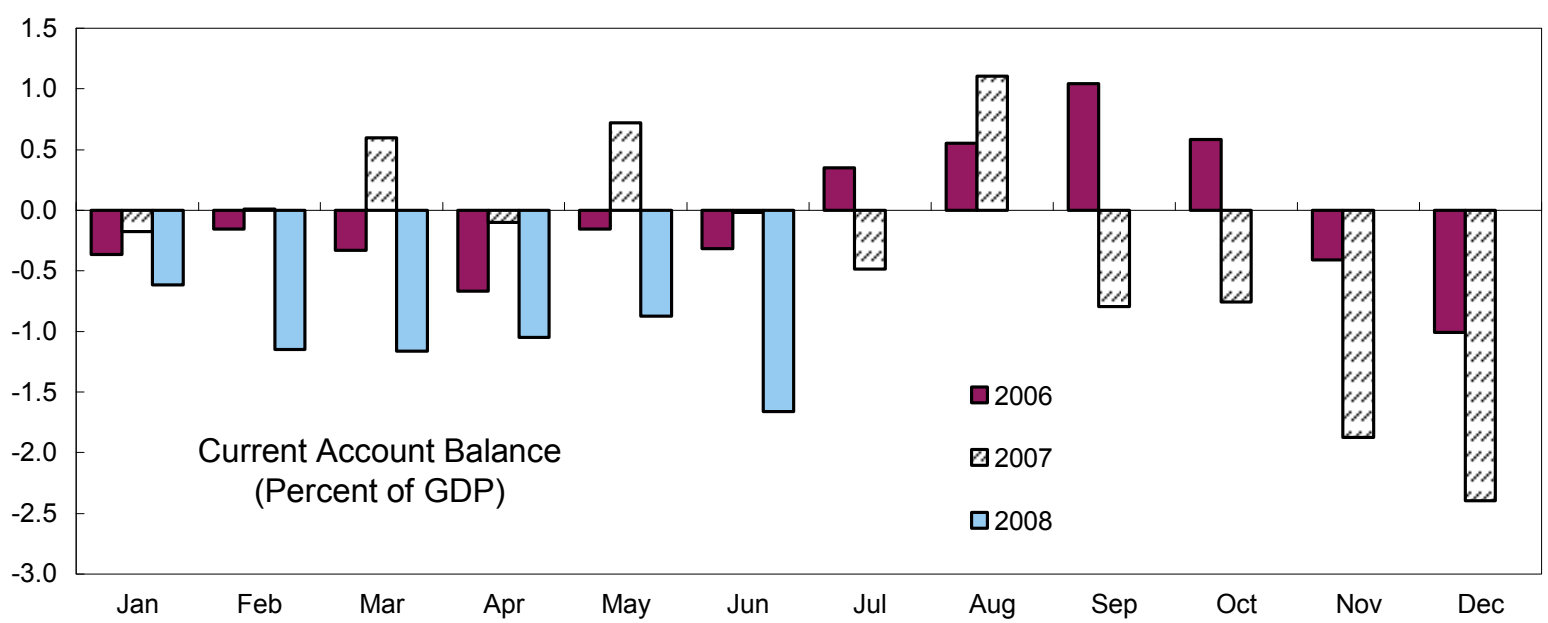

...driven by a growing trade deficit...

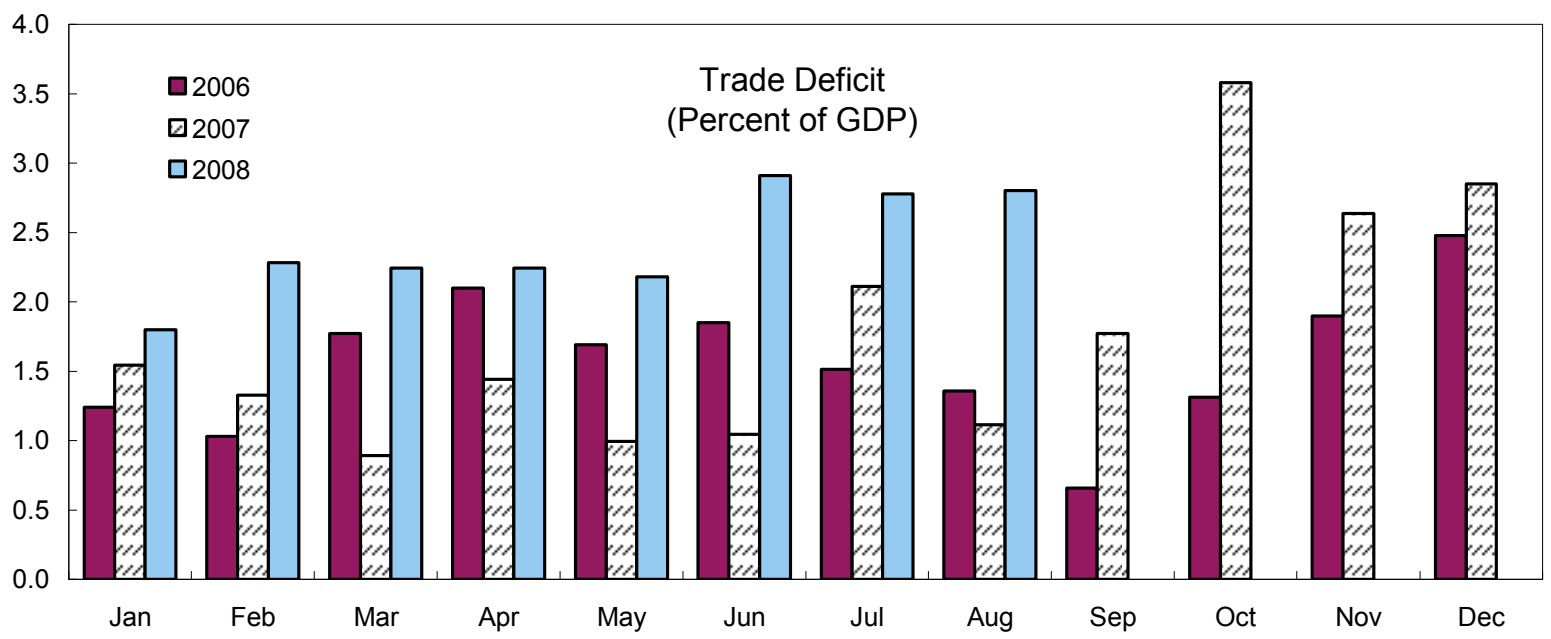

and falling private transfers.

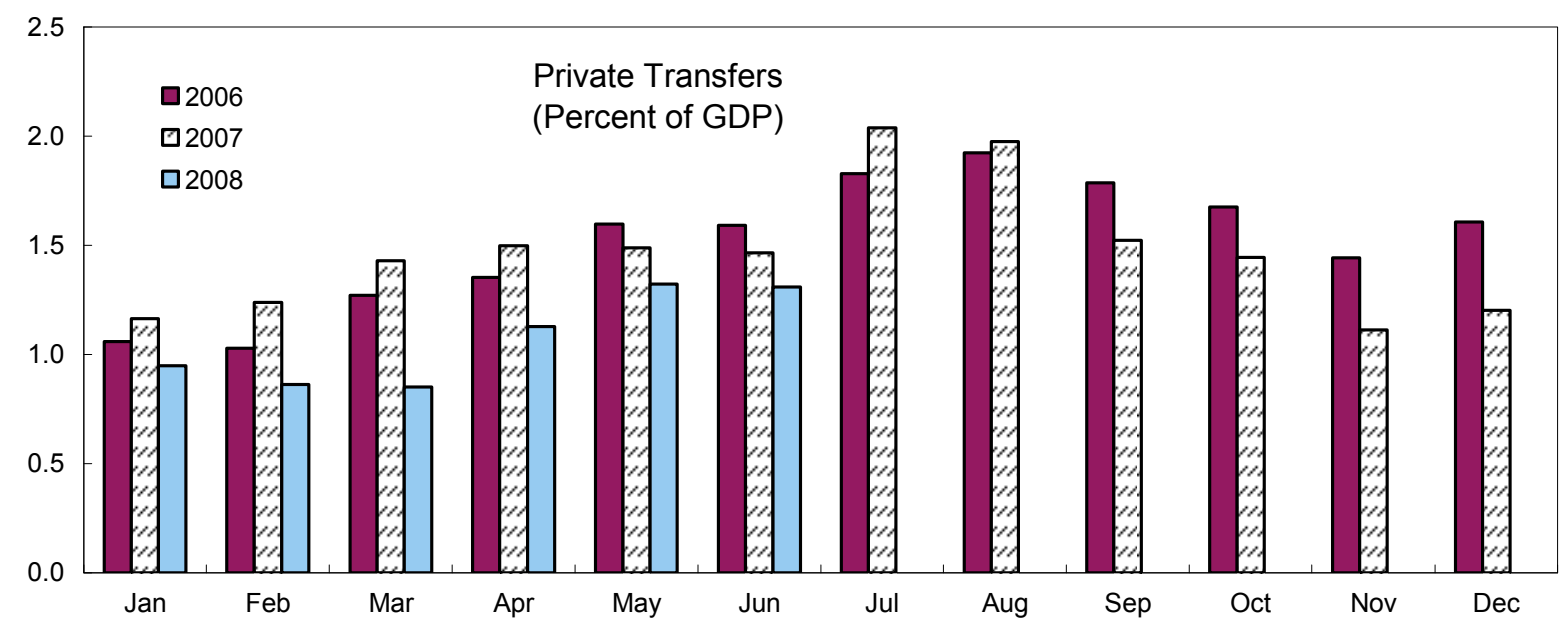

Sources: State Statistical Office; and NBRM; and IMF Staff estimates. 
Current Account and Trade Balance Developments in 2008 (projected, in percent of GDP)

\begin{tabular}{lccc}
\hline \multicolumn{2}{c}{ Change in Current Account } & \multicolumn{2}{c}{ Change in Trade Balance } \\
\hline Trade Balance & -6.7 & Non-energy & -4.5 \\
Private Transfers & -3.2 & Of which: Iron and steel & -2.9 \\
Telecom Dividend & -1.1 & Of which: Vehicles & -1.0 \\
& & Energy & -2.2 \\
& & Of which: Electricity & -1.6 \\
Total & -11.0 & & -6.7 \\
\hline
\end{tabular}

7. The trade deficit is projected to rise from 21 percent of GDP in 2007 to 28 percent in 2008. Main causes include:

- Rapid import growth. Imports of investment and intermediate goods, energy (due to increasing electricity demand since retail prices are frozen, shortfalls in domestic production, and higher world prices) and consumption have all grown rapidly. Increased exports of metals (though prices of nickel, a major export, have recently fallen sharply), and food (rebounding from last year's drought) only partly offset this.

- $\quad$ Private transfers fell more than 30 percent $y / y$ in the first quarter, reflecting uncertainties over inflation, June's elections, and Kosovo. With political stability returning, private transfers recovered somewhat in the second quarter.

- A severe deterioration in the terms of trade which, after improving by 4 percent in 2007, fell 7 percent in 2008.
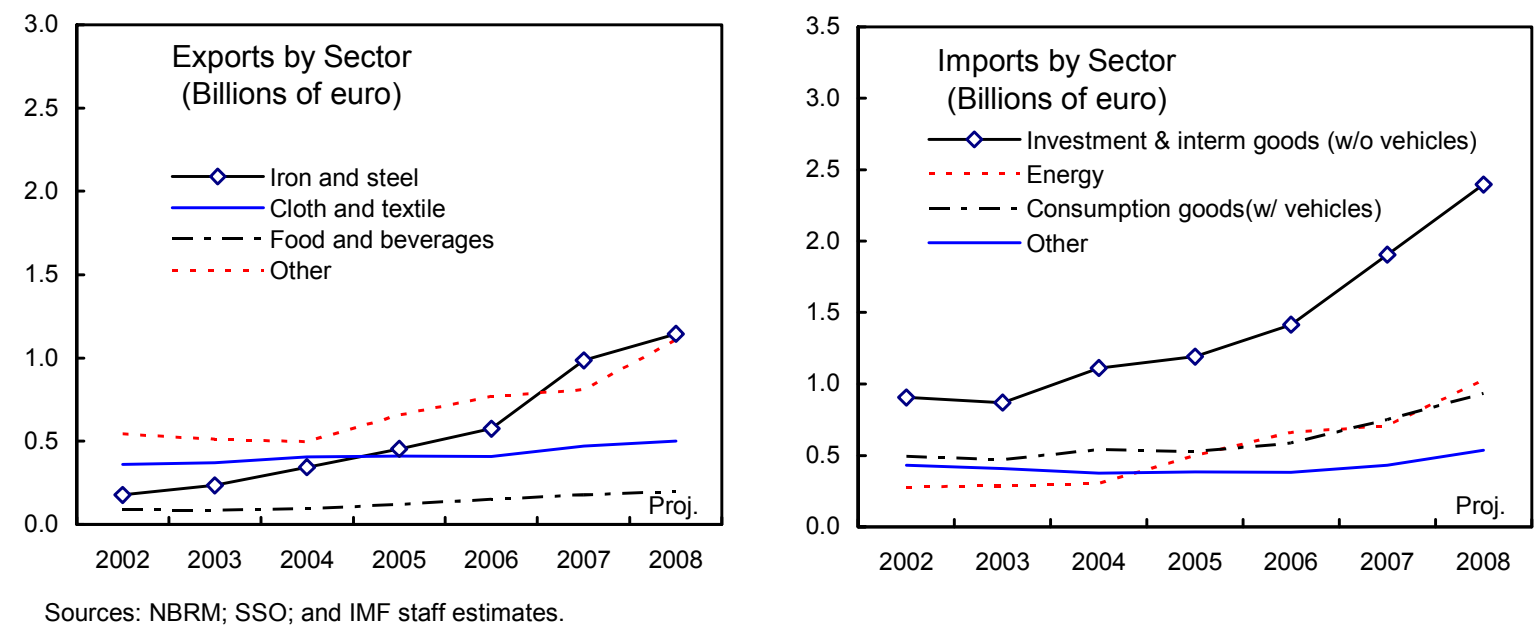

8. The sudden current account deterioration reflects some increase in investment, but mainly lower private savings. Investment is projected to increase by close to 20 percent, led by the government sector (SSO expenditure data through the first half of the 
year suggest the increase might be even larger). Saving is projected to fall by around

7 percent of GDP, financed by rapid household credit growth.

\section{Vulnerabilities have been growing, even before the international financial turmoil}

\section{External financing has been adequate but vulnerabilities were already growing ahead of the international financial turmoil (Box 1):}

- $\quad$ FDI has increased significantly and should cover over half of this year's current account deficit. However, more than half of this FDI represents parent company loans, which increase external debt and are easier than greenfield investment to reverse. Around 60 percent of the FDI is in non-tradables such as real estate and financial services, which may not generate the future current account surpluses needed to repay the FDI.

- $\quad$ The current account deficit may be understated, as the officially measured deficit treats all cash exchange of foreign currency into denars as current transactions. This treatment is correct for remittances and unrecorded exports, but not for capital inflows or conversion of mattress money. (Conversely at times of worsening confidence, residents converting denars into foreign currency mattress money would be misrecorded as a higher current account deficit, when really it is asset substitution. However, in this case vulnerability would still be increasing).

- $\quad$ External vulnerability indicators are deteriorating (Figure 5, Table 4).

- $\quad$ As in the region, a large portion of lending (around 55 percent) is either foreign currency linked or denominated. Banks transfer their currency risk into credit risk, as most borrowers are unhedged against a change in the denar-to-euro rate. This makes maintenance of the exchange rate anchor critical for financial stability. Interest rate risk is similarly transferred by banks to their customers, with rates on most credit products adjustable. 


\section{Box 1. Implications of International Financial Turmoil}

The staff is in close contact with the Macedonian authorities and financial sector representatives regarding potential spillovers from global developments.

The direct impact has been limited so far:

- $\quad$ Banks rely mainly on domestic deposits rather than international credit lines to fund lending. The banking system's loan-to-deposit ratio is well below 100 percent. Interbank lending is small (6 percent of GDP in 2007, largely overnight). Macedonian banks do not seem exposed to sub-prime lending overseas, and the domestic mortgage market is tiny (less than 3 percent of GDP).

- $\quad$ Foreign bank presence has increased, but few are globally active. The two most important mother banks - National Bank of Greece, which owns the largest Macedonian bank (Stopanska Banka) and Nova Ljubljanska Banka, which owns the third largest bank (Tutunska) - appear not to have incurred major losses in the international financial crisis.

- At $€ 20,000$, the deposit insurance level would traditionally be regarded as quite high (eight times per capita GDP, covering 75 percent of deposits).

- $\quad$ Pension funds have invested very conservatively, with foreign equities just 2 percent of assets.

- $\quad$ There have been no significant shifts from denar to euro deposits. The NBRM's reserves have recently increased slightly, but commercial banks' net foreign assets have declined.

- $\quad$ Portfolio inflows have dropped significantly (1 percent of GDP in 2008), contributing to sizeable stock market declines.

However, the indirect impact could grow. Lower world growth could worsen the current account deficit, through lower export demand (60 percent goes to the EU), falling export prices (metals are 40 percent of exports), or weaker private transfers (including remittances). Major metal producers have already started to reduce production and lay off workers. Against this, lower world oil prices would help. While increasing significantly in 2008, foreign direct investment could be sensitive to tighter international credit markets, and portfolio investment is declining. Liquidity pressures in the parents of foreign owned bank subsidiaries could lead to a withdrawal of credit lines.

In short, despite its relative insulation (until recently) from international financial markets, as a small, open economy, Macedonia would not be immune to a prolonged world recession. 
Figure 5. FYR Macedonia: Indicators of External Vulnerability, 2004-08

External debt increases have been driven by the private sector...

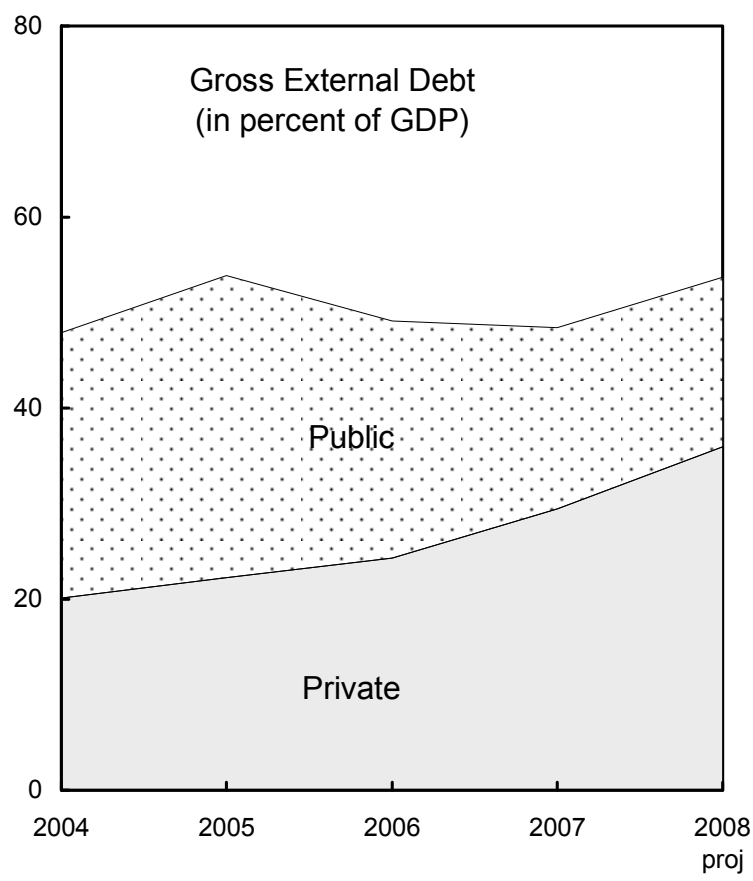

Reserves have flattened and reserve cover has fallen...

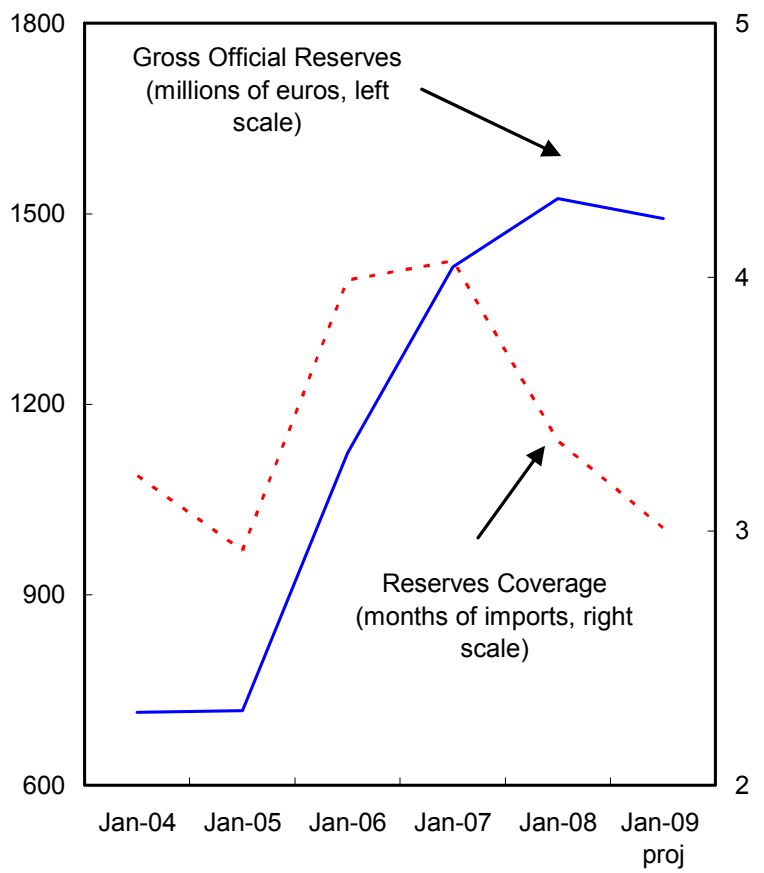

Sources: State Statistical Office; and NBRM. ...and maturities have become shorter.

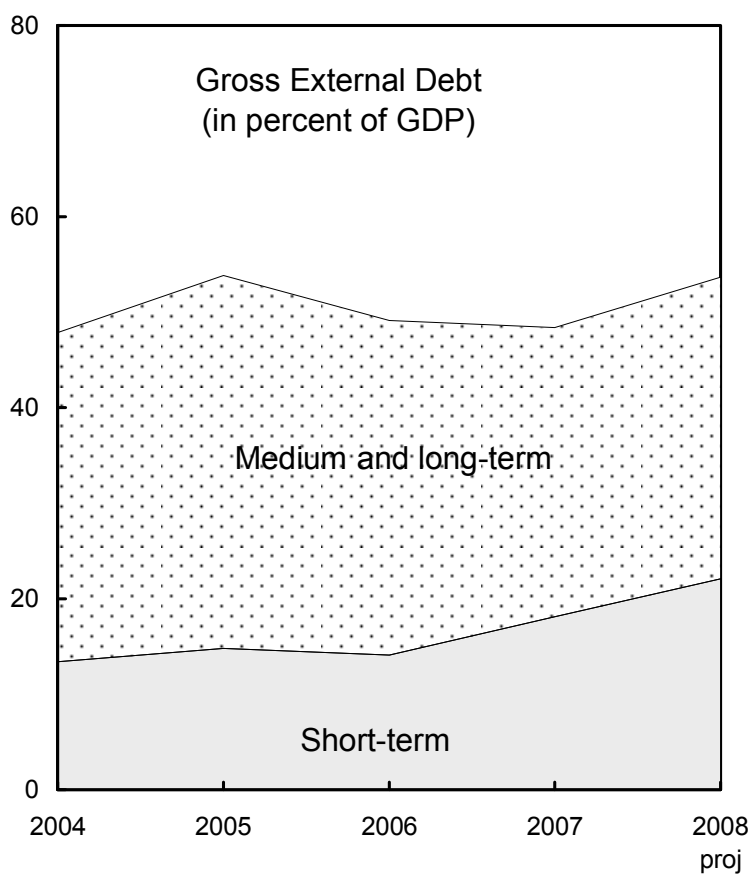

... while the spread between denar and euro deposit rates has risen.

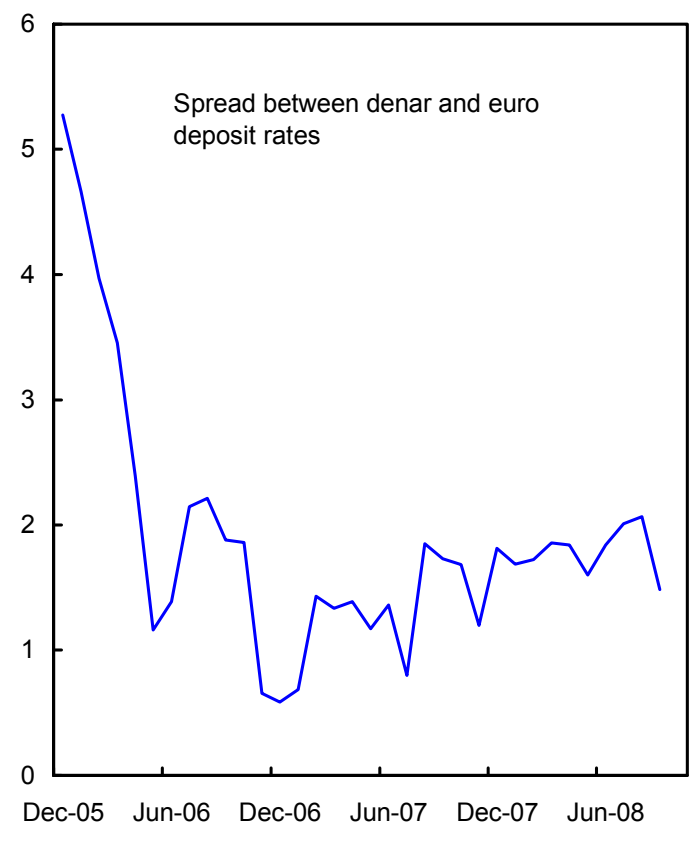




\section{The Policy Response}

\section{Against the background of increasing international financial turmoil,}

discussions focused on: (i) the appropriateness of the government's plans for continued fiscal expansion; (ii) the scope under the fixed exchange rate for monetary tightening; (iii) competitiveness; and (iv) structural reforms to raise potential output.

\section{A. Fiscal Policy}

\section{Fiscal policy has turned increasingly procyclical}

11. The government first took office in 2006, committed to reforming and lowering taxes. To pay for this it proposed cutting government spending by 2 percent of GDP and raising modestly the central government deficit to $1 \frac{1}{2}$ percent of GDP. In the event, spending increased, but revenue overperformance (and failure to execute spending) helped the government meet or surpass the deficit targets (Table 5). Rapid domestic demand growth (boosting VAT), a near-doubling of corporate income tax (paradoxical given the introduction of zero tax for reinvested profits, but perhaps explained by the government's elimination of the double-deduction for investment), improved tax administration (formalization of the shadow economy), and higher non-tax and capital revenues all boosted revenues.

\section{Box 2. Tax Policy Reform 2006-08}

- $\quad$ Lower personal and corporate income tax rates: flat 12 percent rate from 2007, 10 percent from 2008

- $\quad$ Zero taxation of reinvested profits, with no double deduction for investment from 2007

- $\quad$ Creation of technological and industrial zones with tax concessions (January 2007)

- $\quad$ Harmonizing minimum social insurance contribution bases (July 2007)

- $\quad$ VAT cut from 18 to 5 percent for computers, medicines, and public transport (October 2007)

- $\quad$ Introduction of a presumptive turnover tax for small businesses (January 2008)

12. While the central government budget has run a surplus of almost 3 percent of GDP in the first three quarters of 2008, fiscal policy has turned procyclical:

- $\quad$ Spending accelerated at the end of 2007 (especially on investment). Though the central government ran a 0.6 percent of GDP surplus in 2007, the fourth quarter had a $2^{1 / 2}$ percent of GDP deficit. Part of this spending was actually executed in 2008 .

- Pensions were increased 13 percent in January 2008, then another 7 percent in Julyeven though the pension system is in deficit. 
- Rather than letting the automatic stabilizers work and save revenue overperformance, July's supplementary budget increased government spending by 4 percent of GDP to almost 40 percent of GDP (Figure 6).

- $\quad$ Public sector wages were increased by 10 percent in October 2008, for the second year running.

- While the central government deficit planned for 2008 appears low, the overall public sector fiscal deficit including losses in the electricity sector (paid for by deferred maintenance and deterioration of the capital stock) is much greater (see the Selected Issues). Perhaps by as much as 1-2 percent of GDP.

\section{The new government intends further fiscal expansion}

13. Despite the worsening current account deficit and this year's strong growth, the new government plans further fiscal expansion. In its successful June re-election campaign, the government pledged to increase spending on public wages, pensions, agriculture, and education, and to cut social security contributions substantially (reducing minimum social contributions, and reducing rates from 32 to 22 percent over three years). Improved tax administration and a higher central government deficit of around 2 percent of GDP would finance this. However, the government explained to the mission that it intended to raise the deficit even further - to 3 percent of GDP in 2009 and 4 percent in 2011 - for additional infrastructure investment. Compared to the record under the Fund program of near budget balance, this plan would represent a paradigm shift in fiscal policy.

\section{The staff cautioned that this planned fiscal expansion could exacerbate Macedonia's medium-term external vulnerabilities (Table 6-Baseline Scenario):}

- $\quad$ The authorities' planned 4 percent of GDP fiscal deficit in the fourth quarter will boost growth slightly in 2008, but mostly increases the current account deficit (to around 14 percent of GDP) and worsens external vulnerabilities.

- Growth is assumed to slow to 4 percent in 2009 due to the international financial turmoil. Discussions during the mission centered on the attainability of the authorities' medium-term 6-8 percent output growth objective (see the Selected Issues). However, even this revised 4 percent projection is subject to considerable downside risk.

- Despite the widening of the fiscal deficit to 4 percent of GDP in 2011, the current account deficit is assumed to narrow gradually. This assumes that the previous terms of trade deterioration finally increases savings, and that past FDI boosts export supply. The government (but not the NBRM) argued the export response and current account adjustment would be more powerful. 
- $\quad$ However, external vulnerabilities increase significantly, with reserve cover falling below three months of imports, external debt rising from 48 percent of GDP at end2007 to more than 75 percent by 2013, and short-term external debt increasing significantly.

- The likelihood of a "sudden stop" and crisis would increase, particularly if the government's plans for substantial external financing (averaging 4 percent of GDP annually) fail. Abrupt current account adjustment would follow, with growth much lower than projected in Table 6 .

15. The staff recommended postponing these spending increases and to use fiscal policy to reduce external vulnerabilities (Table 7-Staff Alternative Scenario, Figure 7, see also Selected Issues):

- The staff proposed saving this year's revenue overperformance, and not execute the discretionary spending increases in the supplementary budget. This would produce a central government budget surplus (excluding electricity sector losses) of around $1 \frac{1}{2}$ percent of GDP. This would limit the current account deficit to 12 percent of GDP.

- In 2009 fiscal policy would be tighter than proposed by the authorities (so growth would be slightly lower, at 3 percent), but the automatic stabilizers give a fiscal stimulus of around $1 \frac{1}{2}$ percent of GDP.

- The current account deficit falls more rapidly, due to the tighter fiscal stance and stronger export response.

- External vulnerabilities are lower in this alternative scenario. Interest rates fall, private investment increases, and medium-term growth is higher, compared to the baseline.

16. Notwithstanding these vulnerabilities, the government reaffirmed its plans for further fiscal expansion. The government argued that past fiscal prudence and debt reduction had been at the expense of a much lower public capital stock. The government believed that its strong track record would continue to attract foreign investment, even though international financial conditions were more difficult. Given the worsened world economic outlook, the government argued that fiscal expansion could prove usefully countercyclical. However, during the Annual Meetings the government made clear that it stood ready to adjust its plans, should conditions deteriorate markedly. 
Figure 6. General Government - Regional Comparison, 2008

(Percent of GDP)
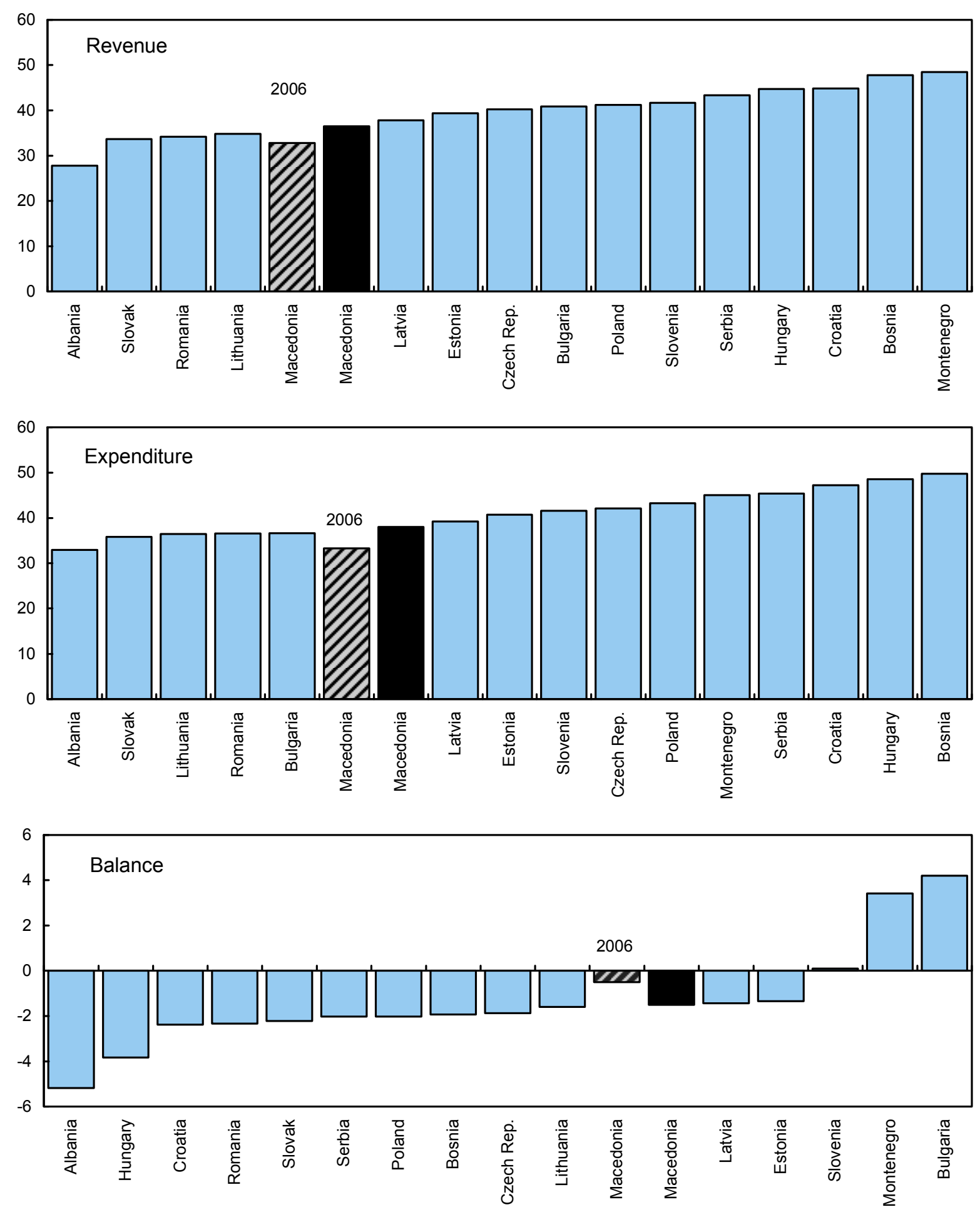

Source: WEO. 
Figure 7. FYR Macedonia: Medium-Term Scenarios, 2007-13
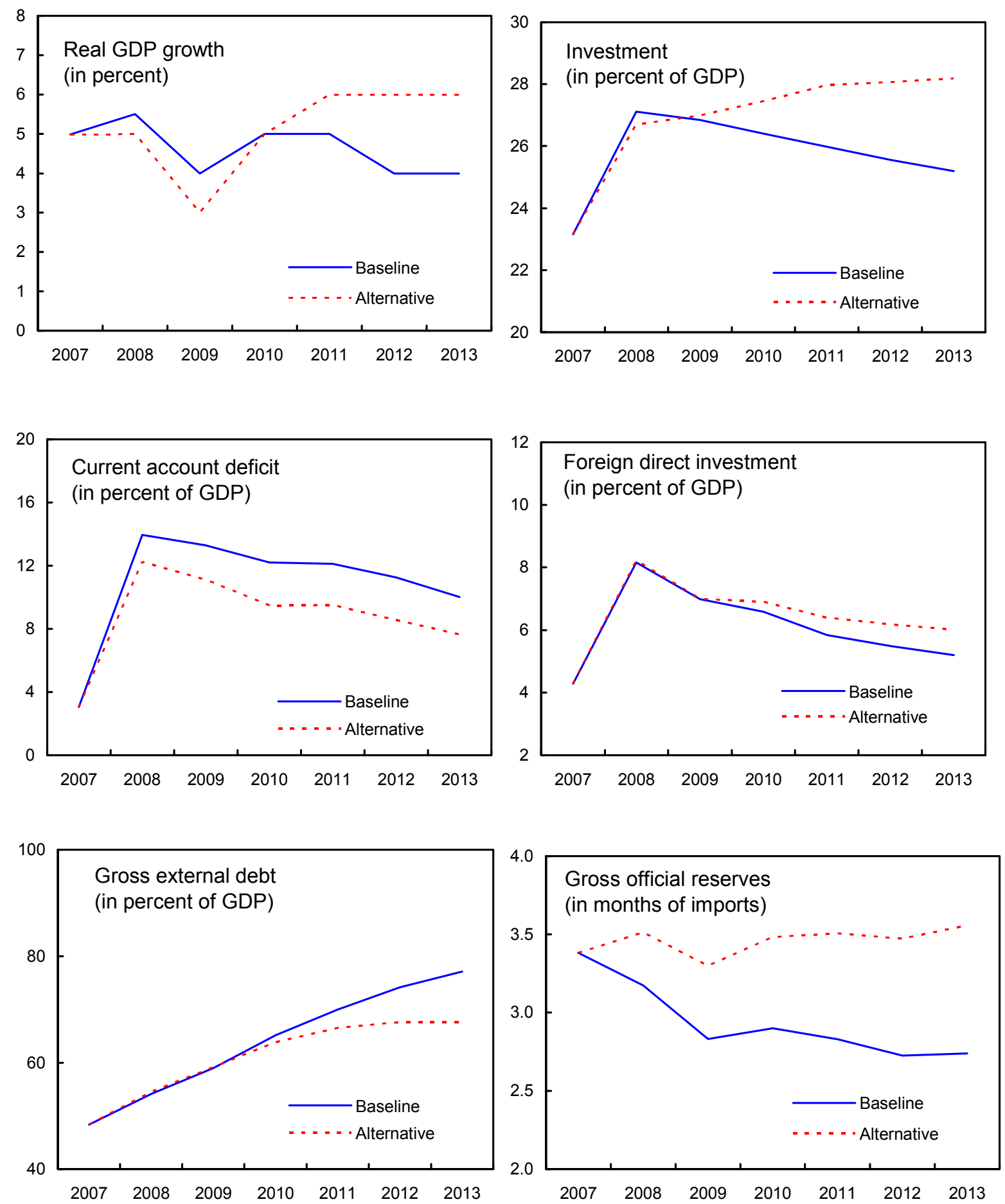

Sources: State Statistical Office; Ministry of Finance; NBRM; and IMF staff estimates. 


\section{B. Monetary and Financial Sector}

\section{After easing through 2007 the NBRM has started to tighten monetary policy}

17. Monetary policy eased for much of the program, driven by capital inflows and reserve accumulation under the peg (Figures 8-9, Tables 8-9). From 2005 to 2007, gross reserves increased by $€ 400$ million ( 6 percent of GDP). The NBRM issued central bank and treasury bills to sterilize, but this attracted further inflows. With limited ability to resist these forces, and facing pressure from the Ministry of Finance, central bank rates fell below 5 percent, low by historical standards and only a little above ECB rates.

\section{Despite expanding rapidly, the Macedonian banking system remains small} compared to the region, with credit only around 40 percent of GDP. Banks with majority foreign ownership have increased their market share to more than 85 percent of total assets, versus 50 percent at end-2006 (however, only one of these banks is active globally). With increasing bank competition, commercial lending rates fell below 10 percent (real rates were even lower) and credit growth in 2007 increased to almost 40 percent.
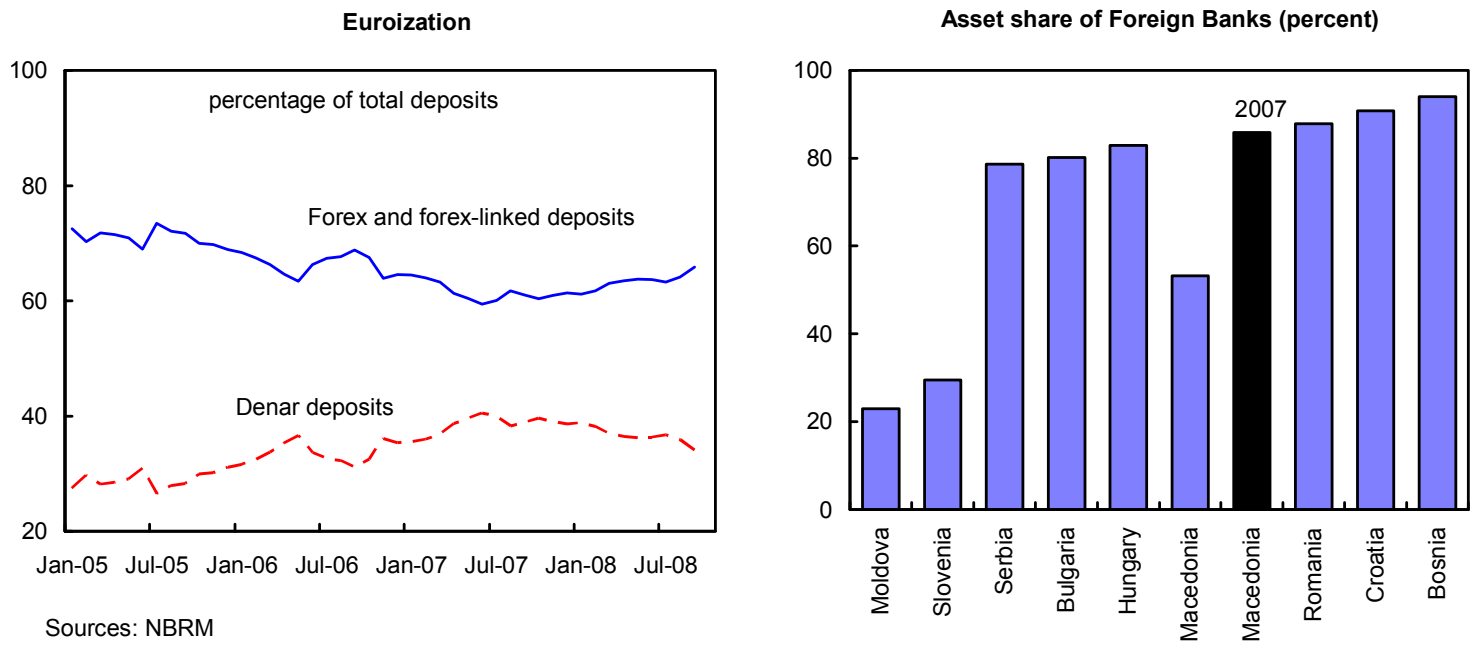

Data for 2006, unless indicated otherwise. Sources: NBRM; and EBRD.

19. During 2008, the NBRM started to tighten monetary policy. The NBRM switched to a volume tender (to increase the signaling role of its policy rate) and gradually raised central bank rates to 7 percent. In March it raised capital adequacy requirements for overdraft and credit card loans. Given uncertainties over the transmission mechanism, in June it also introduced quantitative controls, requiring banks to place low interest deposits if their household credit growth was set to exceed 40 percent by end-year. In addition, the base used for determining reserve requirements was broadened. 
Figure 8. FYR Macedonia: Financial Market Developments, 2006-08

The NBRM increased rates in 2008. While deposit rates have partly followed, increased bank competition has pushed lending rates lower.
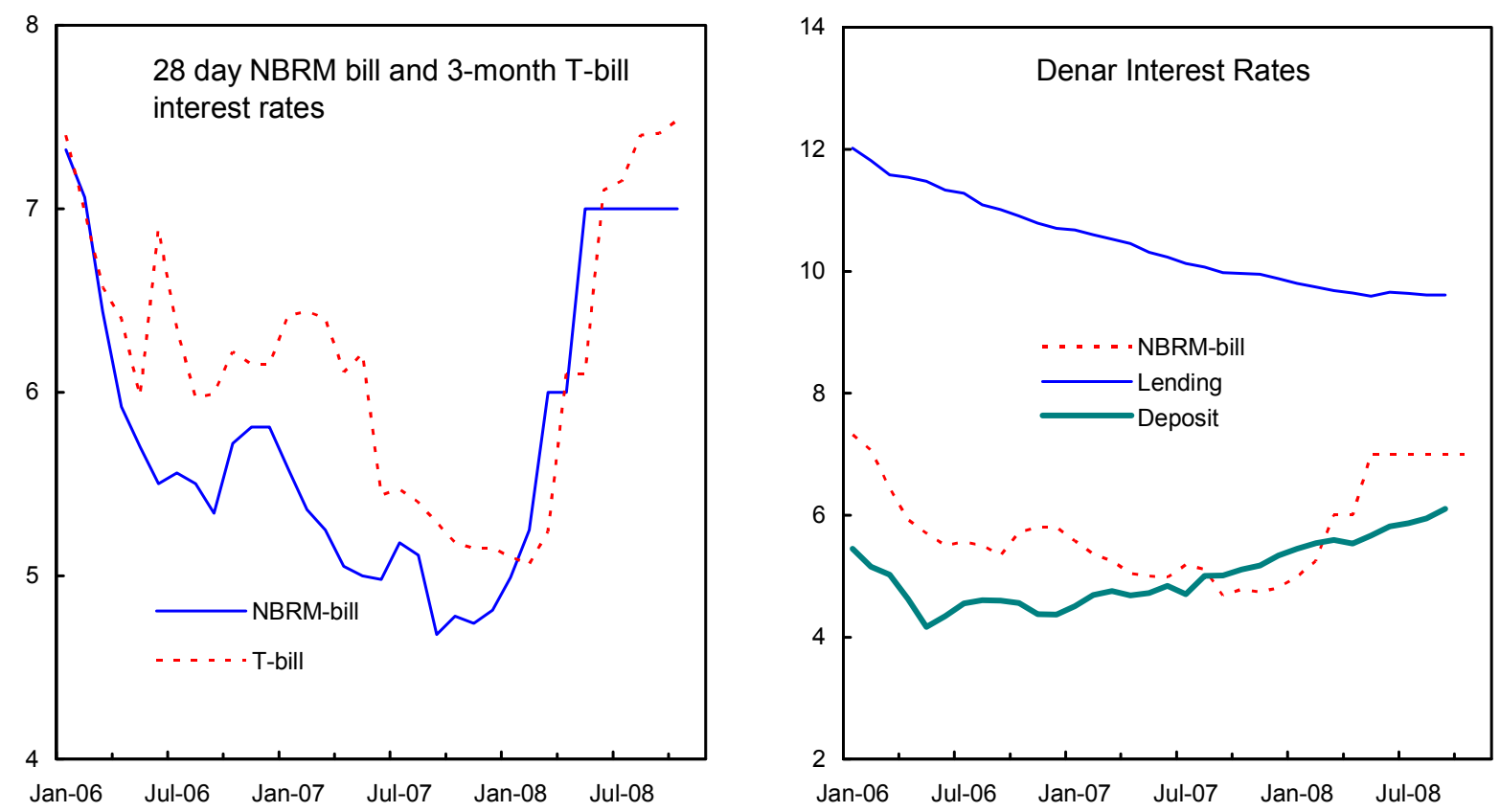

International financial turmoil has had limited impact on the real economy, but its impact can be seen in wider eurobond spreads and sharp declines in the stock market.
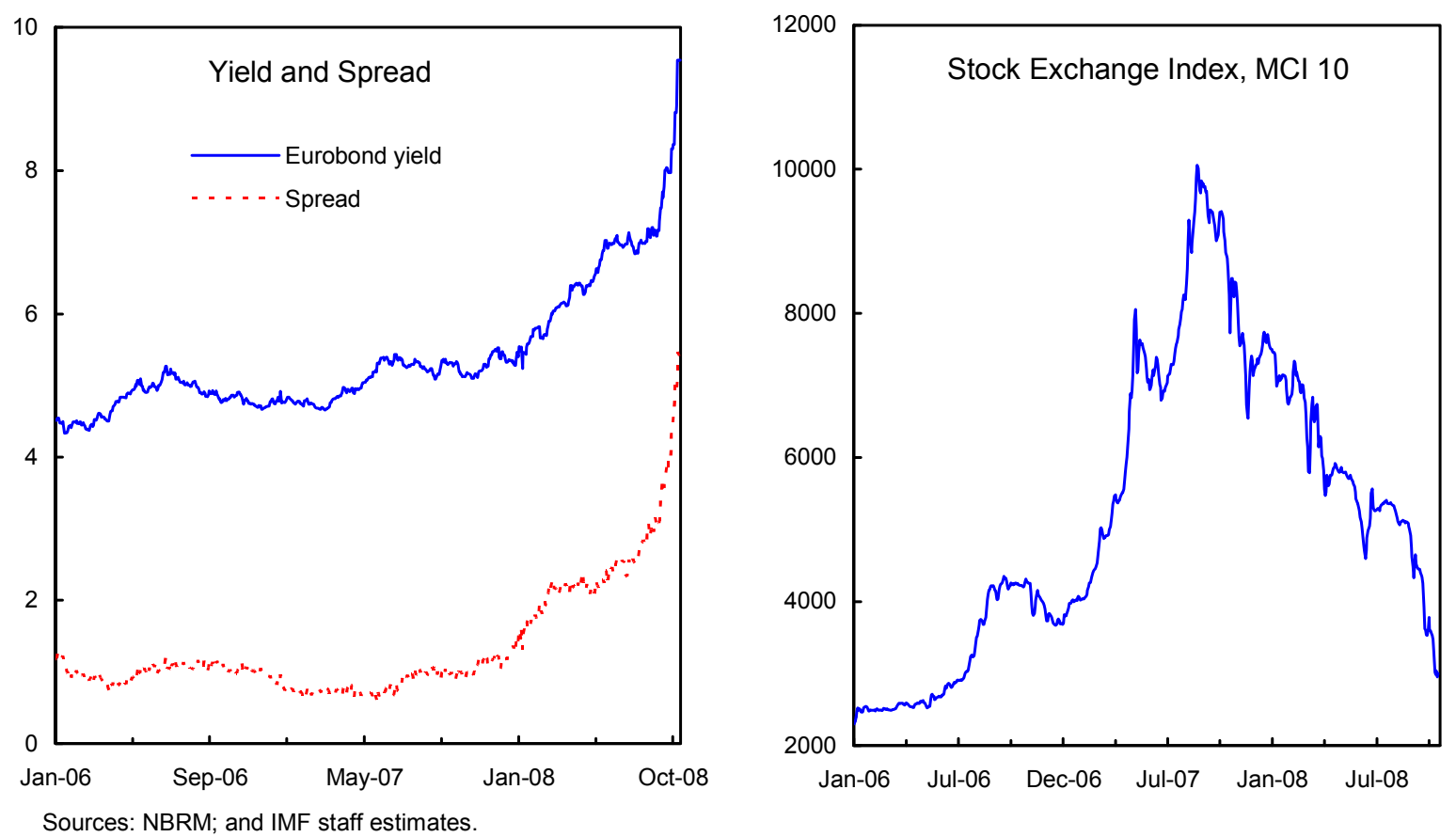
Figure 9. FYR Macedonia: Credit Developments, 2004-08

The stock of credit remains relatively low...

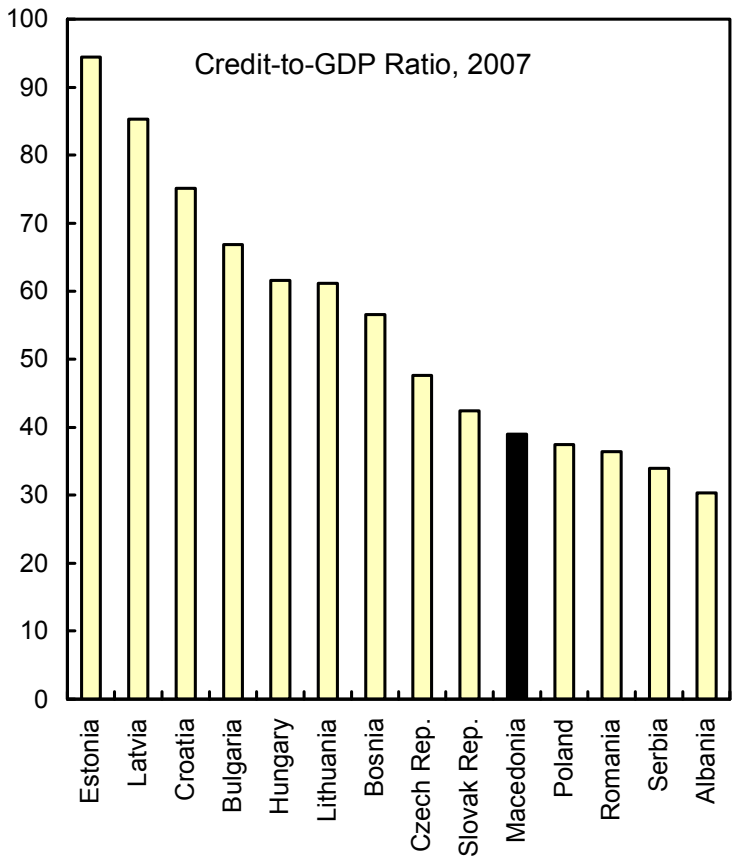

Rapid credit growth has been driven by households.

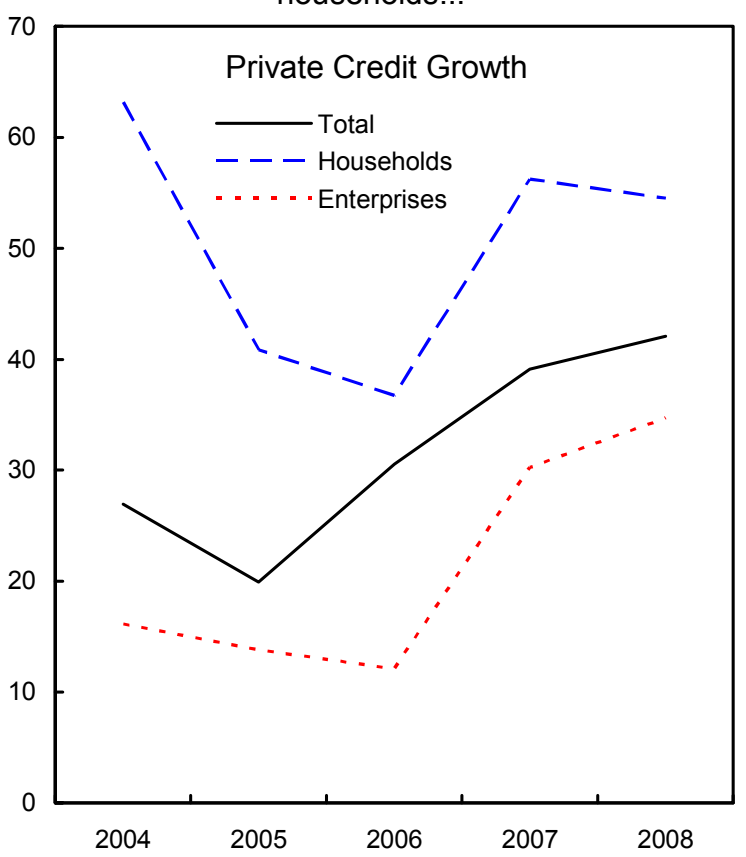

...but has increased rapidly.

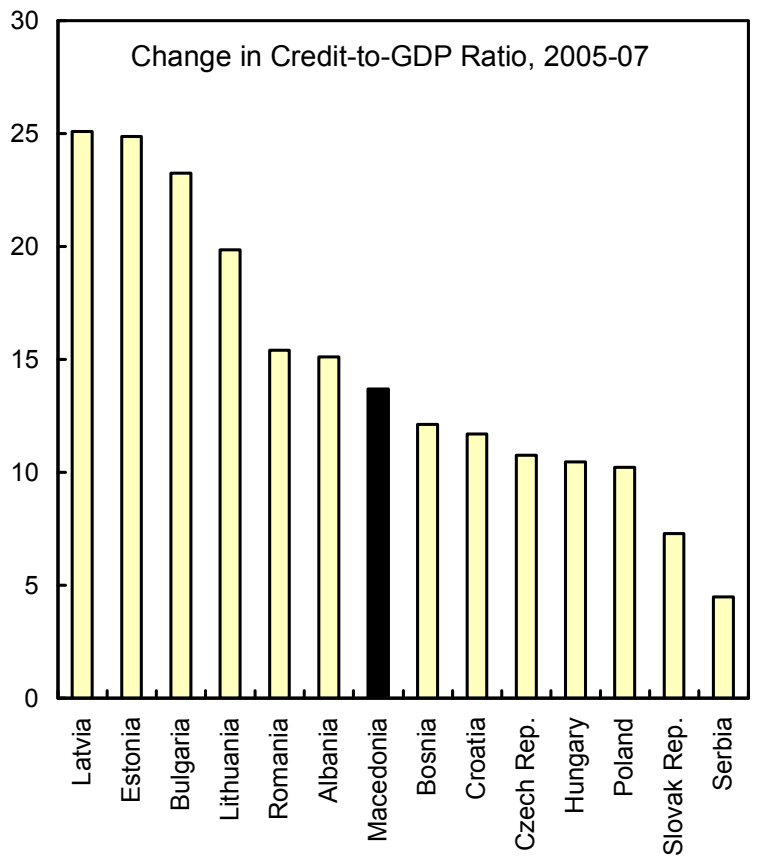

....and financed by banks drawing down their net foreign assets.

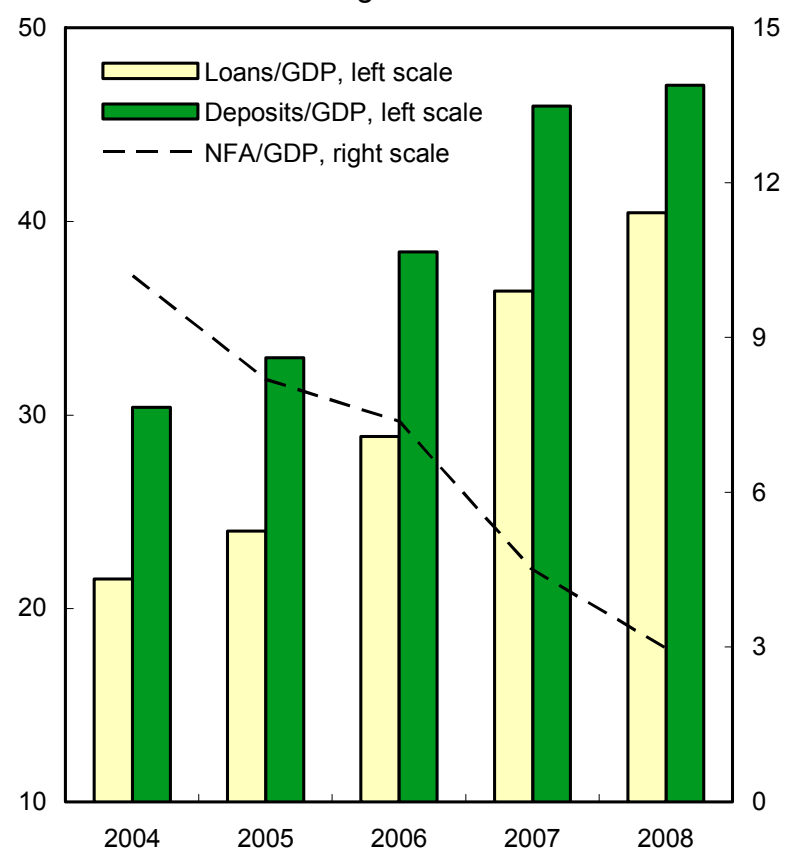

Sources: NBRM; and IMF staff estimates. 


\section{Increased vulnerabilities mean further action may be required}

20. The mission welcomed the NBRM's actions but recommended further interest rate increases to slow credit growth. Despite the fixed exchange rate, the central bank now had room to raise interest rates, since international reserves had leveled off. Commercial banks had increased deposit rates in line with higher NBRM rates. Lending rates had fallen, but this reflected increased competition and that central bank rates had been too low to be binding. If increased sufficiently, higher central bank rates should eventually cause commercial banks to raise lending rates. However, while the NBRM was open to taking further action should credit growth not slow sufficiently, the government opposed monetary tightening.

21. The staff suggested replacing the NBRM's quantitative controls when they expire in January. The effectiveness of controls had been undermined, since many banks had decided to pursue market share through rapid credit growth, by paying the penalty of compulsory low interest rate deposits. That said, if foreign credit lines dry up credit growth could fall rapidly. The mission recommended replacing the controls with higher reserve requirements and increased capital requirements for riskier loans (less distortionary than the current bank-by-bank controls, and would also help protect credit quality). The mission also encouraged strengthened reporting requirements on leasing companies, to prevent evasion of the controls.

\section{The banking system seems relatively healthy, though rapid credit growth and court challenges to the NBRM's enforcement powers are of concern (Tables 10-11,} Figure 10). Stress tests for the Financial Sector Assessment Program (FSAP) update indicate the banking system is sufficiently capitalized to withstand a wide range of shocks, but recent rapid increases in credit need to be carefully monitored (see the accompanying Financial System Stability Assessment for details). The authorities should also develop contingency plans for responding to crises. Although the 2007 Banking Law substantially strengthened the legal and regulatory framework, recent Constitutional Court rulings limit the NBRM's ability to resolve problem banks and to ensure that bank owners are "fit and proper". The authorities agreed to develop new legislation, consistent with the Constitution, that restores these essential powers.

\section{The peg remains appropriate as long as fiscal and monetary policies are supportive}

23. Risks to future external stability are increasing (Tables 12-14). The current account deficit is not sustainable at this year's projected level, with estimates suggesting modest overvaluation - although these are subject to considerable uncertainty. However, the size and speed of the current account deterioration despite little real exchange rate movement suggests exchange rate policies are not the cause, though these could become an issue unless there is macroeconomic policy adjustment. As outlined in the staff scenario (Table 7), a 
combination of policy tightening, structural reforms, and sustained strong foreign direct investment (but which is export-oriented) could maintain external stability. Risks on the capital account are also growing, where projections suggest that significant new external borrowing will be needed to stabilize reserve cover. Maturities are also likely to shorten.

\section{The fixed exchange rate regime has been appropriate, but its maintenance}

depends on supportive policies. Macedonia is a small open economy, with trade concentrated towards the Euro area, incomplete financial market integration, and partial euroization. This makes fixed exchange rates appropriate (Country Report 06/344). The fixed exchange rate is also a valuable nominal anchor. However, unless structural reforms are able to attract sustained FDI (at a time of increased international financial turmoil) or the terms of trade improve, then macroeconomic policies may need to adjust to protect the peg, even if sometimes this means sacrificing internal balance.

\section{Box 3. Assessment of Competitiveness and External Stability}

The assessment of competitiveness and external stability is mixed.

On the plus side, export growth has been strong (though not well-diversified), structural competitiveness indicators are improving, and (until recently) unit labor costs and the real exchange rate have shown competitiveness gains.

However, formal assessment of the real exchange rate gives diverse results. The simple PPP approach shows undervaluation, while CGER-based assessments suggest some overvaluation:

This assessment is subject to considerable uncertainty. It is difficult to analyze "the" equilibrium real exchange rate in a rapidly evolving transition economy. There are also significant uncertainties over projections of private transfers, the world economic outlook, and coefficients from econometric estimates. 
Figure 10. FYR Macedonia: Banking Sector Developments, 2004-08

Banks have continued to expand their activity...

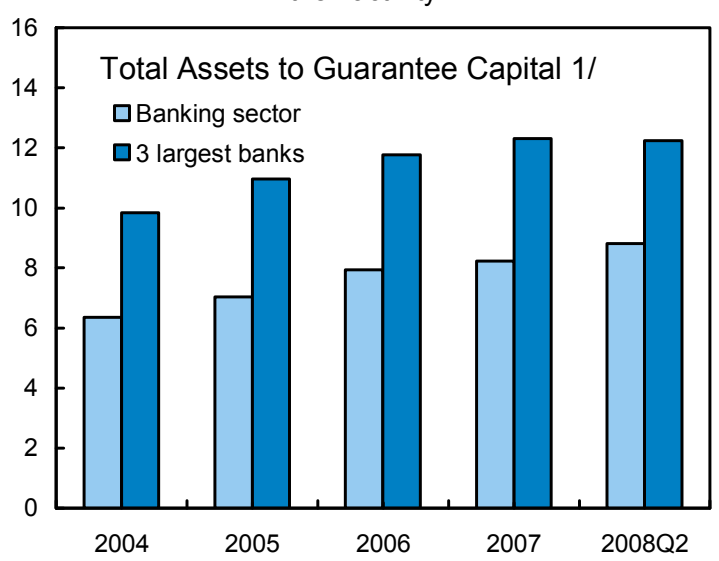

While the ratio of nonperforming loans has fallen...

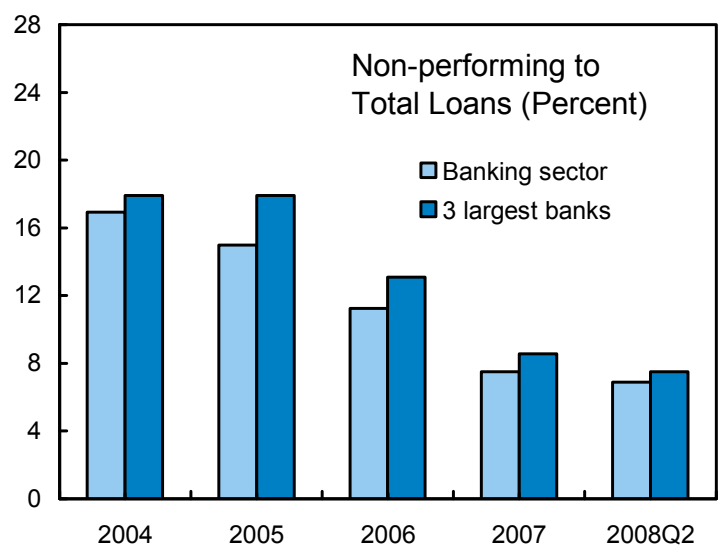

Banks have strengthened their profitability...

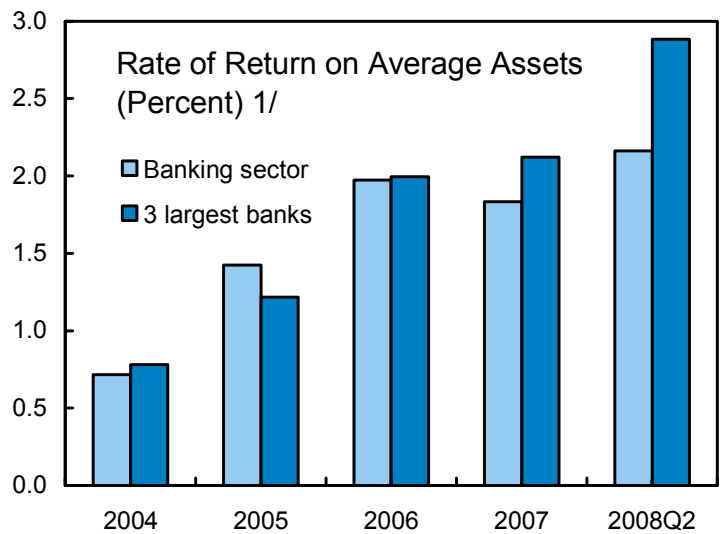

Sources: NBRM; and Fund staff estimates.

$1 /$ Total assets include off-balance sheet items.

2/ Adjusted for unallocated provisions for potential losses.
Risk-adjusted asset productivity has fallen slightly...

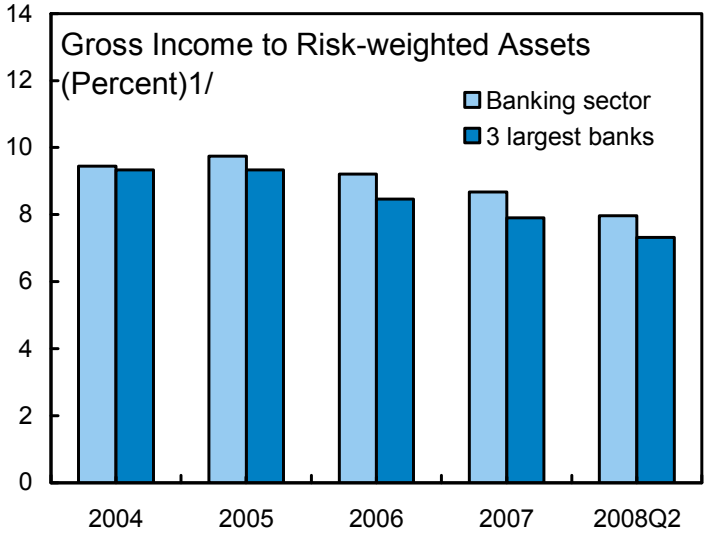

...the household share of non-performing loans has risen.

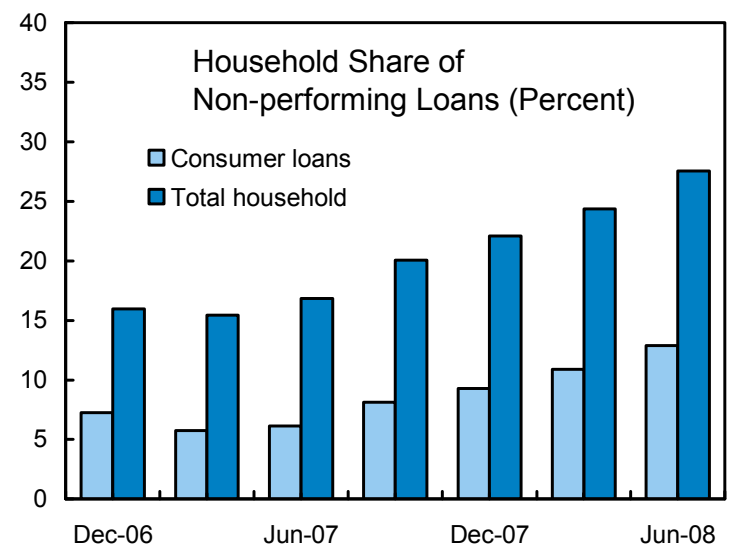

... and capital adequacy, though declining, remains adequate.

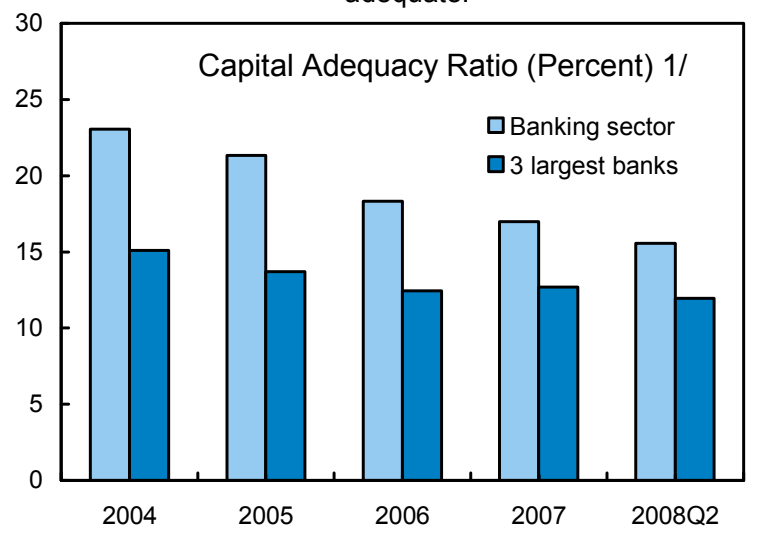


Figure 11. FYR Macedonia: Exchange Rate Assessment, 2000-08

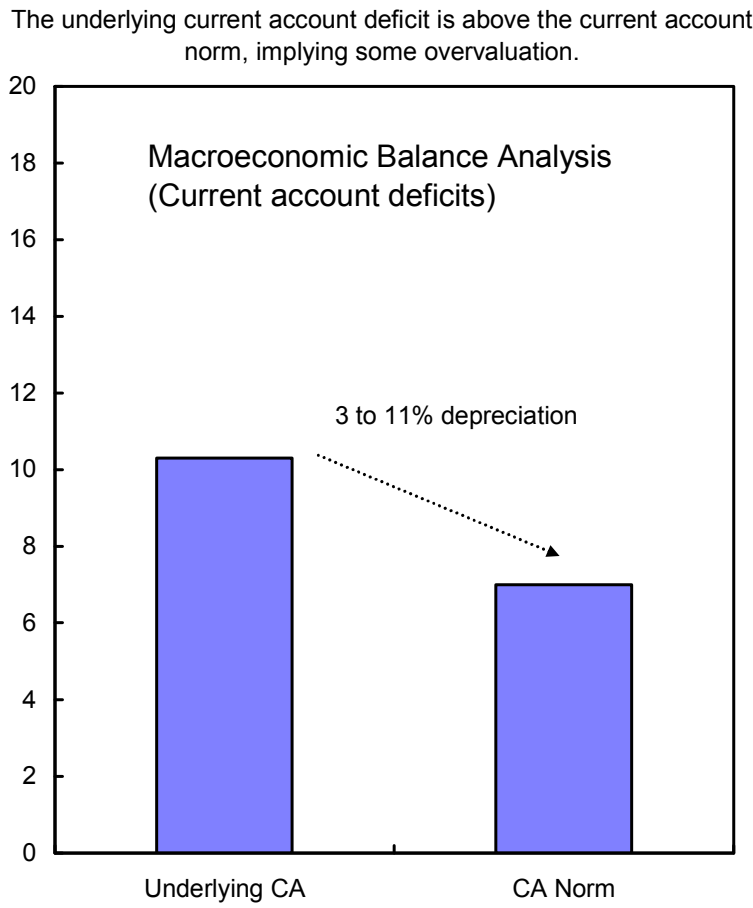

Estimates of the equilibrium real exchange rate suggest recent shift to modest overvaluation.

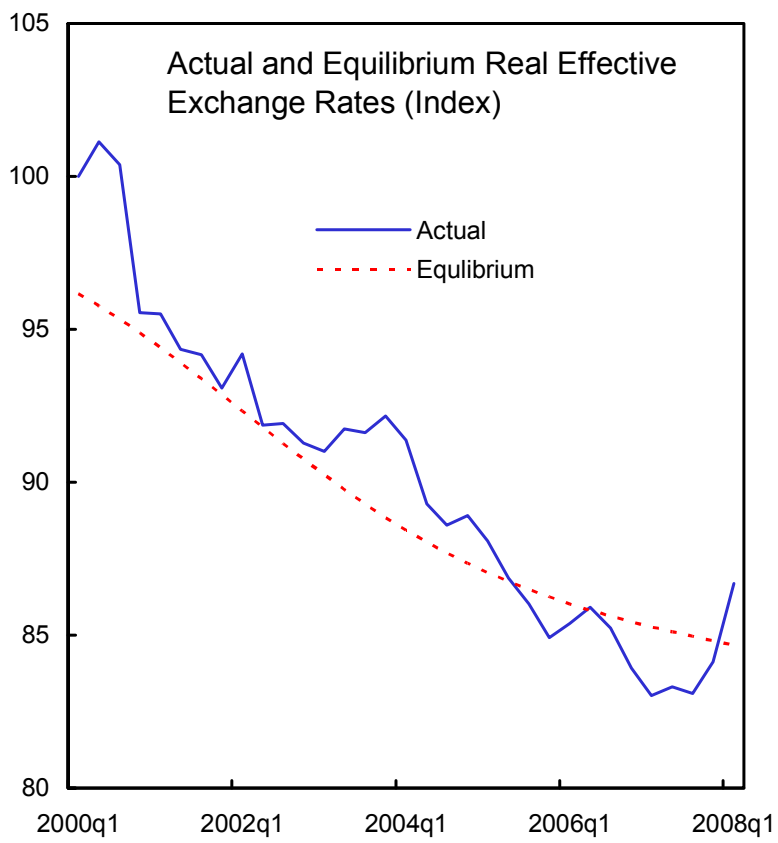

Stabilizing the net IIP at 2008 level (within the range of peer countries) would require reduction in Macedonia's CAD

Macedonia's export market shares have been increasing but are sensitive to ToT movements.
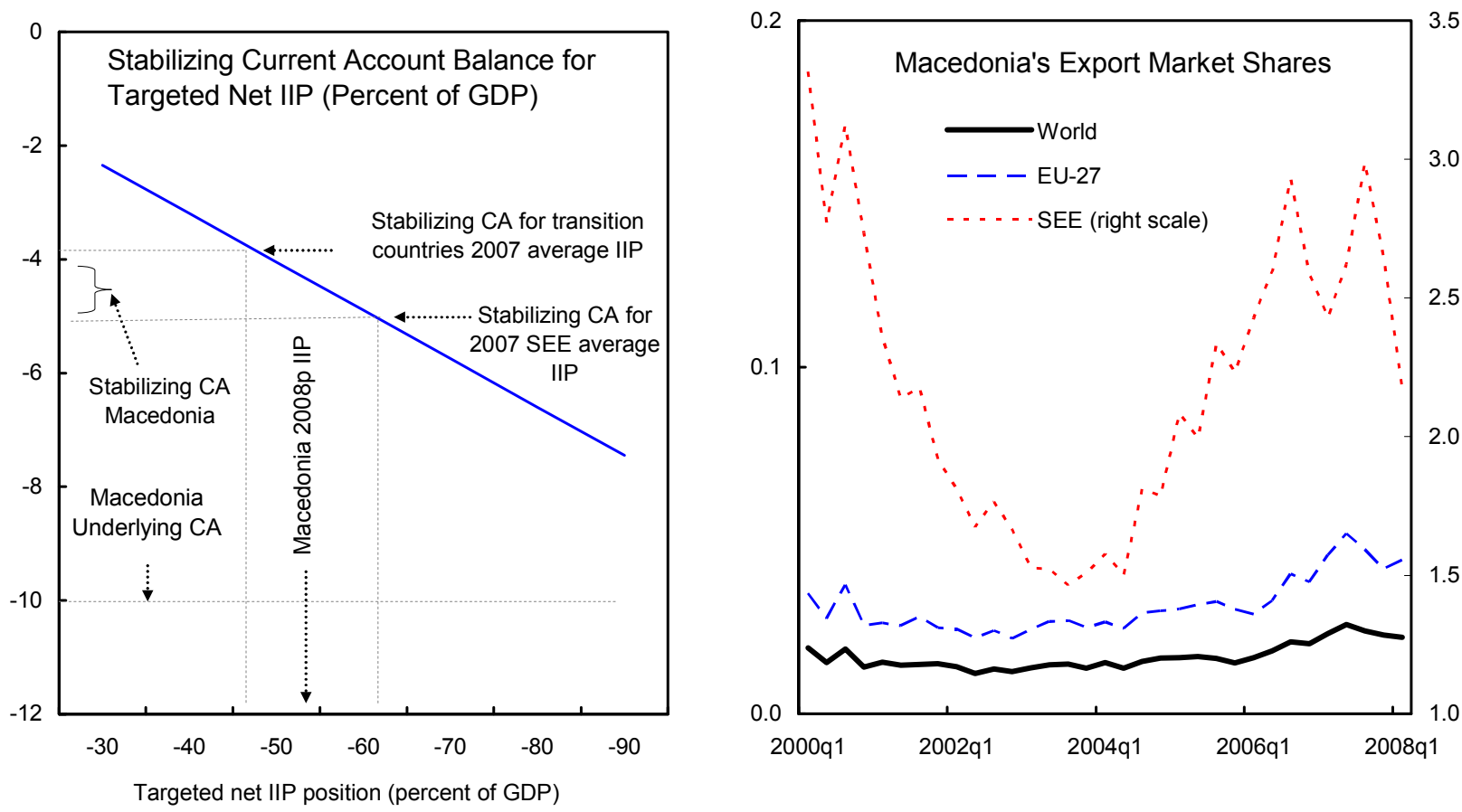

Sources: WEO; IFS, DOTS; and IMF staff estimates.

Note: The current account norm is estimated using coefficients from Imam and Minoiu (2008) and Rahman (2008). The underlying current account $=$ medium-term $(2013)$ projection. The IIP-stabilizing current account position assumes potential growth of 5 percent and 3 percent inflation. 


\section{Structural Reform}

25. The fixed exchange rate makes structural reform critical for competitiveness and raising potential growth. The new government's strong majority makes it well placed to accelerate these reforms.

26. The mission welcomed the government's plan to reduce minimum social contributions, provided the fiscal cost is offset. Reducing minimum contributions will encourage the low paid to enter the formal economy. While a useful first step, the mission urged the government to go further and abolish minimum contributions altogether. The mission strongly commended the government for preparing to include food and transport allowances as taxable income. This would remove a source of distortion and tax avoidance, and could help finance lower labor tax rates.

27. However, the government's more ambitious plan to cut rates for all workers by 10 percentage points over three years will cost more than $2 \frac{1}{2}$ percent of GDP. The mission cautioned that this will worsen the social funds' already weak financial condition. It could lower standards of health services today and result in inadequate future pensions. Unless compliance improves dramatically, additional measures will be needed to pay for the fiscal costs.

28. The mission urged the government to improve public expenditure management, to ensure that the planned increase in public investment was not wasted. Investments should be subjected to cost-benefit analysis, integrated into the annual budget, and future operating and maintenance costs included. Instead of repeatedly introducing supplementary budgets with new spending, more time should be spent improving the original budget, then ensuring its implementation.

29. The government has greatly strengthened tax administration. Creation of a large taxpayer office has improved compliance and simplified tax preparation for firms, while recent Public Revenue Office law amendments will improve staff flexibility. The authorities also intend to harmonize the bases for social security contributions with the personal income tax, and to make these depend on gross rather than net wages. This will ease the computation burden and simplify tax administration, and has the potential to raise additional revenues. The mission strongly supports this ambitious reform.

30. The business environment is also improving (Table 15). The authorities have implemented a 'regulatory guillotine' (abolishing unnecessary regulations) and expanded coverage of the real estate cadastre. Time for business registration was cut from five days to four hours, and tax rates lowered. As a result, Macedonia recorded excellent improvements in the World Bank's 'Doing Business' surveys. However, privatization has slowed (missing 
opportunities to bring in outside investment and expertise) and protracted disputes with foreign investors have complicated business conditions in the energy sector.

31. Despite these improvements, electricity sector distortions have worsened, increasing the trade and budget deficits (see Selected Issues). The government took the difficult step of ending electricity subsidies for large-users, and making them pay import prices. This saved the budget 2 percent of GDP. However, domestic retail prices have been kept at low levels. Domestic production shortfalls due to low rainfall and insufficient maintenance have increased the electricity trade deficit to almost 5 percent of GDP. The mission urged the government to respect the independence of the energy regulatory commission, especially when setting prices, so that electricity firms could cover costs. The government also needs to develop measures to protect the poor from electricity price increases.

\section{Staff Appraisal}

32. Expansionary macroeconomic policies, improvements in the business climate, and a surge in FDI have boosted growth. Though there is substantial room for catch up, living standards have improved and employment have increased.

33. While growth has improved, macroeconomic vulnerabilities have increased. Inflation reached double digits this year, but now has started to decline due to lower food prices and the exchange rate anchor. However, the current account deficit has widened dramatically to a projected 14 percent of GDP. The real exchange rate may have become somewhat overvalued. However, worsening terms of trade, and rapid increases in pensions and public sector wages, public investment, and household credit have been the main causes of the current account deterioration.

\section{Recent international financial turmoil will increase external vulnerabilities.}

While the direct impact of the turmoil on Macedonia's financial sector has been limited, the indirect impact is growing. Export demand has started to fall, with the metals sector laying off workers. Potentially lower FDI and portfolio inflows (due to tighter international credit markets) and weaker remittances (driven by lower world growth) could create additional balance of payments pressures.

35. Macroeconomic vulnerabilities could have been reduced by letting the automatic stabilizers work. The government should have acted countercyclically by saving this year's strong revenue overperformance, even if this meant running a central government budget surplus. Instead, the government's decision to raise spending by almost 4 percent of GDP, if implemented, will add to domestic demand and worsen the current account deficit.

36. Plans for further increases in the fiscal deficit ignore these growing macroeconomic vulnerabilities and should be reconsidered. Increasing the central 
government deficit to 3 percent of GDP in 2009, then to 4 percent by 2011, will increase pressure on inflation and the current account.

37. Monetary policy should be in line with the fixed exchange rate regime. Despite the constraints of the exchange rate peg, the central bank could have raised interest rates more aggressively earlier this year, given the slowdown in reserve accumulation. This might have reduced credit growth and lessened the current account deficit deterioration. Credit controls should be replaced when they expire in January by raising reserve requirements, or increasing capital requirements on riskier loans. Looking ahead, higher interest rates would also help slow credit growth, though the international financial turmoil may also have this effect. In either case, the priority of monetary policy should be to protect the exchange rate.

38. Macroeconomic policy adjustment would support the fixed exchange rate. Preannouncing expansionary fiscal deficit targets over the medium term is risky, given that fiscal policy needs to be ready to respond flexibly to defend the peg. Reversing this planned fiscal expansion would reduce external vulnerabilities, and lessen the risk of a "sudden stop" in the event of an unanticipated shock. The central bank would then have less need to increase interest rates, so private investment would be higher. While projections of external sustainability are subject to far greater uncertainty than normal, the government should be ready to tighten fiscal policy should risks to external stability increase.

39. Significant progress has been achieved since the 2003 FSAP in improving banking supervision. Implementation of the FSAP update recommendations would strengthen financial sector supervision, and address gaps in nonbank financial sector supervision. However, residents' unhedged foreign exchange borrowing remains a significant vulnerability. The authorities should develop contingency plans in case of spillovers from the international financial turmoil. They should also find a way to restore the NBRM's supervisory powers that were recently ruled unconstitutional.

40. Structural reform is critical to sustained rapid economic growth, and to economic convergence. The government's efforts to improve the business climate, encourage foreign direct investment, and cutting labor taxes to stimulate employment will increase potential growth. However, the government should reinvigorate its privatization plans, address the budgetary and trade deficit problems caused by artificially low electricity prices, and strengthen the social safety net to protect the poorest electricity consumers.

41. In sum, while the authorities have reformed the economy and boosted growth, increasing external vulnerabilities could put these gains at risk, and call for reconsidering plans for fiscal expansion, and for accelerating structural reform. Since the Stand-By Arrangement has expired in August 2008, it is recommended that the next Article IV consultation with FYR Macedonia take place in 12 months 
Table 1. Effectiveness of Fund Policy Advice

\section{Macroeconomic Policy}

- $\quad$ For much of the program, the main objectives of macroeconomic stability, boosting growth, and reducing external vulnerability were achieved.

- $\quad$ Growth averaged around 5 percent, and though inflation picked up in late 2007 through 2008 this is due mainly to food and energy price shocks, so should prove temporary.

- International reserves increased significantly in 2006 and 2007, boosting confidence in the peg and allowing significant interest rate reductions.

- However, the sharp deterioration in the current account deficit in 2008-though largely covered by increased FDI-points to increased external vulnerability.

\section{Fiscal Policy-maintaining a low central government deficit}

- $\quad$ At first the government followed Fund advice and even out-performed the program's deficit targets, running a small 0.6 percent of GDP deficit in 2006 and a 0.6 percent surplus in 2007.

- However, with inflation increasing and the threat of a widening current account deficit, in early 2008 Fund staff advised saving the revenue overperformance, and running a surplus of around 1-2 percent of GDP.

- $\quad$ The authorities instead increased spending to try to meet this year's 1.5 percent of GDP deficit target, pointing to the need to raise public investment and that government debt ratios are low.

\section{Tax Administration-improving revenue collection}

- $\quad$ The partnership between the government and the FAD-Dutch tax administration reform project has been successful. Implementation of the reforms has been impressive, and government ownership very strong.

- In part because of these reforms, the share of revenues in GDP increased by around 1 percentage point, despite substantial cuts in tax rates.

- $\quad$ Creation of a large taxpayer office has strengthened compliance and improved taxpayer services, while recent amendments to the Public Revenue Office (PRO) law will improve flexibility in rewarding performance.

- The authorities have now brought forward a critical element of these reforms-integrating collections from the three separate social funds into the PRO-to January 2009. This will greatly simplify the collection (and payment) of taxes and social contributions.

\section{Tax Policy}

- $\quad$ The Fund has supported many but not all of the government's tax-cutting initiatives.

- $\quad$ Staff concerns over lowering personal and corporate income taxes to a flat 12 percent in 2006 and 10 percent in 2007 proved misplaced, since revenues held up much better than projected.

- $\quad$ Fund advice to abolish the double deduction for depreciation, to harmonize minimum contribution bases for social insurance (and abolish so-called complexity factors), to introduce a simplified tax system for small businesses, and to base health contributions for part-time workers on hours actually worked rather than assuming full time work (which will reduce the labor tax wedge and help encourage part-time work) has been followed, and generally has been effective. 
Table 1. Effectiveness of Fund Policy Advice (Concluded)

\section{Rationalizing Government Spending}

- $\quad$ At the government's request, FAD technical assistance gave detailed advice to help it meet its 2006 manifesto commitment to cut the share of government spending in the economy by 2 percent of GDP (to help pay for planned tax cuts).

- $\quad$ However, with tax revenues rising sharply, the government ignored this goal and did not implement these recommendations.

\section{Banking Law}

- $\quad$ The new Banking Law, adopted by Parliament in May 2007, was prepared with the help of extensive MCM TA.

- In keeping with international best practice, the new law strengthens banks' governance, tightens provisions on connected lending, and establishes a framework for consolidated supervision.

- The law also contains provisions to protect the governor's decisions in the areas of bank licensing, administration and bankruptcy from reversal by the courts. This enabled the NBRM to successfully close a small but lingering problem bank in October 2007.

- However, contrary to the government's earlier assessment, critical provisions of the new Law have recently been found unconstitutional. Corrective amendments now need to be prepared.

\section{Central Bank Law}

- $\quad$ A new Central Bank law, prepared with the help of MCM and LEG TA, is expected to be submitted to Parliament soon.

- $\quad$ The primary objective of the NBRM will remain to achieve and maintain domestic price stability, and the NBRM will retain full autonomy in achieving that goal. However, responsibility for the exchange rate regime will be shared by the NBRM and MOF.

- $\quad$ The draft law strengthens the NBRM's governance, including by providing a clearer division of responsibilities between the Governor and the NBRM Council.

For both the 2007 Banking Law and the pending Central Bank Law, the effectiveness of Fund technical assistance was enhanced by the anchor provided by the Stand-By Arrangement. 
Table 2. FYR Macedonia: Selected Economic Indicators, 2004-08

\begin{tabular}{|c|c|c|c|c|c|}
\hline & 2004 & 2005 & 2006 & 2007 & $\begin{array}{l}2008 \\
\text { Proj. }\end{array}$ \\
\hline & \multicolumn{5}{|c|}{ (Percent change) } \\
\hline \multicolumn{6}{|l|}{ Real economy } \\
\hline Real GDP & 4.1 & 4.1 & 4.0 & 5.0 & 5.5 \\
\hline \multicolumn{6}{|l|}{ Consumer prices } \\
\hline Period average & -0.4 & 0.5 & 3.2 & 2.3 & 8.5 \\
\hline End of period & -2.1 & 1.6 & 3.0 & 6.7 & 5.5 \\
\hline Real wages, period average & 4.4 & 2.0 & 4.1 & 5.6 & $\ldots$ \\
\hline Unemployment rate (average) & 37.2 & 37.3 & 36.0 & 34.9 & 34.8 \\
\hline \multicolumn{6}{|c|}{ (In percent of GDP, unless otherwise indicated) } \\
\hline \multicolumn{6}{|l|}{ Government finances } \\
\hline Central government balance & 0.7 & 0.3 & -0.5 & 0.6 & -1.5 \\
\hline Revenues (including grants) & 36.5 & 35.6 & 32.9 & 34.3 & 36.8 \\
\hline Expenditures & 35.8 & 35.3 & 33.4 & 33.7 & 38.2 \\
\hline \multicolumn{6}{|l|}{ Central Government debt 1/ } \\
\hline Gross & 36.6 & 39.5 & 31.5 & 24.2 & 21.7 \\
\hline Net & 32.5 & 31.9 & 22.5 & 25.6 & 17.8 \\
\hline \multicolumn{6}{|l|}{ Money and credit } \\
\hline Broad money (M3, percent change) & 16.1 & 14.9 & 24.5 & 29.4 & 13.0 \\
\hline Private sector credit growth (percent change) & 25.0 & 20.5 & 30.5 & 39.1 & 35.1 \\
\hline Short-term lending rate (percent) $2 /$ & 11.8 & 10.8 & 9.5 & 8.6 & 8.7 \\
\hline \multirow[t]{2}{*}{ NBRM short-term rate (28-day bill, end-period) 3/ } & 10.0 & 8.5 & 5.8 & 4.8 & 7.0 \\
\hline & \multicolumn{5}{|c|}{ (In millions of euros, unless otherwise indicated) } \\
\hline \multicolumn{6}{|l|}{ Balance of payments } \\
\hline Exports & 1,345 & 1,643 & 1,903 & 2,441 & 2,949 \\
\hline Imports & 2,259 & 2,501 & 2,923 & 3,614 & 4,694 \\
\hline Trade balance & -914 & -858 & $-1,020$ & $-1,173$ & $-1,745$ \\
\hline In percent of GDP & -21.1 & -18.4 & -20.1 & -20.9 & -27.6 \\
\hline Current account balance & -363 & -121 & -45 & -171 & -881 \\
\hline In percent of GDP & -8.4 & -2.6 & -0.9 & -3.0 & -14.0 \\
\hline Overall balance & -23 & 345 & 305 & 65 & -65 \\
\hline Official gross reserves & 717 & 1,123 & 1,417 & 1,524 & 1,507 \\
\hline In months of imports & 2.9 & 4.0 & 4.1 & 3.4 & 3.2 \\
\hline External debt service ratio $4 /$ & 20.7 & 18.4 & 22.6 & 30.7 & 27.5 \\
\hline External debt to GDP ratio (percent) 5/ & 47.9 & 53.9 & 49.1 & 48.4 & 54.2 \\
\hline \multicolumn{6}{|l|}{ Exchange rate } \\
\hline Denars/Dollar (average) 6/ & 48.6 & 49.3 & 48.8 & 44.7 & 40.3 \\
\hline Denars/Euro (average) 6/ & 61.3 & 61.3 & 61.2 & 61.2 & 61.2 \\
\hline Real effective exchange rate (CPI-based, percent change) $7 /$ & -2.3 & -3.4 & -1.6 & -2.0 & 4.3 \\
\hline
\end{tabular}

Sources: Data provided by the authorities; and IMF staff projections.

1/ Movements in 2005 and 2006 reflect the issuance of a Euro 150 million Eurobond and repayment of the London club debt. Net debt is defined as gross debt minus NBRM deposits of the central government.

2/ Weighted averages for December of each year. For 2008, the data is for September.

$3 /$ For 2008, the data is as of October.

4/ Debt service due including IMF as percent of exports of goods and services. Excludes rollover of trade credits.

5/ Total external debt, including trade credit. Revised methodology applied to data beginning in 2004.

6/ Data for 2008 is through end-September.

7/ Data for 2008 is through end-June. 
Table 3. Macedonia: Balance of Payments (Baseline), 2007-13 1/

(In millions of Euros)

\begin{tabular}{|c|c|c|c|c|c|c|c|c|}
\hline \multirow[b]{3}{*}{ Current account } & \multirow{3}{*}{$\begin{array}{r}2007 \\
\text { Prel. } \\
-171\end{array}$} & \multicolumn{2}{|c|}{2008} & \multirow[t]{2}{*}{2009} & \multirow{2}{*}{$\frac{2010}{P}$} & \multirow{2}{*}{$\frac{2011}{\text { jections }}$} & \multirow[t]{2}{*}{2012} & \multirow[t]{2}{*}{2013} \\
\hline & & \multirow{2}{*}{$\begin{array}{r}\text { Prog. } \\
-343\end{array}$} & \multirow{2}{*}{$\begin{array}{l}\text { Proj. } \\
-881\end{array}$} & & & & & \\
\hline & & & & -916 & -919 & -990 & -986 & -939 \\
\hline (Excluding official transfers) & -195 & -410 & -945 & -992 & $-1,018$ & $-1,098$ & $-1,101$ & $-1,055$ \\
\hline Trade balance (fob) & $-1,173$ & $-1,471$ & $-1,745$ & $-1,842$ & $-1,963$ & $-2,087$ & $-2,136$ & $-2,149$ \\
\hline Exports & 2,441 & 2,690 & 2,949 & 3,107 & 3,430 & 3,795 & 4,115 & 4,432 \\
\hline Imports & $-3,614$ & $-4,161$ & $-4,694$ & $-4,949$ & $-5,394$ & $-5,882$ & $-6,251$ & $-6,581$ \\
\hline Services (net) & 26 & 33 & 27 & 28 & 41 & 59 & 72 & 85 \\
\hline Income (net; including net interest) /2 & -33 & -20 & -132 & -194 & -172 & -215 & -262 & -290 \\
\hline Of which: Telecom dividend & 0 & -71 & -71 & -92 & -30 & -30 & -30 & -30 \\
\hline Transfers (net) & 1,010 & 1,115 & 970 & 1,092 & 1,175 & 1,254 & 1,339 & 1,415 \\
\hline Official & 24 & 67 & 63 & 76 & 100 & 107 & 115 & 116 \\
\hline Private & 986 & 1,048 & 906 & 1,016 & 1,075 & 1,146 & 1,224 & 1,299 \\
\hline Of which: cash exchange & 695 & 750 & 605 & 710 & 755 & 808 & 866 & 921 \\
\hline Capital and financial account & 306 & 594 & 838 & 875 & 1,090 & 1,054 & 1,014 & 969 \\
\hline Capital account (net) & 1 & -20 & -25 & 0 & 0 & 0 & 0 & 0 \\
\hline Financial account & 304 & 614 & 863 & 875 & 1,090 & 1,054 & 1,014 & 969 \\
\hline Net disbursements & -39 & 205 & 86 & 191 & 372 & 361 & 327 & 286 \\
\hline Disbursements & 300 & 451 & 295 & 489 & 692 & 707 & 715 & 709 \\
\hline Amortization & -339 & -246 & -209 & -298 & -320 & -346 & -388 & -424 \\
\hline Of which: prepayments $3 /$ & 170 & 0 & 0 & 0 & 0 & 0 & 0 & 0 \\
\hline Direct and portfolio investment (net) & 351 & 407 & 511 & 540 & 571 & 555 & 563 & 574 \\
\hline Direct investment & 240 & 282 & 515 & 481 & 496 & 478 & 482 & 487 \\
\hline Of which: nonprivatization related FDI & 250 & 282 & 493 & 481 & 496 & 478 & 482 & 487 \\
\hline Portfolio investment & 111 & 125 & -5 & 59 & 75 & 78 & 81 & 87 \\
\hline Currency and deposits (net) & 6 & -48 & 96 & 39 & 35 & 30 & 24 & 19 \\
\hline Of which: commercial banks & 68 & 31 & 122 & 110 & 110 & 110 & 110 & 110 \\
\hline Other credits (net) & -13 & 50 & 170 & 105 & 111 & 108 & 99 & 90 \\
\hline Of which: trade credits & -33 & 38 & 175 & 90 & 95 & 90 & 80 & 70 \\
\hline Errors and omissions & -70 & 0 & -22 & 0 & 0 & 0 & 0 & 0 \\
\hline Overall balance & 65 & 251 & -65 & -41 & 171 & 64 & 27 & 30 \\
\hline Financing & -65 & -251 & 65 & 41 & -171 & -64 & -27 & -30 \\
\hline Net foreign assets (flows) & -144 & -251 & 30 & 41 & -171 & -64 & -27 & -30 \\
\hline Valuation effects on the stock of NFA (increase: -) & -6 & 0 & 4 & 0 & 0 & 0 & 0 & 0 \\
\hline Change in the stock of NFA (increase:-) & -149 & -251 & 34 & 41 & -171 & -64 & -27 & -30 \\
\hline Change in gross foreign reserves (increase:-) & -108 & -251 & 17 & 41 & -171 & -64 & -27 & -30 \\
\hline IMF (net) & -42 & 0 & 0 & 0 & 0 & 0 & 0 & 0 \\
\hline Other (net) & 0 & 0 & 17 & 0 & 0 & 0 & 0 & 0 \\
\hline Change in arrears 4/ & 79 & 0 & 35 & 0 & 0 & 0 & 0 & 0 \\
\hline
\end{tabular}

Sources: Data provided by the authorities; and IMF staff estimates and projections.

1/ NBRM recently issued revised BOP statistics based on new surveys and other sources, resulting in some changes to current and capital accounts from 2003 onwards.

2/ For 2008 and beyond, the figures include accrued interest on reserves.

3/ Amortization payments include prepayment of London Club debt in 2006 and Paris Club debt in 2007.

4/ Private sector arrears.

$5 /$ Gross international reserves in percent of short-term debt (residual basis) plus current account deficit ( 0 if surplus)

6/ Revised debt series completed end-2007 resulted in upward revisions in debt stock beginning 2004. Program figures (2008) were adjusted for 7/ Debt service due including IMF as percent of exports of goods and services. Excludes rollover of trade credits.

8/ Including IMF. 
Table 3. FYR Macedonia: Medium-Term Balance of Payments (Baseline), 2007-13, (Concluded) 1/

\begin{tabular}{|c|c|c|c|c|c|c|c|c|}
\hline & \multirow{2}{*}{$\begin{array}{c}2007 \\
\text { Prel. }\end{array}$} & \multicolumn{2}{|c|}{2008} & 2009 & 2010 & 2011 & 2012 & 2013 \\
\hline & & Prog. & Proj. & \multicolumn{5}{|c|}{ Projections } \\
\hline \multicolumn{9}{|l|}{ Memorandum items: } \\
\hline Current account (in percent of GDP) & -3.0 & -5.8 & -14.0 & -13.3 & -12.2 & -12.1 & -11.3 & -10.0 \\
\hline (Excluding official transfers) & -3.5 & -6.9 & -15.0 & -14.4 & -13.5 & -13.4 & -12.6 & -11.3 \\
\hline Trade balance (in percent of GDP) & -20.9 & -24.8 & -27.6 & -26.7 & -26.1 & -25.5 & -24.4 & -22.9 \\
\hline Exports f.o.b. (in percent of GDP) & 43.5 & 45.3 & 46.7 & 45.1 & 45.6 & 46.4 & 47.0 & 47.3 \\
\hline Imports, f.o.b. (in percent of GDP) & 64.5 & 70.1 & 74.4 & 71.8 & 71.6 & 71.9 & 71.3 & 70.2 \\
\hline Non-energy trade balance (in percent of GDP) & -11.0 & -14.5 & -15.5 & -17.5 & -16.6 & -17.0 & -16.4 & -15.7 \\
\hline Of which: vehicles (in percent of GDP) & -3.8 & -4.3 & -4.8 & $\ldots$ & $\ldots$ & $\ldots$ & $\ldots$ & $\ldots$ \\
\hline food (in percent of GDP) & -3.8 & -3.5 & -3.5 & $\ldots$ & $\ldots$ & $\ldots$ & $\ldots$ & $\ldots$ \\
\hline iron \& steel (in percent of GDP) & 7.5 & 6.9 & 4.6 & $\ldots$ & $\ldots$ & $\ldots$ & $\ldots$ & $\ldots$ \\
\hline Energy trade balance (in percent of GDP) & -9.9 & -10.3 & -12.1 & -9.3 & -9.4 & -8.5 & -7.9 & -7.3 \\
\hline Of which: electricity (in percent of GDP) & -3.2 & -3.6 & -4.8 & $\ldots$ & $\ldots$ & $\ldots$ & $\ldots$ & $\ldots$ \\
\hline Export growth (value, fob) & 28.3 & 9.6 & 20.8 & 5.3 & 10.4 & 10.6 & 8.4 & 7.7 \\
\hline Import growth (value, fob) & 23.6 & 16.4 & 29.9 & 5.4 & 9.0 & 9.1 & 6.3 & 5.3 \\
\hline Export growth rate (volumes) & 19.3 & 15.8 & 20.8 & 8.7 & 12.6 & 11.8 & 9.8 & 9.1 \\
\hline Import growth rate (volumes) & 19.0 & 15.9 & 22.1 & 10.2 & 10.5 & 8.9 & 6.5 & 5.4 \\
\hline Export price increase & 7.6 & -5.3 & 0.0 & -3.1 & -1.9 & -1.0 & -1.2 & -1.3 \\
\hline Import price increase & 3.9 & 0.4 & 6.3 & -4.4 & -1.3 & 0.1 & -0.2 & -0.1 \\
\hline Terms of trade & 105.2 & 96.8 & 98.9 & 100.2 & 99.6 & 98.4 & 97.4 & 96.2 \\
\hline Nickel prices (in thousands of Euros/metric tonne) & 27.1 & 20.4 & 15.1 & 12.1 & 11.5 & 11.0 & 10.8 & 10.5 \\
\hline Oil prices (US\$ per barrel) & 71 & 87 & 101 & 75 & 81 & 84 & 86 & 86 \\
\hline Oil prices (Euro per barrel) & 52 & 59 & 68 & 53 & 54 & 55 & 56 & 56 \\
\hline Food prices (world), percent change (Euro-based index) & 5.6 & 1.9 & 19.3 & 0.4 & -7.7 & -1.4 & -2.0 & -1.9 \\
\hline Net income (in percent of GDP) & -0.6 & -0.3 & -2.1 & -2.8 & -2.3 & -2.6 & -3.0 & -3.1 \\
\hline Private transfers, net (in percent of GDP) & 17.6 & 17.7 & 14.4 & 14.7 & 14.3 & 14.0 & 14.0 & 13.9 \\
\hline Of which: cash exchange (in percent of GDP) & 12.4 & 12.6 & 9.6 & 10.3 & 10.0 & 9.9 & 9.9 & 9.8 \\
\hline formal remittances (in percent of GDP) & 2.8 & 2.7 & 2.6 & 2.4 & 2.3 & 2.3 & 2.3 & 2.3 \\
\hline other private transfers (in percent of GDP) & 2.4 & 2.3 & 2.2 & 2.0 & 1.9 & 1.8 & 1.8 & 1.7 \\
\hline Net FDI (in percent of GDP) & 4.3 & 4.7 & 8.2 & 7.0 & 6.6 & 5.8 & 5.5 & 5.2 \\
\hline Of which: nonprivatization related FDI (in percent of GDP) & 4.5 & 4.7 & 7.8 & 7.0 & 6.6 & 5.8 & 5.5 & 5.2 \\
\hline Gross reserves (in millions of Euros) & 1,524 & 1,774 & 1,507 & 1,467 & 1,638 & 1,702 & 1,729 & 1,759 \\
\hline (In months of following year's imports of G\&S) & 3.4 & 4.1 & 3.2 & 2.8 & 2.9 & 2.8 & 2.7 & 2.7 \\
\hline Reserve Cover 5/ & 117.3 & 107.4 & 67.5 & 53.0 & 51.8 & 47.0 & 43.3 & 40.7 \\
\hline Short-term debt (in percent of official reserves) 6/ & 66.6 & 75.1 & 94.4 & 119.9 & 128.5 & 143.5 & 160.3 & 175.9 \\
\hline On residual basis (in percent of official reserves) & 88.8 & 89.0 & 108.3 & 140.3 & 148.0 & 163.8 & 182.7 & 199.9 \\
\hline Excl. intercompany- (FDI) related loans & 65.6 & $\ldots$ & 77.3 & 100.1 & 104.5 & 114.9 & 127.6 & 138.9 \\
\hline External debt service ratio (in percent) $6 / 7 /$ & 30.7 & 11.9 & 27.5 & 33.1 & 37.0 & 39.9 & 42.9 & 45.1 \\
\hline External debt to GDP ratio (in percent) 6/ $8 /$ & 48.4 & 55.2 & 54.2 & 59.0 & 65.2 & 70.0 & 74.2 & 77.2 \\
\hline Medium- and long-term (in percent of GDP) & 30.3 & 32.8 & 31.6 & 33.5 & 37.2 & 40.1 & 42.6 & 44.2 \\
\hline Short-term (in percent of GDP) & 18.1 & 22.4 & 22.5 & 25.5 & 27.9 & 29.8 & 31.6 & 33.0 \\
\hline Of which: Intercompany lending (direct investment) & 6.3 & $\ldots$ & 7.4 & 8.5 & 9.5 & 10.2 & 10.9 & 11.5 \\
\hline Nominal GDP (in millions of euros) & 5,607 & 5,938 & 6,313 & 6,895 & 7,530 & 8,182 & 8,765 & 9,373 \\
\hline
\end{tabular}

Sources: Data provided by the authorities; and IMF staff estimates and projections.

1/ NBRM recently issued revised BOP statistics based on new surveys and other sources, resulting in some changes to current and capital accounts from 2003 onwards.

2/ For 2008 and beyond, the figures include accrued interest on reserves.

3/ Amortization payments include prepayment of London Club debt in 2006 and Paris Club debt in 2007.

4/ Private sector arrears.

$5 /$ Gross international reserves in percent of short-term debt (residual basis) plus current account deficit ( 0 if surplus)

6/ Revised debt series completed end-2007 resulted in upward revisions in debt stock beginning 2004. Program figures (2008) were adjusted for

7/ Debt service due including IMF as percent of exports of goods and services. Excludes rollover of trade credits.

8/ Including IMF. 
Table 4. FYR Macedonia: Indicators of Financial and External Vulnerability, 2004-08

\begin{tabular}{|c|c|c|c|c|c|}
\hline & 2004 & 2005 & 2006 & 2007 & 2008 \\
\hline \multicolumn{6}{|l|}{ Financial indicators } \\
\hline Broad money (end of period; percent change from end of previous year) & 16.1 & 14.9 & 24.5 & 29.4 & 13.0 \\
\hline Private sector credit (end of period; percent change from end of previous year) & 25.0 & 20.5 & 30.5 & 39.1 & 35.1 \\
\hline Share of non-performing loans in total bank exposure (end of period, in percent) & 13.2 & 10.9 & 7.6 & 5.7 & $\ldots$ \\
\hline NPLs of nonfinancial private sector/gross loans to nonfinancial private sector (percent) $1 /$ & 17.0 & 15.0 & 11.2 & 7.5 & 6.9 \\
\hline Foreign currency deposits (end of period, in percent of broad money) & 44.8 & 46.9 & 44.6 & 39.0 & 41.9 \\
\hline \multicolumn{6}{|l|}{ Indexed and foreign currency credit to private sector } \\
\hline (end of period, in percent of total credit to private sector) & 42.3 & 47.8 & 54.4 & 57.1 & 55.8 \\
\hline \multicolumn{6}{|l|}{ External Indicators } \\
\hline Exports (percent change, in terms of Euro) & 11.8 & 22.2 & 15.8 & 28.3 & 20.8 \\
\hline Imports (percent change, in terms of Euro) & 15.5 & 10.7 & 16.9 & 23.6 & 29.9 \\
\hline \multicolumn{6}{|l|}{ Current account balance (in percent of GDP) } \\
\hline (Including official grants) & -8.4 & -2.6 & -0.9 & -3.0 & -14.0 \\
\hline (Excluding official grants) & -9.7 & -3.7 & -2.0 & -3.5 & -15.0 \\
\hline Foreign direct investment (in percent of GDP) & 6.0 & 1.6 & 6.8 & 4.3 & 8.2 \\
\hline \multicolumn{6}{|l|}{ Gross official reserves } \\
\hline (In millions of euros) & 717 & 1,123 & 1,417 & 1,524 & 1,507 \\
\hline (In months of next year's imports of goods and services) & 2.9 & 4.0 & 4.1 & 3.4 & 3.2 \\
\hline (In percent of private denar broad money) & 84.1 & 119.0 & 115.5 & 86.8 & 74.0 \\
\hline (In percent of broad money) & 46.4 & 63.7 & 64.1 & 53.0 & 44.0 \\
\hline Ratio of indexed and foreign currency deposit to gross official reserves & 114.4 & 78.6 & 75.1 & 73.4 & 90.8 \\
\hline Ratio of NFA of the monetary system to broad money (in percent) & 72.7 & 80.3 & 78.0 & 61.0 & 48.7 \\
\hline Total external debt (in percent of GDP) & 47.9 & 53.9 & 49.1 & 48.4 & 54.2 \\
\hline Of which: public sector (in percent of GDP) & 27.8 & 31.6 & 24.8 & 18.9 & 17.8 \\
\hline \multicolumn{6}{|l|}{ Short-term external debt (by remaining maturity, including trade credit) } \\
\hline (In percent of GDP) & 13.4 & 14.8 & 14.1 & 18.1 & 22.5 \\
\hline (In percent of official reserves) & 80.8 & 61.6 & 50.5 & 66.6 & 94.4 \\
\hline External debt service payments (in percent of exports of goods and services) $2 /$ & 20.7 & 18.4 & 22.6 & 30.7 & 27.5 \\
\hline Exchange rate (denar per U.S. dollar, period average) & 48.6 & 49.3 & 48.8 & 44.7 & 40.3 \\
\hline \multicolumn{6}{|l|}{ REER (average percent change; (-) depreciation) } \\
\hline CPI-based & -2.3 & -3.4 & -1.6 & -2.0 & 4.3 \\
\hline ULC-based & 5.7 & -13.8 & -5.3 & -9.1 & 6.7 \\
\hline
\end{tabular}

Source: Staff calculations and estimates based on the data provided by the NBRM.

1/ Data as of 2008 Q2.

2/ Excluding trade credit. 
Table 5. FYR Macedonia: Central Government Operations, 2006-09

\begin{tabular}{|c|c|c|c|c|c|c|c|}
\hline & \multirow[t]{2}{*}{2006} & \multirow[t]{2}{*}{2007} & \multicolumn{3}{|c|}{2008} & \multicolumn{2}{|c|}{2009} \\
\hline & & & Program & Baseline & $\overline{\text { Alternative }}$ & Baseline & $\overline{\text { Alternative }}$ \\
\hline & \multicolumn{7}{|c|}{ (In percent of GDP) } \\
\hline Total revenue & 32.9 & 34.3 & 32.7 & 36.8 & 36.8 & 34.5 & 34.5 \\
\hline Tax revenue & 28.7 & 29.5 & 27.1 & 30.1 & 30.1 & 29.0 & 29.0 \\
\hline Personal Income Tax & 2.7 & 2.6 & 2.2 & 2.3 & 2.3 & 2.3 & 2.3 \\
\hline Corporate Income Tax & 1.5 & 1.7 & 1.4 & 2.3 & 2.3 & 2.3 & 2.3 \\
\hline VAT & 8.8 & 9.6 & 9.4 & 10.0 & 10.0 & 10.0 & 10.0 \\
\hline Excises & 3.9 & 3.9 & 3.7 & 3.7 & 3.7 & 3.7 & 3.7 \\
\hline Custom Duties & 1.7 & 1.8 & 1.9 & 1.9 & 1.9 & 1.9 & 1.9 \\
\hline Other taxes & 0.6 & 0.7 & 0.7 & 0.7 & 0.7 & 0.7 & 0.7 \\
\hline Pension contributions & 6.0 & 5.8 & 5.2 & 5.9 & 5.9 & 5.2 & 5.2 \\
\hline Unemployment contributions & 0.4 & 0.4 & 0.4 & 0.4 & 0.4 & 0.4 & 0.4 \\
\hline Health contributions & 3.0 & 2.9 & 2.4 & 2.9 & 2.9 & 2.4 & 2.4 \\
\hline Nontax revenue & 3.2 & 3.0 & 4.0 & 4.4 & 4.4 & 3.9 & 3.9 \\
\hline Capital Revenue & 0.6 & 1.4 & 1.1 & 1.7 & 1.7 & 1.1 & 1.1 \\
\hline Of which: Telecom dividend & 0.0 & 0.8 & 0.7 & 1.0 & 1.0 & 0.7 & 0.7 \\
\hline Grants & 0.5 & 0.3 & 0.5 & 0.6 & 0.6 & 0.5 & 0.5 \\
\hline Total expenditure & 33.4 & 33.7 & 34.1 & 38.2 & 35.3 & 37.5 & 34.5 \\
\hline Current expenditure & 30.5 & 29.7 & 28.6 & 31.3 & 31.3 & 30.6 & 30.6 \\
\hline Wages and salaries & 7.5 & 6.9 & 6.0 & 5.9 & 5.9 & 5.9 & 5.9 \\
\hline Goods and services & 4.2 & 4.3 & 4.8 & 5.6 & 5.6 & 4.8 & 4.8 \\
\hline Transfers & 17.8 & 17.6 & 17.1 & 19.1 & 19.1 & 19.1 & 19.1 \\
\hline Pensions & 8.2 & 7.7 & 7.4 & 8.1 & 8.1 & 8.1 & 8.1 \\
\hline Health & 5.1 & 4.7 & 4.2 & 4.7 & 4.7 & 4.7 & 4.7 \\
\hline Local governments & 0.7 & 1.1 & 2.5 & 2.7 & 2.7 & 2.7 & 2.7 \\
\hline MEPSO subsidies & $\ldots$ & 0.2 & 0.2 & 0.4 & 0.4 & 0.4 & 0.4 \\
\hline Other & $\ldots$ & $\ldots$ & $\ldots$ & 3.2 & 3.2 & 3.2 & 3.2 \\
\hline Interest & 1.0 & 0.8 & 0.6 & 0.7 & 0.7 & 0.7 & 0.7 \\
\hline Capital expenditure & 3.0 & 4.0 & 5.5 & 6.9 & 4.0 & 6.9 & 3.9 \\
\hline Lending minus repayment & 0.0 & 0.0 & 0.0 & 0.0 & 0.0 & 0.0 & 0.0 \\
\hline Fiscal Balance & -0.5 & 0.6 & -1.4 & -1.5 & 1.5 & -3.0 & 0.0 \\
\hline Fiscal Balance below the line & -0.4 & 1.1 & -1.4 & -1.5 & 1.5 & -3.0 & 0.0 \\
\hline Financing & 0.4 & -1.1 & 1.4 & 1.5 & -1.5 & 3.0 & 0.0 \\
\hline Domestic & -3.2 & 2.2 & 0.6 & -0.3 & -3.3 & 0.7 & -1.2 \\
\hline Central Bank & -2.3 & 3.7 & 0.9 & 0.3 & -2.7 & 1.0 & -0.9 \\
\hline Other domestic financing & -0.9 & -1.5 & -0.3 & -0.6 & -0.6 & -0.3 & -0.3 \\
\hline Privatization receipts & 6.5 & -0.2 & 0.1 & 0.9 & 0.9 & 0.2 & 0.2 \\
\hline Foreign & -3.0 & -3.1 & 0.8 & 0.9 & 0.9 & 2.1 & 1.0 \\
\hline \multicolumn{8}{|l|}{ Memorandum items: } \\
\hline Contributions to second pillar pensions & 0.4 & 0.5 & 0.6 & 0.6 & 0.6 & 0.6 & 0.6 \\
\hline GDP (billion denars) & 310.9 & 343.0 & 387.1 & 387.1 & 384.3 & 422.7 & 411.7 \\
\hline
\end{tabular}

Source: MOF and IMF staff estimates. 
Table 5. FYR Macedonia: Central Government Operations, 2006-09 (Concl.)

\begin{tabular}{|c|c|c|c|c|c|c|c|}
\hline & \multirow[t]{2}{*}{2006} & \multirow[t]{2}{*}{2007} & \multicolumn{3}{|c|}{2008} & \multirow{2}{*}{\multicolumn{2}{|c|}{$\frac{2009}{\text { baseline alternative }}$}} \\
\hline & & & prog. & baseline & alternative & & \\
\hline & \multicolumn{7}{|c|}{ (In billion denars) } \\
\hline Total revenue & 102.3 & 117.6 & 126.4 & 142.3 & 141.3 & 145.8 & 142.0 \\
\hline Tax revenue & 89.2 & 101.3 & 105.0 & 116.5 & 115.6 & 122.6 & 119.4 \\
\hline Personal Income Tax & 8.4 & 8.9 & 8.3 & 8.9 & 8.8 & 9.7 & 9.5 \\
\hline Corporate Income Tax & 4.7 & 5.9 & 5.3 & 9.0 & 8.9 & 9.8 & 9.6 \\
\hline VAT & 27.2 & 33.0 & 36.3 & 38.6 & 38.4 & 42.2 & 41.1 \\
\hline Excises & 12.2 & 13.3 & 14.2 & 14.4 & 14.3 & 15.7 & 15.3 \\
\hline Custom Duties & 5.4 & 6.2 & 7.4 & 7.4 & 7.4 & 8.1 & 7.9 \\
\hline Other taxes & 1.8 & 2.5 & 2.6 & 2.7 & 2.7 & 3.0 & 2.9 \\
\hline Pension contributions & 18.6 & 20.1 & 20.2 & 22.6 & 22.5 & 22.2 & 21.6 \\
\hline Unemployment contributions & 1.4 & 1.5 & 1.5 & 1.7 & 1.6 & 1.6 & 1.5 \\
\hline Health contributions & 9.4 & 10.0 & 9.2 & 11.2 & 11.1 & 10.4 & 10.1 \\
\hline Non Tax revenue & 9.9 & 10.4 & 15.3 & 17.0 & 16.9 & 16.5 & 16.1 \\
\hline Capital Revenue & 1.8 & 4.9 & 4.1 & 6.6 & 6.5 & 4.7 & 4.5 \\
\hline Of which: Telecom dividend & 0.0 & 2.9 & 2.6 & 3.7 & 3.7 & 3.0 & 2.9 \\
\hline Grants & 1.4 & 0.9 & 2.0 & 2.2 & 2.2 & 2.1 & 2.1 \\
\hline Total expenditure & 104.0 & 115.4 & 132.0 & 147.9 & 135.7 & 158.5 & 142.0 \\
\hline Current expenditure & 94.8 & 101.8 & 110.5 & 121.1 & 120.3 & 129.2 & 125.8 \\
\hline Wages and salaries & 23.4 & 23.6 & 23.2 & 23.0 & 22.7 & 25.1 & 24.4 \\
\hline Goods and services & 12.9 & 14.8 & 18.7 & 21.5 & 21.5 & 20.4 & 19.8 \\
\hline Transfers & 55.3 & 60.5 & 66.3 & 73.9 & 73.4 & 80.7 & 78.6 \\
\hline Pensions & 25.4 & 26.3 & 28.5 & 31.3 & 31.1 & 34.2 & 33.3 \\
\hline Health & 15.8 & 16.1 & 16.3 & 18.1 & 18.1 & 19.8 & 19.3 \\
\hline Local governments & 2.1 & 3.7 & 9.5 & 10.5 & 10.4 & 11.4 & 11.1 \\
\hline MEPSO subsidies & $\ldots$ & 0.8 & 0.8 & 1.5 & 1.5 & 1.6 & 1.6 \\
\hline Other & $\ldots$ & $\ldots$ & $\ldots$ & 12.5 & 12.3 & 13.7 & 13.2 \\
\hline Interest & 3.1 & 2.9 & 2.3 & 2.7 & 2.7 & 3.0 & 2.9 \\
\hline Capital expenditure & 9.3 & 13.7 & 21.4 & 26.9 & 15.4 & 29.4 & 16.3 \\
\hline Lending minus repayment & 0.0 & -0.1 & 0.0 & -0.1 & -0.1 & -0.1 & -0.1 \\
\hline Fiscal Balance & -1.7 & 2.2 & -5.5 & -5.7 & 5.8 & -12.7 & 0.0 \\
\hline Fiscal Balance below the line & -1.1 & 3.7 & -5.542 & -5.7 & 5.8 & -12.7 & 0.0 \\
\hline Financing & 1.1 & -3.7 & 5.542 & 5.7 & -5.8 & 12.7 & 0.0 \\
\hline Domestic & -9.8 & 7.5 & 2.146 & -1.2 & -12.6 & 3.0 & -4.9 \\
\hline Central Bank & -7.2 & 12.7 & 3.3 & 1.2 & -10.2 & 4.2 & -3.7 \\
\hline Other domestic financing & -2.6 & -5.2 & -1.154 & -2.4 & -2.4 & -1.3 & -1.2 \\
\hline Privatization receipts & 20.3 & -0.7 & 0.2 & 3.3 & 3.4 & 0.8 & 0.8 \\
\hline Foreign & -9.4 & -10.5 & 3.196 & 3.5 & 3.5 & 8.9 & 4.1 \\
\hline \multicolumn{8}{|l|}{ Memorandum items: } \\
\hline Contributions to second pillar pensions & 1.3 & 1.9 & 2.31 & 2.3 & 2.3 & 2.5 & 2.5 \\
\hline GDP & 310.9 & 343.0 & 387.1 & 387.1 & 384.3 & 422.7 & 411.7 \\
\hline
\end{tabular}

Source: MOF and IMF Staff estimates. 
Table 6. FYR Macedonia: Macroeconomic Framework (Baseline), 2007-13

(Percentage change, unless otherwise indicated)

\begin{tabular}{|c|c|c|c|c|c|c|c|c|}
\hline \multirow[b]{3}{*}{ Real GDP } & \multirow{3}{*}{$\begin{array}{r}2007 \\
\text { Est. } \\
5.0\end{array}$} & \multicolumn{2}{|c|}{2008} & \multirow{2}{*}{2009} & \multirow{2}{*}{$\frac{2010}{F}$} & \multirow{2}{*}{$\frac{2011}{\text { jections }}$} & \multirow[t]{2}{*}{2012} & \multirow[t]{2}{*}{2013} \\
\hline & & Prog. & Proj. & & & & & \\
\hline & & 5.0 & 5.5 & 4.0 & 5.0 & 5.0 & 4.0 & 4.0 \\
\hline Real domestic demand & 6.9 & 6.6 & 8.6 & 5.8 & 5.0 & 4.3 & 2.7 & 2.1 \\
\hline Consumption & 5.6 & 5.1 & 7.1 & 6.0 & 5.2 & 4.4 & 2.8 & 2.0 \\
\hline Private & 5.6 & 5.8 & 6.5 & 6.0 & 5.0 & 4.0 & 3.0 & 2.0 \\
\hline Public & 5.5 & 2.0 & 10.0 & 6.0 & 6.0 & 6.0 & 2.0 & 2.0 \\
\hline Fixed investment & 14.4 & 14.3 & 17.9 & 5.2 & 4.3 & 3.8 & 2.1 & 2.1 \\
\hline Private & 16.2 & 14.5 & 16.5 & 5.0 & 4.0 & 3.5 & 2.5 & 2.5 \\
\hline Public & 5.8 & 13.0 & 25.0 & 6.0 & 6.0 & 5.0 & 0.0 & 0.0 \\
\hline Exports (volume) & 19.3 & 15.8 & 20.8 & 8.7 & 12.6 & 11.8 & 9.8 & 9.1 \\
\hline Imports (volume) & 19.0 & 15.9 & 22.1 & 10.2 & 10.5 & 8.9 & 6.5 & 5.4 \\
\hline Contributions to growth & 5.0 & 5.0 & 5.5 & 4.0 & 5.0 & 5.0 & 4.0 & 4.0 \\
\hline Domestic demand & 8.2 & 7.9 & 10.5 & 7.3 & 6.4 & 5.4 & 3.4 & 2.6 \\
\hline Net exports & -3.2 & -2.9 & -5.0 & -3.2 & -1.4 & -0.4 & 0.6 & 1.4 \\
\hline \multicolumn{9}{|l|}{ Central government operations (percent of GDP) } \\
\hline Revenues & 34.3 & 32.7 & 36.8 & 34.5 & 33.8 & 33.3 & 33.0 & 33.0 \\
\hline Expenditures & 33.7 & 34.1 & 38.2 & 37.5 & 37.3 & 37.3 & 35.0 & 34.0 \\
\hline Of which: capital & 4.0 & 5.5 & 6.9 & 6.9 & 6.9 & 6.5 & 4.5 & 4.0 \\
\hline Balance & 0.6 & -1.4 & -1.5 & -3.0 & -3.5 & -4.0 & -2.0 & -1.0 \\
\hline \multicolumn{9}{|l|}{ Savings and investment (percent of GDP) } \\
\hline Domestic saving & 20.1 & 18.8 & 13.2 & 13.6 & 14.2 & 13.9 & 14.3 & 15.2 \\
\hline Of which: public & 3.7 & 2.0 & 2.4 & 0.9 & 0.4 & -0.2 & 1.7 & 2.6 \\
\hline Foreign saving $1 /$ & 3.0 & 5.8 & 14.0 & 13.3 & 12.2 & 12.1 & 11.3 & 10.0 \\
\hline Gross investment & 23.2 & 24.6 & 27.1 & 26.8 & 26.4 & 26.0 & 25.6 & 25.2 \\
\hline Fixed investment & 19.7 & 21.3 & 23.4 & 23.2 & 22.8 & 22.5 & 22.0 & 21.7 \\
\hline \multicolumn{9}{|l|}{ Consumer prices } \\
\hline Period average & 2.3 & 4 to 5 & 8.5 & 3.0 & 3.0 & 3.0 & 3.0 & 3.0 \\
\hline End-period & 6.7 & 2.0 & 5.5 & 3.0 & 3.0 & 3.0 & 3.0 & 3.0 \\
\hline \multicolumn{9}{|l|}{ Memorandum items: } \\
\hline Current account balance (in percent of GDP) & -3.0 & -5.8 & -14.0 & -13.3 & -12.2 & -12.1 & -11.3 & -10.0 \\
\hline Gross official reserves (in million Euro) & 1,524 & 1,774 & 1,507 & 1,467 & 1,638 & 1,702 & 1,729 & 1,759 \\
\hline Gross official reserves (in months of imports) & 3.4 & 4.1 & 3.2 & 2.8 & 2.9 & 2.8 & 2.7 & 2.7 \\
\hline Central government gross debt (in percent of GDP) & 24.2 & 25.7 & 21.7 & 22.9 & 24.4 & 26.5 & 26.7 & 26.0 \\
\hline Foreign direct investment (percent of GDP) & 4.3 & 4.7 & 8.2 & 7.0 & 6.6 & 5.8 & 5.5 & 5.2 \\
\hline External debt (in percent of GDP) & 48.4 & 55.2 & 54.2 & 59.0 & 65.2 & 70.0 & 74.2 & 77.2 \\
\hline Nominal GDP (in billion denars) & 343.0 & 364.1 & 387.1 & 422.7 & 461.7 & 501.6 & 537.4 & 574.7 \\
\hline Nominal GDP (in million Euro) & 5,607 & 5,938 & 6,313 & 6,895 & 7,530 & 8,182 & 8,765 & 9,373 \\
\hline
\end{tabular}

Sources: NBRM; SSO; MOF; and IMF staff projections.

1/ Current account deficit. 
Table 7. FYR Macedonia: Macroeconomic Framework (Staff Alternative), 2007-13

(Percentage change, unless otherwise indicated)

\begin{tabular}{|c|c|c|c|c|c|c|c|c|}
\hline \multirow[b]{3}{*}{ Real GDP } & \multirow{3}{*}{$\begin{array}{r}2007 \\
\text { Est. } \\
5.0\end{array}$} & \multicolumn{2}{|c|}{2008} & \multirow{3}{*}{$\begin{array}{r}2009 \\
3.0\end{array}$} & \multirow{2}{*}{$\frac{2010}{P}$} & \multirow{2}{*}{$\frac{2011}{\text { jections }}$} & \multirow[t]{2}{*}{2012} & \multirow[t]{2}{*}{2013} \\
\hline & & \multirow{2}{*}{$\begin{array}{r}\text { Prog. } \\
5.0\end{array}$} & \multirow{2}{*}{$\begin{array}{r}\text { Proj. } \\
5.0\end{array}$} & & & & & \\
\hline & & & & & 5.0 & 6.0 & 6.0 & 6.0 \\
\hline Consumption & 5.6 & 5.1 & 5.3 & 4.2 & 3.8 & 3.8 & 3.6 & 3.4 \\
\hline Private & 5.6 & 5.8 & 6.0 & 5.1 & 4.6 & 4.6 & 4.3 & 4.0 \\
\hline Public & 5.5 & 2.0 & 2.0 & 0.0 & 0.0 & 0.0 & 0.0 & 0.0 \\
\hline Private & 16.2 & 14.5 & 16.5 & 5.0 & 8.0 & 9.0 & 7.0 & 7.0 \\
\hline Public & 5.8 & 13.0 & 6.0 & 7.0 & 7.0 & 8.0 & 6.0 & 6.0 \\
\hline Exports (volume) & 19.3 & 15.8 & 20.8 & 8.7 & 12.6 & 12.0 & 10.4 & 9.9 \\
\hline Imports (volume) & 19.0 & 15.9 & 19.4 & 9.4 & 9.7 & 8.6 & 6.9 & 6.5 \\
\hline Contributions to growth & 5.0 & 5.0 & 5.0 & 3.0 & 5.0 & 6.0 & 6.0 & 6.0 \\
\hline \multicolumn{9}{|l|}{ Central government operations (percent of GDP) } \\
\hline Expenditures & 33.7 & 34.1 & 35.3 & 34.5 & 34.0 & 34.5 & 34.5 & 34.5 \\
\hline Of which: capital & 4.0 & 5.5 & 4.0 & 3.9 & 6.0 & 6.5 & 6.5 & 6.5 \\
\hline Balance & 0.6 & -1.4 & 1.5 & 0.0 & 0.0 & -1.0 & -1.0 & -1.0 \\
\hline \multicolumn{9}{|l|}{ Savings and investment (percent of GDP) } \\
\hline Domestic saving & 20.1 & 18.8 & 14.5 & 15.9 & 18.0 & 18.5 & 19.5 & 20.5 \\
\hline Of which: public & 3.7 & 2.0 & 4.8 & 3.4 & 3.4 & 2.5 & 2.5 & 2.5 \\
\hline Foreign saving $1 /$ & 3.0 & 5.8 & 12.2 & 11.1 & 9.5 & 9.5 & 8.6 & 7.6 \\
\hline Gross investment & 23.2 & 24.6 & 26.7 & 27.0 & 27.5 & 28.0 & 28.1 & 28.2 \\
\hline Fixed investment & 19.7 & 21.3 & 23.0 & 23.3 & 23.8 & 24.4 & 24.5 & 24.7 \\
\hline \multicolumn{9}{|l|}{ Consumer prices } \\
\hline Foreign direct investment (percent of GDP) & 4.3 & 4.7 & 8.2 & 7.0 & 6.9 & 6.4 & 6.2 & 6.0 \\
\hline External debt (in percent of GDP) & 48.4 & 55.2 & 54.5 & 59.1 & 63.9 & 66.5 & 67.6 & 67.6 \\
\hline Nominal GDP (in billions of denars) & 343.0 & 364.1 & 384.5 & 411.8 & 447.5 & 489.5 & 535.1 & 584.5 \\
\hline Nominal GDP (in millions of euros) & 5,607 & 5,938 & 6,271 & 6,717 & 7,299 & 7,985 & 8,728 & 9,533 \\
\hline
\end{tabular}

Sources: NBRM; SSO; MOF; and IMF staff projections.

1/ Current account deficit. 
Table 8. FYR Macedonia: Central Bank Accounts 2005-09

(End-period; in billions of denars unless otherwise indicated)

\begin{tabular}{|c|c|c|c|c|c|c|}
\hline & 2005 & & 2007 & \multicolumn{2}{|c|}{2008} & 2009 \\
\hline & Dec & Dec & Dec & Sept & $\overline{\mathrm{Dec}}$ & Dec \\
\hline & Actual & Actual & Actual & Actual & Proj. & Proj \\
\hline & \multicolumn{6}{|c|}{ (At current exchange rates) } \\
\hline Net foreign assets (NFA) 1/ & 66.3 & 85.1 & 94.3 & 103.0 & 91.2 & 88.7 \\
\hline Net domestic assets (NDA) & -40.5 & -53.9 & -56.8 & -62.7 & -50.3 & -45.2 \\
\hline Banks (net) & -8.9 & -14.0 & -25.5 & -20.0 & -17.2 & -16.2 \\
\hline Of which: instruments (NBRM bills) & -8.9 & -14.0 & -25.6 & -20.0 & -17.2 & -16.2 \\
\hline Central government (net) & -18.3 & -25.5 & -12.8 & -21.1 & -11.6 & -7.4 \\
\hline Of which: deposits & -21.6 & -27.7 & -13.8 & -22.1 & -12.6 & -8.4 \\
\hline Municipalities (net) & -0.7 & -0.6 & -1.6 & -2.9 & -2.9 & -2.9 \\
\hline Other items (net) & -12.7 & -13.7 & -16.8 & -18.7 & -18.7 & -18.7 \\
\hline Reserve money & 25.8 & 31.3 & 37.6 & 38.8 & 40.9 & 43.5 \\
\hline Currency & 14.4 & 16.2 & 17.9 & 16.6 & 19.0 & 19.5 \\
\hline Other & 11.3 & 15.1 & 19.7 & 22.3 & 21.9 & 24.0 \\
\hline Cash in vaults & 1.4 & 1.5 & 2.0 & 2.3 & 2.3 & 2.3 \\
\hline Total reserves & 9.9 & 13.5 & 17.7 & 20.0 & 19.6 & 21.7 \\
\hline On denar deposits & 4.6 & 7.2 & 10.4 & 10.2 & 10.0 & 10.7 \\
\hline \multirow[t]{2}{*}{ On FX deposits } & 5.3 & 6.4 & 7.3 & 9.8 & 9.6 & 10.9 \\
\hline & \multicolumn{6}{|c|}{ (Year-on-year growth rates, percent) } \\
\hline Net foreign assets & 58.5 & 28.4 & 10.8 & 9.3 & -3.3 & -2.8 \\
\hline Reserve money & 22.0 & 21.4 & 20.2 & 19.4 & 8.7 & 6.5 \\
\hline \multirow[t]{2}{*}{ Currency } & 2.0 & 12.2 & 10.6 & -1.2 & 5.8 & 3.0 \\
\hline & \multicolumn{6}{|c|}{ (Contribution to year-on-year change in base money) } \\
\hline Net foreign assets & 115.9 & 73.1 & 29.5 & 26.9 & -8.4 & -8.0 \\
\hline Net domestic assets & -93.8 & -51.8 & -9.3 & -3.0 & 17.1 & 14.5 \\
\hline \multicolumn{7}{|l|}{ Memorandum items: } \\
\hline Reserve money/GDP (in percent) & 9.0 & 10.1 & 11.0 & 10.3 & 10.6 & 10.3 \\
\hline Program exchange rate (denars per euro) & 61.3 & 61.3 & 61.3 & 61.3 & 61.3 & 61.3 \\
\hline GDP (yearly total) 2/ & 286.6 & 310.9 & 343.0 & 376.3 & 387.1 & 422.7 \\
\hline
\end{tabular}

Sources: NBRM, and IMF staff projections.

1/ Beginning in March 2008, the projections include accrued interest on securities of 4 million euros.

2/ Measured on a rolling basis as a sum of nominal GDP of four preceding quarters including the last quarter of each period. 
Table 9. FYR Macedonia: Monetary Survey, 2005-09

(End-period; in billions of denars unless otherwise indicated)

\begin{tabular}{|c|c|c|c|c|c|c|}
\hline & 2005 & & 2007 & \multicolumn{2}{|c|}{2008} & \multirow{2}{*}{$\begin{array}{r}2009 \\
\text { Dec } \\
\text { Proj. }\end{array}$} \\
\hline & Dec & Dec & $\mathrm{Dec}$ & Sept & Dec & \\
\hline & \multicolumn{6}{|c|}{ (At current exchange rates) } \\
\hline Net foreign assets (NFA) & 89.7 & 108.0 & 109.8 & 111.9 & 100.9 & 94.6 \\
\hline NBRM 1/ & 66.3 & 85.1 & 94.3 & 103.0 & 91.2 & 88.7 \\
\hline Domestic money banks (DMBs) & 23.5 & 22.9 & 15.4 & 9.0 & 9.7 & 5.9 \\
\hline Net domestic assets (NDA) & 19.2 & 27.6 & 65.8 & 85.1 & 97.4 & 123.2 \\
\hline Credit to the government & -12.2 & -17.9 & -6.4 & -16.6 & -6.9 & -4.4 \\
\hline Banks & 6.8 & 8.2 & 8.0 & 7.4 & 7.5 & 5.9 \\
\hline NBRM (net) & -19.0 & -26.1 & -14.4 & -24.0 & -14.5 & -10.2 \\
\hline Of which: municipalities & -0.7 & -0.6 & -1.6 & -2.9 & -2.9 & 0.0 \\
\hline Credit to the private sector & 68.8 & 89.8 & 124.9 & 160.2 & 168.7 & 201.5 \\
\hline In denars $2 /$ & 51.7 & 66.4 & 94.5 & 122.4 & 131.3 & 154.5 \\
\hline In foreign currency & 17.1 & 23.4 & 30.4 & 37.8 & 37.4 & 47.1 \\
\hline Other items (net) & -37.4 & -44.3 & -52.7 & -58.5 & -64.3 & -74.0 \\
\hline Broad money (M3) & 108.9 & 135.6 & 175.5 & 197.1 & 198.3 & 217.7 \\
\hline Currency in circulation & 14.4 & 16.2 & 17.9 & 16.6 & 19.0 & 19.5 \\
\hline Private denar deposits $2 / 3 /$ & 43.4 & 59.0 & 89.1 & 98.0 & 96.2 & 103.1 \\
\hline \multirow[t]{2}{*}{ Private foreign currency deposits } & 51.1 & 60.4 & 68.5 & 82.5 & 83.1 & 95.1 \\
\hline & \multicolumn{6}{|c|}{ (Year-on-year growth rates, percent) } \\
\hline NFA domestic money banks & -13.3 & -2.3 & -32.6 & -48.4 & -37.3 & -39.3 \\
\hline Credit to the private sector & 20.5 & 30.5 & 39.1 & 38.4 & 35.1 & 19.5 \\
\hline Denar credit & 12.9 & 28.5 & 42.3 & 40.8 & 39.0 & 17.6 \\
\hline Foreign currency credit & 50.7 & 36.6 & 30.0 & 31.1 & 23.0 & 26.0 \\
\hline Broad Money & 14.9 & 24.5 & 29.4 & 22.1 & 13.0 & 9.8 \\
\hline Private denar deposits & 13.8 & 36.0 & 51.0 & 24.6 & 8.1 & 7.1 \\
\hline Private foreign currency deposits & 20.2 & 18.3 & 13.4 & 25.0 & 21.2 & 14.4 \\
\hline \multicolumn{7}{|l|}{ Memorandum items: } \\
\hline M3/GDP (percent) & 38.0 & 43.6 & 51.2 & 52.4 & 51.2 & 51.5 \\
\hline Forex and forex indexed deposits/total deposits (percent) & 68.9 & 64.6 & 61.4 & 65.9 & 67.0 & 69.0 \\
\hline Broad money multiplier (M3/reserve money) & 4.2 & 4.3 & 4.7 & 5.1 & 4.9 & 5.0 \\
\hline NFA of DMBs/forex deposits (percent) & 56.3 & 48.5 & 33.2 & 22.7 & 23.2 & 17.7 \\
\hline Private credit (percent of GDP) & 24.0 & 28.9 & 36.4 & 42.6 & 43.6 & 47.7 \\
\hline Nominal GDP (yearly total) 4/ & 286.6 & 310.9 & 343.0 & 376.3 & 387.1 & 422.7 \\
\hline
\end{tabular}

Sources: NBRM, and IMF staff projections.

1/ Beginning in March 2008, the projections include accrued interest on securities of 4 million euros.

2/ Includes foreign currency indexed.

3 / Includes municipal and public enterprise accounts.

4/ Measured on a rolling basis as a sum of nominal GDP of four preceding 
Table 10. FYR Macedonia: Financial Soundness Indicators, 2004-08

\begin{tabular}{|c|c|c|c|c|c|}
\hline & 2004 & 2005 & 2006 & 2007 & 2008Q2 \\
\hline \multicolumn{6}{|l|}{ Capital adequacy } \\
\hline Regulatory capital/risk weighted assets & 23.0 & 21.3 & 18.3 & 17.0 & 15.6 \\
\hline Tier I capital/risk weighted assets & 27.4 & 24.3 & 18.9 & 15.7 & 14.0 \\
\hline \multicolumn{6}{|l|}{ Asset composition and quality } \\
\hline \multicolumn{6}{|l|}{ Sectoral loans to nonfinancial enterprises/total loans } \\
\hline Enterprises & 63.5 & 61.7 & 59.0 & 54.9 & 54.3 \\
\hline Households & 26.1 & 30.6 & 33.4 & 37.7 & 38.5 \\
\hline \multicolumn{6}{|l|}{ Foreign currency lending } \\
\hline Foreign currency lending/total credit to private sector & 20.0 & 25.4 & 26.3 & 24.6 & 23.2 \\
\hline Foreign currency indexed lending/total credit to private sector $1 /$ & 20.6 & 23.8 & 26.4 & 30.1 & 31.5 \\
\hline NPLs /gross loans $2 /$ & 17.0 & 15.0 & 11.2 & 7.5 & 6.9 \\
\hline NPLs net of provision /capital 2/ & 3.8 & 2.9 & 0.7 & -5.0 & -5.1 \\
\hline Large exposures/capital & 219.0 & 189.7 & 194.7 & 181.4 & 121.0 \\
\hline \multicolumn{6}{|l|}{ Connected lending } \\
\hline Banking system exposure to shareholders/capital & 7.4 & 4.3 & 5.2 & 5.6 & 3.2 \\
\hline Banking system equity participation/capital & 6.7 & 7.0 & 6.3 & 4.9 & 4.6 \\
\hline \multicolumn{6}{|l|}{ Earning and profitability } \\
\hline ROAA 3/ & 0.6 & 1.2 & 1.8 & 1.8 & 2.2 \\
\hline ROAE 3/ & 3.1 & 7.5 & 12.3 & 15.0 & 19.1 \\
\hline Interest margin/gross income & 49.6 & 53.8 & 57.1 & 57.0 & 59.4 \\
\hline Noninterest expenses/gross income & 80.5 & 68.1 & 63.6 & 60.3 & 59.1 \\
\hline Personnel expenses/noninterest expenses & 39.2 & 42.1 & 41.1 & 38.4 & 38.2 \\
\hline \multicolumn{6}{|l|}{ Interest rate spreads (in percentage points) } \\
\hline Local currency & 5.5 & 6.5 & 6.3 & 4.5 & 3.8 \\
\hline Foreign currency & 5.6 & 6.5 & 6.7 & 6.5 & 5.9 \\
\hline Interbank market & 6.9 & 8.7 & 4.9 & 3.1 & 4.6 \\
\hline \multicolumn{6}{|l|}{ Liquidity } \\
\hline Highly liquid assets/total assets $4 /$ & 12.0 & 14.9 & 17.7 & 20.6 & 17.8 \\
\hline Highly liquid assets/total short-term liabilities $5 /$ & 17.8 & 22.0 & 25.6 & 28.7 & 25.1 \\
\hline Customer deposits/total (noninterbank) loans & 143.4 & 142.3 & 137.1 & 128.3 & 118.5 \\
\hline $\begin{array}{l}\text { Foreign currency deposits/total deposits (from the balance sheet- } \\
\text { excluding deposits of banks) }\end{array}$ & 54.4 & 55.7 & 51.8 & 44.5 & 45.3 \\
\hline Central bank credit to banks/bank liabilities $6 /$ & 0.9 & 0.7 & 1.3 & 2.0 & 0.5 \\
\hline \multicolumn{6}{|l|}{ Sensitivity to market risk } \\
\hline Net foreign exchange position /capital & 52.2 & 51.6 & 47.0 & 38.2 & 29.9 \\
\hline
\end{tabular}

Source: NBRM's Financial Stability, Banking Regulations and Methodology Department.

1/ The ratio differs from that used in the monetary survey due to different definitions.

$2 /$ Includes only loans to nonfinancial sector.

3/ Adjusted for unallocated provisions for potential loan losses.

4/ Highly liquid assets are defined as cash and balances with the NBRM, NBRM bills, and accounts with foreign banks. Large drop in 2006 compared to 2005 is due to change in methodology.

5/ Short-term liabilities are defined as deposits and other liabilities with a maturity of one year or less. Large drop in 2006 compared to 2005 is due to change in methodology.

6/ The increase in 2006 is due to loans channeled through NBRM, not NBRM credit to banks. 
Table 11. FYR Macedonia: Main Findings of the 2008 FSAP Update

Since the 2003 FSAP, the Macedonian financial sector has strengthened and deepened. Favorable macroeconomic conditions helped the banking sector grow by more than 20 percent annually during 2004-07. However, the non-bank financial sector is still small. All key recommendations of the 2003 FSAP have been at least partially implemented.

Rapid credit growth is a concern, particularly given the recent deterioration in the current account. Credit growth has been led by lending to households. Lending has primarily been financed by customer deposits, but increasingly by banks drawing down their assets held abroad. Given their net creditor position, Macedonian banks have not been directly effected by the international financial market turmoil (Box 1).

Stress test results suggest the banking system is sufficiently capitalized to withstand a wide range of shocks, though the large banks face some vulnerability to credit risk. This is not surprising as they dominate the market. In addition, similar to the region, much lending is either denominated or linked to foreign currencies. This transforms banks' currency risk into credit risk, as most borrowers are unhedged. Also, most loans are adjustable rate, so banks do not carry interest rate risk.

Bank supervision has improved significantly. The new Banking Law enacted in 2007 was a major improvement. Its provisions helped the authorities close a small problem bank in 2007.

Most elements of a financial safety net are in place with the establishment of a lender of last resort facility since the 2003 FSAP.

Key recommendations of the FSAP update include:

- Use prudential measures to limit household credit growth and improve credit quality. The NBRM's controls have proved ineffective, with banks exceeding the limits.

- Monitor trends in asset quality and strengthen stress testing, particularly for credit risk.

- The authorities should pass new legislation, consistent with the Constitution, that restores the NBRM's supervisory powers in resolving problem banks, and ensuring that bank owners are "fit and proper".

- Improve financial safety net arrangements by developing contingency plans and conducting crisis simulation exercises.

- Establish the new insurance supervisory agency-failure to do so means there is now a regulatory and supervisory vacuum.

- Strengthen the supervision and enforcement capacity of Macedonian Securities Exchange Commission.

- The pension supervisory agency should introduce risk-based supervision. 
Table 12. External Debt Sustainability Framework (Baseline), 2003-13

(In percent of GDP, unless otherwise indicated)

\begin{tabular}{|c|c|c|c|c|c|c|c|c|c|c|c|c|}
\hline & \multicolumn{5}{|c|}{ Actual } & \multicolumn{7}{|c|}{ Projections } \\
\hline & 2003 & 2004 & 2005 & 2006 & 2007 & 2008 & 2009 & 2010 & 2011 & 2012 & 2013 & Debt-stabilizing \\
\hline & & & & & & & & & & & & current account $6 /$ \\
\hline Baseline: External debt & 46.0 & 47.9 & 53.8 & 49.1 & 48.4 & 54.2 & 59.0 & 65.2 & 70.0 & 74.2 & 77.2 & -6.0 \\
\hline Change in external debt & 7.8 & 1.9 & 6.0 & -4.7 & -0.7 & 5.8 & 4.8 & 6.2 & 4.8 & 4.2 & 3.0 & \\
\hline Identified external debt-creating flows $(4+8+9)$ & 0.9 & 3.0 & -3.6 & -10.4 & -7.9 & 7.1 & 7.0 & 5.2 & 5.2 & 5.0 & 3.7 & \\
\hline Current account deficit, excluding interest payments & 2.9 & 7.5 & 1.6 & -0.5 & 1.5 & 12.4 & 11.6 & 10.3 & 9.9 & 8.8 & 7.6 & \\
\hline Deficit in balance of goods and services & -93.5 & -101.2 & -107.0 & -113.3 & -128.7 & -144.1 & -139.1 & -139.5 & -140.9 & -141.0 & -140.4 & \\
\hline Exports & 37.5 & 39.5 & 44.0 & 46.8 & 54.1 & 58.4 & 56.4 & 57.0 & 58.0 & 58.8 & 59.2 & \\
\hline Net non-debt creating capital inflows (negative) & -2.1 & -3.2 & -2.7 & -7.0 & -6.3 & -4.5 & -4.3 & -4.3 & -3.9 & -3.7 & -3.5 & \\
\hline Automatic debt dynamics $1 /$ & 0.1 & -1.3 & -2.5 & -2.9 & -3.2 & -0.8 & -0.3 & -0.8 & -0.8 & -0.2 & -0.3 & \\
\hline Contribution from nominal interest rate & 1.2 & 0.9 & 1.0 & 1.4 & 1.5 & 1.5 & 1.7 & 1.9 & 2.2 & 2.4 & 2.5 & \\
\hline Contribution from real GDP growth & -1.0 & -1.8 & -1.8 & -2.0 & -2.2 & -2.4 & -2.0 & -2.7 & -3.0 & -2.6 & -2.8 & \\
\hline Contribution from price and exchange rate changes $2 /$ & -0.1 & -0.4 & -1.7 & -2.3 & -2.5 & $\ldots$ & $\ldots$ & $\ldots$ & $\ldots$ & $\ldots$ & $\ldots$ & \\
\hline Residual, incl. change in gross foreign assets (2-3) 3 / & 6.9 & -1.1 & 9.6 & 5.7 & 7.2 & -1.3 & -2.2 & 1.0 & -0.4 & -0.8 & -0.7 & \\
\hline External debt-to-exports ratio (in percent) & 122.6 & 121.2 & 122.3 & 104.8 & 89.3 & 92.7 & 104.6 & 114.3 & 120.5 & 126.2 & 130.4 & \\
\hline Gross external financing need (in billions of euros) 4/ & 513 & 1,093 & 913 & 1,104 & 1,367 & 2,241 & 2,638 & 2,998 & 3,441 & 3,816 & 4,134 & \\
\hline In percent of GDP & 12.5 & 25.3 & 19.5 & 21.7 & 24.4 & 35.5 & 38.2 & 39.8 & 42.0 & 43.5 & 44.1 & \\
\hline \multicolumn{13}{|l|}{ Key Macroeconomic Assumptions Underlying Baseline } \\
\hline Real GDP growth (in percent) & 2.8 & 4.1 & 4.1 & 4.0 & 5.0 & 5.5 & 4.0 & 5.0 & 5.0 & 4.0 & 4.0 & \\
\hline GDP deflator in euros (change in percent) & 0.1 & 0.9 & 3.7 & 4.4 & 5.3 & 6.7 & 5.0 & 4.0 & 3.5 & 3.0 & 2.8 & \\
\hline Nominal external interest rate (in percent) & 3.1 & 2.1 & 2.2 & 2.7 & 3.4 & 3.5 & 3.4 & 3.5 & 3.6 & 3.7 & 3.5 & \\
\hline Growth of exports of goods \& services (euro terms, in percent) & 6.7 & 11.1 & 20.5 & 15.6 & 27.6 & 21.6 & 5.3 & 10.4 & 10.6 & 8.4 & 7.7 & \\
\hline Growth of imports goods \& services (euro terms, in percent) & -0.6 & 16.1 & 10.3 & 14.8 & 23.8 & 29.3 & 5.4 & 9.0 & 9.1 & 6.4 & 5.5 & \\
\hline Current account balance, excluding interest payments & -2.9 & -7.5 & -1.6 & 0.5 & -1.5 & -12.4 & -11.6 & -10.3 & -9.9 & -8.8 & -7.6 & \\
\hline Net non-debt creating capital inflows & 2.1 & 3.2 & 2.7 & 7.0 & 6.3 & 4.5 & 4.3 & 4.3 & 3.9 & 3.7 & 3.5 & \\
\hline
\end{tabular}

1/ Derived as $[r-g-r(1+g)+e a(1+r)] /(1+g+r+g r)$ times previous period debt stock, with $r=$ nominal effective interest rate on external debt; $r=$ change in domestic GDP deflator in euro terms, $g=$ real GDP growth rate, $\mathrm{e}=$ nominal appreciation (increase in euro value of domestic currency), and $\mathrm{a}=$ share of domestic-currency denominated debt in total external debt.

$2 /$ The contribution from price and exchange rate changes is defined as $[-\rho(1+g)+\varepsilon \alpha(1+r)](1+g+\rho+g \rho)$ times previous period debt stock. $\rho$ increases with an appreciating domestic currency ( $\varepsilon>0)$ and rising inflation (based on GDP deflator).

3/ For projection, line includes the impact of price and exchange rate changes.

4/ Defined as current account deficit, plus amortization on medium- and long-term debt, plus short-term debt at end of previous period.

5/ The key variables include real GDP growth; nominal interest rate; euro deflator growth; and both non-interest current account and non-debt inflows in percent of GDP.

6/ Long-run, constant balance that stabilizes the debt ratio assuming that key variables (real GDP growth, nominal interest rate, euro deflator growth, and non-debt inflows in percent of GDP) remain at

their levels of the last projection year. 
Table 13. FYR Macedonia: Fiscal Debt Sustainability Framework (Baseline), 2003-13

(In percent of GDP, unless otherwise indicated)

\begin{tabular}{|c|c|c|c|c|c|c|c|c|c|c|c|c|c|c|}
\hline & \multicolumn{5}{|c|}{ Actual } & \multicolumn{9}{|c|}{ Projection } \\
\hline & 2003 & 2004 & 2005 & 2006 & 2007 & & & 2008 & 2009 & 2010 & 2011 & 2012 & 2013 & \multirow{3}{*}{$\begin{array}{c}\text { Debt-stabilizing } \\
\text { primary } \\
\text { balance } 9 / \\
-1.3\end{array}$} \\
\hline & & & & & & & & & & & & & & \\
\hline Public sector debt $1 /$ & 39.0 & 36.6 & 39.5 & 33.0 & 25.6 & & & 22.0 & 23.2 & 24.7 & 26.8 & 27.0 & 26.2 & \\
\hline Of which: foreign-currency denominated & 37.7 & 34.7 & 37.1 & 29.0 & 22.5 & & & 19.4 & 20.4 & 21.7 & 23.5 & 23.7 & 23.1 & \\
\hline Change in public sector debt & -4.0 & -2.4 & 3.0 & -6.6 & -7.4 & & & -3.5 & 1.1 & 1.5 & 2.0 & 0.2 & -0.7 & \\
\hline Identified debt-creating flows & -0.5 & -1.5 & -1.6 & -8.4 & -2.4 & & & -1.9 & 1.1 & 1.5 & 2.0 & 0.2 & -0.8 & \\
\hline Primary deficit & -1.0 & -1.3 & -1.2 & -0.5 & -1.5 & & & 0.8 & 2.3 & 2.8 & 3.3 & 1.3 & 0.3 & \\
\hline Revenue and grants & 38.4 & 36.5 & 35.2 & 32.9 & 34.3 & & & 36.8 & 34.5 & 33.8 & 33.3 & 33.0 & 33.0 & \\
\hline Primary (non-interest) expenditure & 37.4 & 35.2 & 34.0 & 32.5 & 32.8 & & & 37.6 & 36.8 & 36.6 & 36.6 & 34.3 & 33.3 & \\
\hline Automatic debt dynamics $2 /$ & 0.0 & -1.1 & -1.9 & -2.1 & -2.2 & & & -2.3 & -1.1 & -1.2 & -1.2 & -1.0 & -1.0 & \\
\hline Contribution from interest rate/growth differential 3/ & -0.2 & -1.1 & -1.8 & -2.1 & -2.2 & & & -2.3 & -1.1 & -1.2 & -1.2 & -1.0 & -1.0 & \\
\hline Of which: contribution from real interest rate & 1.0 & 0.4 & -0.4 & -0.7 & -0.8 & & & -1.0 & -0.3 & -0.2 & -0.1 & 0.0 & 0.0 & \\
\hline Of which: contribution from real GDP growth & -1.2 & -1.5 & -1.4 & -1.4 & -1.5 & & & -1.2 & -0.8 & -1.1 & -1.1 & -1.0 & -1.0 & \\
\hline Contribution from exchange rate depreciation $4 /$ & 0.1 & 0.0 & -0.1 & 0.0 & 0.0 & & & 0.0 & 0.0 & 0.0 & 0.0 & 0.0 & 0.0 & \\
\hline Other identified debt-creating flows & 0.6 & 0.9 & 1.5 & -5.9 & 1.3 & & & -0.4 & 0.0 & 0.0 & 0.0 & 0.0 & 0.0 & \\
\hline Privatization receipts (negative) & -0.3 & -0.2 & -0.2 & -6.5 & 0.2 & & & -0.9 & 0.0 & 0.0 & 0.0 & 0.0 & 0.0 & \\
\hline Recognition of implicit or contingent liabilities & 0.9 & 1.1 & 1.2 & 0.7 & 1.1 & & & 0.5 & 0.0 & 0.0 & 0.0 & 0.0 & 0.0 & \\
\hline Residual & -3.5 & -0.9 & 4.6 & 1.9 & -5.0 & & & 3.9 & 0.0 & 0.0 & 0.0 & 0.0 & 0.0 & \\
\hline Public sector debt-to-revenue ratio $1 /$ & 101.5 & 100.2 & 112.3 & 100.3 & 74.6 & & & 59.9 & 67.2 & 73.1 & 80.3 & 81.7 & 79.5 & \\
\hline $\begin{array}{l}\text { Gross trinancing need } 5 \text {, } \\
\text { In million euros }\end{array}$ & 3.2 & 2.4 & 3.1 & 8.4 & 5.4 & & & 7.0 & 9.0 & 10.1 & 10.7 & 9.1 & 8.5 & \\
\hline Key macroeconomic and fiscal assumptions & & & & & & Average & Deviation & & & & & & & Average \\
\hline Real GDP growth (in percent) & 2.8 & 4.1 & 4.1 & 4.0 & 5.0 & 2.3 & 3.3 & 5.5 & 4.0 & 5.0 & 5.0 & 4.0 & 4.0 & 4.6 \\
\hline Average nominal interest rate on public debt (in percent) $6 /$ & 2.6 & 2.5 & 2.7 & 2.7 & 2.8 & 2.9 & 0.5 & 2.7 & 3.6 & 3.5 & 3.2 & 3.0 & 3.0 & 3.2 \\
\hline Average real interest rate (nominal rate minus change in GDP deflator, in percent) & 2.4 & 1.1 & -1.1 & -1.6 & -2.3 & -0.2 & 1.6 & -4.2 & -1.4 & -0.6 & -0.2 & 0.0 & 0.0 & -1.1 \\
\hline Nominal appreciation (increase in U.S. dollar value of local currency, in percent) & -0.4 & 0.0 & 0.2 & 0.0 & 0.0 & -0.1 & 0.2 & 0.0 & 0.0 & 0.0 & 0.0 & 0.0 & 0.0 & 0.0 \\
\hline Inflation rate (GDP deflator, in percent) & 0.3 & 1.3 & 3.8 & 4.4 & 5.1 & 3.1 & 1.7 & 7.0 & 5.0 & 4.0 & 3.5 & 3.0 & 3.0 & 4.2 \\
\hline Growth of real primary spending (deflated by GDP deflator, in percent) & -1.5 & -2.0 & 0.6 & -0.9 & 6.1 & 2.8 & 6.1 & 20.8 & 1.8 & 4.4 & 5.0 & -2.6 & -2.6 & 4.5 \\
\hline Primary deficit & -1.0 & -1.3 & -1.2 & -0.5 & -1.5 & 0.4 & 2.6 & 0.8 & 2.3 & 2.8 & 3.3 & 1.3 & 0.3 & 1.8 \\
\hline A. Alternative Scenarios & & & & & & Stress & Tests for Public & Debt Rat & & & & & & $\begin{array}{c}\text { Debt-stabilizing } \\
\text { primary } \\
\text { balance } 9 /\end{array}$ \\
\hline A1. Key variables are at their historical averages in 2008-13 7/ & & & & & & & & 32.3 & 31.9 & 31.6 & 31.2 & 30.9 & 30.7 & -0.8 \\
\hline A2. No policy change (constant primary balance) in $2008-13$ & & & & & & & & 27.3 & 25.4 & 23.6 & 22.0 & 20.7 & 20.1 & -1.1 \\
\hline \multicolumn{15}{|l|}{ B. Bound Tests } \\
\hline B1. Real interest rate is at baseline plus one standard deviations & & & & & & & & 28.0 & 29.0 & 30.5 & 32.4 & 32.7 & 31.7 & -1.4 \\
\hline B2. Real GDP growth is at baseline minus one-half standard deviation & & & & & & & & 30.1 & 33.1 & 37.0 & 42.0 & 45.7 & 44.7 & -1.5 \\
\hline B3. Primary balance is at baseline minus one-half standard deviation & & & & & & & & 30.1 & 32.1 & 34.5 & 37.4 & 38.5 & 38.7 & -1.9 \\
\hline B4. Combination of B1-B3 using one-quarter standard deviation shocks & & & & & & & & 29.5 & 31.2 & 33.4 & 36.0 & 36.9 & 36.9 & -1.4 \\
\hline B5. One time 30 percent real depreciation in $20068 /$ & & & & & & & & 41.0 & 41.1 & 41.7 & 42.9 & 42.5 & 40.9 & -2.1 \\
\hline B6. 10 percent of GDP increase in other debt-creating flows in 2006 & & & & & & & & 36.7 & 37.1 & 37.9 & 39.3 & 39.0 & 37.8 & -2.0 \\
\hline
\end{tabular}

$1 /$ Consolidated central government gross debt.

2/ Derived as $[(r-p(1+g)-g+a e(1+r)] /(1+g+p+g p))$ times previous period debt ratio, with $r=$ interest rate; $p=$ growth rate of GDP deflator; $g=$ real GDP growth rate; $a=$ share of foreign-currency denominated debt; and $\mathrm{e}=$ nominal exchange rate depreciation (measured by increase in local currency value of U.S. dollar).

$3 /$ The real interest rate contribution is derived from the denominator in footnote $2 /$ as $r-\pi(1+g)$ and the real growth contribution as $-\mathrm{g}$.

4/ The exchange rate contribution is derived from the numerator in footnote $2 /$ as ae( $1+r)$.

5/ Defined as public sector deficit, plus amortization of medium and long-term public sector debt, plus short-term debt at end of previous period.

6/ Derived as nominal interest expenditure divided by previous period debt stock.

7/ The key variables include real GDP growth; real interest rate; and primary balance in percent of GDP.

8/ Real depreciation is defined as nominal depreciation (measured by percentage fall in dollar value of local currency) minus domestic inflation (based on GDP deflator).

9/ Assumes that key variables (real GDP growth, real interest rate, and other identified debt-creating flows) remain at the level of the last projection year. 
Table 14. FYR Macedonia: Composition of Central Government Debt, 2007-08

\begin{tabular}{|c|c|c|c|c|}
\hline & \multicolumn{2}{|c|}{2007} & \multicolumn{2}{|c|}{$20081 /$} \\
\hline & $\begin{array}{l}\text { Percent of } \\
\text { GDP }\end{array}$ & $\begin{array}{l}\text { Percent of } \\
\text { gorss debt }\end{array}$ & $\begin{array}{l}\text { Percent of } \\
\text { GDP }\end{array}$ & $\begin{array}{l}\text { Percent of } \\
\text { gorss debt }\end{array}$ \\
\hline Gross debt & 24.2 & 100.0 & 20.5 & 100.0 \\
\hline External debt & 15.7 & 64.8 & 13.7 & 67.1 \\
\hline Multilateral & 11.1 & 46.0 & 9.4 & 45.8 \\
\hline Bilateral & 1.2 & 5.1 & 1.6 & 7.8 \\
\hline Private & 3.3 & 13.7 & 2.8 & 13.5 \\
\hline Domestic & 8.5 & 35.2 & 6.7 & 32.9 \\
\hline Structural bonds & 7.1 & 29.2 & 5.5 & 27.1 \\
\hline Treasury bills and bonds & 1.4 & 6.0 & 1.2 & 5.8 \\
\hline NBRM deposits & 4.0 & 16.7 & 4.1 & 19.8 \\
\hline Net debt & 20.2 & 83.3 & 16.4 & 80.2 \\
\hline \multicolumn{5}{|l|}{ Memo items: } \\
\hline Fx-denominated debt & 22.5 & 92.8 & 16.8 & 81.8 \\
\hline Short term debt & 0.9 & 3.9 & 1.2 & 5.9 \\
\hline
\end{tabular}

Source: NBRM, MOF

1/ End-June 2008 outturn. 
Table 15. FYR Macedonia: Level and Composition of External Debt, 2004-08

\begin{tabular}{|c|c|c|c|c|c|}
\hline & 2004 & 2005 & 2006 & 2007 & 2008 \\
\hline Gross external debt (million euros) & 2,071 & 2,518 & 2,495 & 2,712 & 3,419 \\
\hline Gross external debt (percent of GDP) & 47.9 & 53.9 & 49.1 & 48.4 & 54.2 \\
\hline \multicolumn{6}{|l|}{ Maturity structure } \\
\hline Medium-Long-Term (percent of total) & 72.0 & 72.5 & 71.3 & 62.6 & 58.4 \\
\hline Short-Term share (percent of total) & 28.0 & 27.5 & 28.7 & 37.4 & 41.6 \\
\hline \multicolumn{6}{|l|}{ Creditor } \\
\hline Official (percent of total) & 44.2 & 39.8 & 38.8 & 29.0 & 24.4 \\
\hline Private sector share (percent of total) & 55.8 & 60.2 & 61.2 & 71.0 & 75.6 \\
\hline \multicolumn{6}{|l|}{ Debtor } \\
\hline Public (percent of total) & 58.0 & 58.7 & 50.6 & 39.1 & 32.8 \\
\hline Private (percent of total) & 42.0 & 41.3 & 49.4 & 60.9 & 67.2 \\
\hline
\end{tabular}

Source: NBRM, MOF 
Table 16. FYR Macedonia: Rankings of Selected Competitiveness and Structural Indicators (0=lowest, 100=best) 1/

\begin{tabular}{|c|c|c|c|c|c|c|c|c|}
\hline & \multicolumn{2}{|c|}{ Macedonia } & \multicolumn{4}{|c|}{ Best performers $2 /$} & \multicolumn{2}{|c|}{ Distance 3/ } \\
\hline & 2006 & 2007 & Country & 2006 & Country & 2007 & 2006 & 2007 \\
\hline World Bank Doing Business survey & 46 & 58 & Estonia & 90 & Estonia & 90 & -44 & -33 \\
\hline Starting a business & 54 & 88 & Romania & 92 & Estonia & 89 & -38 & -1 \\
\hline Dealing with licenses & 43 & 57 & Estonia & 93 & Estonia & 92 & -51 & -35 \\
\hline Employing workers & 29 & 28 & Bulgaria & 67 & Czech Rep. & 69 & -38 & -41 \\
\hline Registering property & 51 & 49 & Lithuania & 98 & Lithuania & 98 & -47 & -49 \\
\hline Getting credit & 75 & 73 & Slovak Rep. & 93 & Slovak Rep. & 96 & -19 & -23 \\
\hline Protecting investors & 54 & 53 & Slovenia & 89 & Slovenia & 89 & -35 & -36 \\
\hline Paying taxes & 42 & 44 & Estonia & 82 & Latvia & 89 & -40 & -44 \\
\hline Trading across borders & 45 & 60 & Estonia & 96 & Estonia & 96 & -51 & -37 \\
\hline Enforcing contracts & 53 & 53 & Latvia & 98 & Latvia & 98 & -45 & -46 \\
\hline Closing a business & 29 & 29 & Lithuania & 82 & Lithuania & 83 & -53 & -54 \\
\hline \multicolumn{9}{|l|}{ World Economic Forum } \\
\hline Global Competitiveness & 71 & 66 & Estonia & 86 & Estonia & 84 & -15 & -18 \\
\hline Institutions & 52 & 54 & Estonia & 78 & Estonia & 77 & -26 & -23 \\
\hline Infrastructure & 43 & 44 & Estonia & 72 & Estonia & 66 & -28 & -22 \\
\hline Macroeconomic stability & 81 & 77 & Estonia & 86 & Estonia & 89 & -5 & -12 \\
\hline Health and primary education & 93 & 87 & Slovenia & 98 & Slovenia & 94 & -5 & -7 \\
\hline Higher education and training & 64 & 63 & Estonia & 84 & Estonia & 86 & -21 & -23 \\
\hline Goods market efficiency & 66 & 65 & Estonia & 88 & Estonia & 85 & -22 & -20 \\
\hline Labor market efficiency & $\ldots$ & 68 & & $\ldots$ & Slovak Rep. & 83 & $\ldots$ & -16 \\
\hline Financial market sophistication & 56 & 64 & Czech Rep. & 79 & Estonia & 82 & -23 & -18 \\
\hline Technological readiness & 45 & 47 & Estonia & 88 & Estonia & 86 & -43 & -39 \\
\hline \multicolumn{9}{|l|}{ Transparency international } \\
\hline Corruption Perception Index & 27 & 33 & Estonia & 67 & Slovenia & 66 & -40 & -33 \\
\hline EBRD transition indicators & 72 & 73 & & 92 & & 92 & -21 & -20 \\
\hline Large scale privatization & 77 & 77 & & 92 & & 92 & -15 & -15 \\
\hline Small scale privatization & 92 & 92 & & 100 & & 100 & -8 & -8 \\
\hline Enterprise restructuring & 62 & 62 & & 85 & & 85 & -23 & -23 \\
\hline Price liberalization & 100 & 100 & & 100 & & 100 & 0 & 0 \\
\hline Trade and foreign exchange system & 100 & 100 & & 100 & & 100 & 0 & 0 \\
\hline Competition policy & 46 & 54 & & 85 & & 85 & -39 & -31 \\
\hline Banking reform & 62 & 62 & & 92 & & 92 & -31 & -31 \\
\hline Nonbank financial institutions & 54 & 54 & & 92 & & 92 & -39 & -39 \\
\hline Overall infrastructure reform & 54 & 54 & & 85 & & 85 & -31 & -31 \\
\hline
\end{tabular}

Sources: EBRD; Transparency International; World Bank; World Economic Forum; and IMF staff calculations.

1/ For comparability, all indices have been normalized so that they range from 0 (lowest) to 100 (best).

2/ Country name and index of best performers among: Albania, Bosnia-Herzegovina, Bulgaria, Croatia, Czech Republic, Estonia, Hungary, Latvia, Lithuania, FYR Macedonia, Montenegro, Poland, Romania, Serbia, Slovak Republic, and Slovenia. Country names are not shown for EBRD transition indicators due to the presence of multiple entries.

3/ Distance of Macedonia from best performer for each index. 


\section{INTERNATIONAL MONETARY FUND \\ FORMER YUGOSLAV REPUBLIC OF MACEDONIA \\ Staff Report for the 2008 Article IV Consultation \\ Information Annexes}

Prepared by the European Department

(In consultation with other departments)

November 11, 2008

Contents

Page

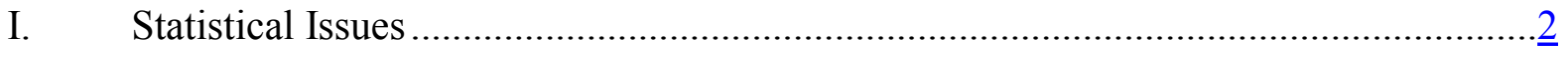

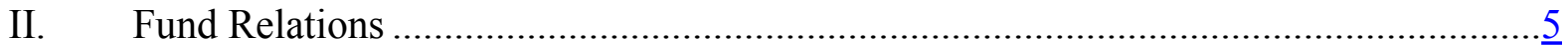

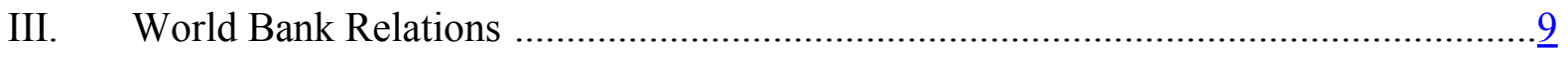




\section{Annex I-FYR Macedonia: Statistical Issues}

1. Data provision has some shortcomings, but is broadly adequate for surveillance. The most affected areas are: national accounts, government finance statistics, and balance of payments. Macedonia's plans for improving its statistical system are posted in the Fund's DSBB website in line with the General Data Dissemination System (GDDS) framework. A data ROSC was prepared and published in 2004.

\section{Real Sector Statistics}

2. Despite recent improvements, GDP statistics continue to be affected by large discrepancies between the official quarterly and annual GDP estimates, and between these and the behavior of a variety of indirect economic indicators. Further improvements in production and expenditure GDP estimates are needed to better inform policy makers and markets about economic developments. The State Statistics Office (SSO) implementation of STA recommendations has been slow mainly due to a heavy work load, capacity constraints, and lack of appropriate data. An STA peripatetic statistical advisor made several visits in 2008 to provide hands-on assistance to improve the methodology used by the SSO. A new quarterly GDP series by production and expenditure, based on an improved methodology, was published in June 2008. These data are now available from the first quarter of 2006 although there are plans to compile backward revisions for a longer series.

3. Employment data from the company survey continue to be unreliable, but the timeliness of unemployment and labor force data has been improved as the labor force survey is now conducted on a quarterly basis (compared to annual surveys in the past). Wage data suffer from the volatility of wage arrears payments.

\section{External Sector Statistics}

4. The compilation and coverage of balance of payments statistics have improved in recent years. Following the 2004 data ROSC mission and the STA mission in late 2006 most recommendations were implemented. One important weakness in the BOP statistics relates to private transfers. The weaknesses have stemmed from the assumption that most of the foreign currency exchanged into denars in the foreign exchange bureaus reflects private transfers by migrants. The 2006 STA mission utilized a 2002 private survey of migrants to estimate private transfers and allocated them to the current and capital accounts. The National Bank of the Republic of Macedonia (NBRM) is currently completing a more comprehensive follow-up survey, which will form the basis of new adjustments (the mission recommended that such surveys be conducted every five years going forward, to ensure that the main assumptions remained valid).

\section{Government Finance Statistics}

5. The consolidated central government data are affected by unreliable source data on extra-budgetary funds, hospital arrears, and special revenue accounts, including foreign 
financed projects. In addition, the consolidated general government data are affected by unreliable source data on local governments. Macedonia does not report government finance statistics to the Fund for publication in either the Government Finance Statistics Yearbook (GFSMY) or the International Financial Statistics (IFS). The October-November 2007 government finance statistics (GFS) pilot study mission to promote the methodology of the GFSM 2001 focused on bridging the statistics reported to the European Department to the analytical framework of the GFSM 2001 and producing a financial balance sheet for the central government. The mission identified serious data gaps in the government accounts.

\section{Monetary and Financial Statistics}

6. Monetary and financial statistics are reported to the Fund on a regular basis, although in the past they have been subject to concerns regarding inconsistencies, accuracy and reliability. To address these issues, STA provided technical assistance in April 2005 based on the findings of the 2004 data ROSC. The mission recommendations include: (i) improved institutional coverage of monetary statistics through the inclusion of savings houses in the reporting of other depository corporations; (ii) the collection of more disaggregated data in both the NBRM and commercial banks' balance sheets to improve the classification of accounts by economic sector; (iii) improved data consistency through reconciliation of loan data among various sectors; (iv) the publication of improved interest rate data in IFS; and (v) the establishment of a well-defined policy on data revisions in line with best international practice. The NBRM has since begun to implement these improvements. The regular publication of lending and deposit interest rates of various maturities and currency-type has been an important step forward. In early 2008, the NBRM began reporting monetary data to the Fund using the Standardized Report Forms. 
FYR MACEDONIA: TABLE OF COMMON INDICATORS REQUIRED FOR SURVEILLANCE

(as of October 29, 2008)

\begin{tabular}{|c|c|c|c|c|c|c|c|}
\hline & & Date & Frequency & Frequency & Frequency & \multicolumn{2}{|c|}{ Memo Items: } \\
\hline & $\begin{array}{c}\text { latest } \\
\text { observation }\end{array}$ & received & Data $^{7}$ & $\begin{array}{c}\text { of } \\
\text { Reporting }\end{array}$ & $\begin{array}{c}\text { of } \\
\text { publication }^{7}\end{array}$ & $\begin{array}{l}\text { Data Quality - } \\
\text { Methodological } \\
\text { soundness }\end{array}$ & $\begin{array}{l}\text { Data Quality- } \\
\text { Accuracy and } \\
\text { reliability }\end{array}$ \\
\hline Exchange Rates & Sept. 08 & $10 / 17 / 08$ & $\mathrm{D}$ and $\mathrm{M}$ & $\mathrm{W}$ and $\mathrm{M}$ & $\mathrm{D}$ and $\mathrm{M}$ & & \\
\hline $\begin{array}{l}\text { International Reserve Assets and Reserve Liabilities of the Monetary } \\
\text { Authorities } 1\end{array}$ & $07 / 31 / 08$ & $08 / 20 / 08$ & M & M & M & & \\
\hline Reserve/Base Money & Aug. 08 & $10 / 01 / 08$ & $\mathrm{D}$ and $\mathrm{M}$ & $\mathrm{W}$ and $\mathrm{M}$ & M & \multirow{4}{*}{$\mathrm{O}, \mathrm{LO}, \mathrm{LO}, \mathrm{O}$} & \multirow{4}{*}{$\mathrm{O}, \mathrm{LO}, \mathrm{O}, \mathrm{O}, \mathrm{O}$} \\
\hline Broad Money & Aug. 08 & $10 / 01 / 08$ & M & M & M & & \\
\hline Central Bank Balance Sheet & Aug. 08 & $10 / 01 / 08$ & M & M & M & & \\
\hline Consolidated Balance Sheet of the Banking System & Aug. 08 & $10 / 01 / 08$ & M & M & M & & \\
\hline Interest Rates $^{2}$ & Aug. 08 & $10 / 01 / 08$ & M & M & M & & \\
\hline Consumer Price Index & Sept. 2008 & $10 / 22 / 08$ & M & M & M & $\mathrm{O}, \mathrm{O}, \mathrm{O}, \mathrm{LO}$ & $\mathrm{LO}, \mathrm{O}, \mathrm{LNO}, \mathrm{O}, \mathrm{LO}$ \\
\hline $\begin{array}{l}\text { Revenue, Expenditure, Balance and Composition of Financing }{ }^{3}-\text { General } \\
\text { Government }{ }^{4}\end{array}$ & $06 / 30 / 08$ & 08/15/08 & Q & Q & Q & \multirow[b]{2}{*}{ LO, LNO, LO, O } & \multirow[b]{2}{*}{$\begin{array}{l}\text { LO, LO, LO, LO, } \\
\text { LNO }\end{array}$} \\
\hline $\begin{array}{l}\text { Revenue, Expenditure, Balance and Composition of Financing }{ }^{3}-\text { Central } \\
\text { Government }\end{array}$ & $06 / 30 / 08$ & 08/15/08 & Q & Q & Q & & \\
\hline $\begin{array}{l}\text { Stocks of Central Government and Central Government-Guaranteed } \\
\text { Debt }^{5}\end{array}$ & $06 / 30 / 08$ & $08 / 15 / 08$ & M & M & I & & \\
\hline External Current Account Balance & May 2008 & 08/19/08 & M & M & M & \multirow[b]{2}{*}{$\mathrm{O}, \mathrm{LO}, \mathrm{O}, \mathrm{LO}$} & \multirow[b]{2}{*}{$\mathrm{LO}, \mathrm{O}, \mathrm{LO}, \mathrm{O}, \mathrm{LO}$} \\
\hline Exports and Imports of Goods and Services & Jun 2008 & 08/14/08 & M & M & M & & \\
\hline GDP/GNP & Mar 2008 & $06 / 24 / 08$ & Q & Q & Q & $\mathrm{O}, \mathrm{LO}, \mathrm{O}, \mathrm{LO}$ & $\mathrm{LO}, \mathrm{O}, \mathrm{LNO}, \mathrm{O}, \mathrm{O}$ \\
\hline Gross External Debt & $12 / 30 / 07$ & $03 / 31 / 08$ & Q & $\mathrm{Q}$ & Q & & \\
\hline International Investment Position ${ }^{6}$ & 2006 & $05 / 23 / 08$ & A & A & A & & \\
\hline
\end{tabular}

${ }^{1}$ Includes reserve assets pledged or otherwise encumbered as well as net derivative positions.

${ }^{2}$ Both market-based and officially-determined, including discount rates, money market rates, rates on treasury bills, notes and bonds.

${ }^{3}$ Foreign, domestic bank, and domestic nonbank financing.

${ }^{4}$ The general government consists of the central government (budgetary funds, extra budgetary funds, and social security funds) and state and local governments.

${ }^{5}$ Currency and maturity composition is reported only on request.

${ }^{6}$ Includes external gross financial asset and liability positions vis-à-vis nonresidents.

${ }^{7}$ Daily (D), Weekly (W), Monthly (M), Quarterly (Q), Annually (A), Irregular (I); Not Available (NA).

${ }^{8}$ Reflects the assessment provided in the data ROSC or the Substantive Update (published on September 29, 2004, and based on the findings of the mission that took place during February 18 - March 3, 2004) for the dataset corresponding to the variable in each row. The assessment indicates whether international standards concerning concepts and definitions, scope, classification/sectorization, and basis for recording are fully observed (O), largely observed (LO), largely not observed (LNO), or not observed (NO).

${ }^{9}$ Same as footnote 8 , except referring to international standards concerning source data, assessment and validation of source data,, statistical techniques, assessment and validation of intermediate data and statistical outputs, and revision studies. 


\section{Annex II-FYR Macedonia: Fund Relations}

(as of September 30, 2008)

Mission. Skopje, September 10-22, 2008. Press statement is available at: http://www.imf.org/external/np/sec/pr/2008/pr08214.htm

Staff team. Mark Griffiths (head), Pablo Lopez-Murphy and Chuling Chen (all EUR), Salim Darbar (MCM), Peter Dohlman (PDR), and Bert van Selm (Resident Representative).

Discussions. The staff team met Deputy Prime Minister Stavreski, Finance Minister Slaveski, National Bank of the Republic of Macedonia Governor Gošev, other senior officials, and representatives of the banking, business, political and international communities.

Stand-By Arrangement. The Fund had supported FYR Macedonia's economic program with a three-year SDR 51.68 million Stand-By arrangement (75 percent of quota). SDR 10.5 million was purchased initially but this, and earlier outstanding amounts, have been repaid. The program expired in August 2008.

Publication. The Macedonian authorities have not yet decided on the publication of this staff report.

I. Membership Status:

II. General Resources Account:

Quota

Fund holdings of currency

Reserve Position

III. SDR Department:

Net cumulative allocation

Holdings
Joined 12/14/92; Article VIII

$\begin{array}{rr}\text { SDR Million } & \text { Percent of Quota } \\ 68.90 & 100.00 \\ 68.90 & 100.00 \\ 0.00 & 0.00\end{array}$

$\underline{\text { SDR Million }}$

8.38

0.94
Percent of Allocation

100.00

11.19

IV. Outstanding Purchases and Loans: None 
V. Latest Financial Arrangements:

$\begin{array}{lcccc}\text { Type } & \begin{array}{c}\text { Approval } \\ \text { Date }\end{array} & \begin{array}{c}\text { Expiration } \\ \text { Date }\end{array} & \begin{array}{c}\text { Amount Approved } \\ \text { (SDR Million) }\end{array} & \begin{array}{c}\text { Amount Drawn } \\ \text { (SDR Million) }\end{array} \\ \text { Stand-By } & 08 / 31 / 2005 & 08 / 30 / 2008 & 51.68 & 10.50 \\ \text { Stand-By } & 04 / 30 / 2003 & 08 / 15 / 2004 & 20.00 & 20.00 \\ \text { EFF } & 11 / 29 / 2000 & 11 / 22 / 2001 & 24.12 & 1.15\end{array}$

VI. $\quad$ Projected Payments to the Fund (Expectations Basis) ${ }^{\mathbf{1}}$

(SDR million; based on existing use of resources and present holdings of SDRs):

\begin{tabular}{llll}
\multicolumn{5}{c}{ Forthcoming } \\
\hline 2008 & 2009 & $2010 \quad 2011$ & 2012
\end{tabular}

Principal

$\begin{array}{llllll}\text { Charges/Interest } \quad \underline{0.05} & \underline{0.19} & \underline{0.19} & \underline{0.19} & \underline{0.19}\end{array}$

$\begin{array}{llllll}\text { Total } & \underline{0.05} & \underline{0.19} & \underline{0.19} & \underline{0.19} & \underline{0.19}\end{array}$

VII. Safeguards Assessments:

An update was completed on February 28, 2006 with respect to the current StandBy Arrangement. The previous assessment was completed in April 2003. The update found that the NBRM had taken steps to strengthen its safeguards framework and recommendations from the earlier assessment had been implemented. Notwithstanding this progress, the report made recommendations in the reporting and audit areas, including: (i) review by the NBRM internal audit function of processes for compiling monetary data reported to the Fund under the program; and (ii) completion of annual external audits on a timely basis as prescribed by the central bank law. The NBRM has started to conduct internal audit reviews on the processes for compiling monetary data reported to the Fund.

\section{Exchange Arrangement:}

The currency of the FYR Macedonia is the denar. The FYR Macedonia maintains a managed floating exchange rate system with a de facto peg to the Euro.

Households can transact only through commercial banks or through foreign exchange bureaus that act as agents of banks; enterprises can transact through the banking system. The reserve requirement on all foreign currency deposits is set at 10 percent.

\footnotetext{
${ }^{1}$ This schedule presents all currently scheduled payments to the IMF, including repayment expectations and repayment obligations. The IMF Executive Board can extend repayment expectations (within predetermined limits) upon request by the debtor country if its external payments position is not strong enough to meet the expectations without undue hardship or risk.
} 
At end-September 2008, the official exchange rate was 42.63 denars per U.S. dollar and 61.17 denars per euro. The FYR Macedonia has accepted the obligations of Article VIII, Sections 2, 3, and 4 with effect from June 19, 1998.

The FYR Macedonia had maintained an exchange restriction subject to the Fund's approval under Article VIII, Section 2(a) arising from restrictions imposed on the transferability of proceeds from current international transactions contained in former frozen foreign currency saving deposits. Retention of this restriction was approved by the Board on December 21, 2006 until December 31, 2007, but it has now been lifted.

IX. Article IV Consultations:

The first consultation with the FYR Macedonia was concluded in August 1993. The last consultation was concluded on July 28, 2006. The FYR Macedonia is on the standard consultation cycle.

X. Technical Assistance (since 2005):

\section{Purpose}

Government Finance Statistics

Balance of Payments Statistics

National Accounts Statistics

Export and Import Deflators

GFS 2001

Expenditure Rationalization

Central Bank Law

Tax Policy

National Accounts Statistics

Liquidity, Cash and Debt Management

Tax Administration

Balance of Payments Statistics

\section{Department Date}

STA

October 2008

STA

October 2008

STA

April 2007, January, May, September 2008

STA

December 2007

STA

November 2007

FAD July 2007

MCM

July 2007

FAD June 2007

STA

April 2007

$\mathrm{MCM}$

April 2007

FAD

October 2006

STA

October 2006 
Tax Policy

Government Finance Statistics

Banking Law

Banking Reform

Credit Growth

National Accounts

BOP Statistics

Tax Administration

Reserve Management

Monetary Statistics

\section{Resident Experts}

Banking Supervision

Tax Administration

Monetary Policies
FAD

STA

LEG, MCM

$\mathrm{MCM}$

MCM

STA

STA

FAD

MCM

STA

$\mathrm{MCM}$

FAD

MCM
September 2006

June 2006

June 2006

November 2005

October 2005

July 2005

July 2005

May 2005

May 2005

April 2005

May 2006-present

October 2006-present

October 2004-

April 2005

XI. FSAP Participation and ROSCs (since 2003)

Purpose

FSAP update

Fiscal ROSC

Data ROSC

FSAP
Department Date

MCM/WB March 2008

FAD February 2005

STA

February 2004

MCM/WB May 2003 and

June 2003

\section{Resident Representative}

The Fund has had a resident representative in Skopje since 1995. Mr. Bert van Selm has held this position since August 2006. 


\section{Annex III-FYR Macedonia: World Bank Relations ${ }^{1}$}

\section{A. Partnership in FYR Macedonia's Development Strategy}

1. The country has made considerable progress since independence, amid a highly unfavorable regional outlook during most of the 1990's and a domestic conflict in 2001. The Ohrid Framework Agreement, which ended the 2001 insurgency, brought a reasonable measure of stability to the country, despite continuing political tensions. The strategic priorities of the Government have included EU and NATO accession, implementation of the Ohrid Agreement and promoting growth and reducing unemployment and poverty. FYR Macedonia's progress is reflected perhaps most prominently in its candidacy for membership in the European Union.

2. Macroeconomic stability has been maintained since the mid-1990s. Fiscal discipline and the peg to the Euro helped maintain inflation at low levels for a decade. Government spending as a proportion of GDP has increased in the last two years, albeit from relatively low levels compared to the region. This, together with intensified structural reforms in recent years, has resulted in growth rates of around 4 percent since 2004. Stronger growth has been constrained by structural impediments and continuation of reforms is crucial if the country is to attract the investment needed to underpin more rapid growth and job creation.

3. The modest growth has been insufficient to trigger a more substantial reduction in the unemployment rate. In the second quarter of 2007, the unemployment rate was 35 percent, compared to 36.1 percent in the same period of 2006. At the same time, absolute poverty continues to affect around 20 percent of the population.

\section{B. World Bank Supported Reform}

4. Since FYR Macedonia joined the World Bank in 1993, 44 loans have been approved with a total value of approximately US $\$ 840$ million, out of which around 44 percent on concessional IDA terms. FYR Macedonia graduated fully from IDA in 2003 reflecting improved economic performance and credit-worthiness. In June 2007 the authorities pre-paid slightly less than half of the disbursed IBRD portfolio.

5. The World Bank's current program of assistance to FYR Macedonia is outlined in a Country Partnership Strategy discussed by the Board on March 27, 2007. Reflecting Government priorities, the CPS aims to accelerate FYR Macedonia's perspective to join the European Union by focusing on two pillars: (i) fostering job-creating economic growth, and increasing living standards for all, and (ii) improving public sector delivery and good governance. The CPS will employ a selected mix of investment and policy lending (up to a

\footnotetext{
${ }^{1}$ Prepared by World Bank staff.
} 
total high case lending scenario of US $\$ 280$ million over 4 years), along with a robust program of Analytical and Advisory Activities (AAA) work to support the CPS goals.

6. Over the last five years, World Bank support gradually shifted from support to the governance reforms agenda (Public Sector Management Adjustment Credit approved in 2002, and Public Sector Management Adjustment Loan II approved in 2004) towards reforms to improve the investment climate and promote growth and employment. Bank support for Government reform efforts is centered on a series of Programmatic Development Policy Loans (PDPLs), the first of which was approved by the Board in October 2005, shortly after IMF Board approval of the current Stand-By Arrangement (SBA). The second PDPL was approved by the Board on March 27, 2007 and the third and final PDPL is planned for the first half of 2008. The PDPLs support Government efforts to undertake judicial reform, labor market reform, financial sector reform, and business regulatory reform. Efforts to further strengthen public sector governance include an emphasis on further reform to improve transparency and efficiency in health sector spending, building the capacity of the civil service to permit more effective strategic prioritization, and support for the decentralization program being conducted under the umbrella of the Ohrid Framework Agreement.

8. The Development policy lending is supported by a series of specific investments to build capacity to implement priority reforms. On the governance and public administration side, a Health Sector Management Improvement project provides technical assistance and investment support to the broader health sector reform program; a Social Protection project supports reform in pension and social assistance reforms; and an Education project assists Government efforts to improve access and introduce stronger performance and equity measures in primary and secondary education financing. On the investment climate side, a Business Environment Reform and Institutional Strengthening (BERIS) project approved in June 2005 concentrates on building capacity to improve business entry, operations, and exit; as well as enhancing the competitiveness of the enterprise sector; and a Real Estate Cadastre and Registration project approved in early 2005 strengthens land markets and the use of real property as collateral for business investment by providing more secure title. A Legal and Judicial Reform project approved in mid May 2006 supports critical reforms in this area. Adjustment and investment lending has also been backed up by a comprehensive program of analytical work.

9. The Bank is also providing support to other sectors, including railways (Railways Reform project), energy sector (Energy Community in Southeast Europe project and Sustainable Energy GEF), agriculture (Agriculture Strengthening and Accession project) and trade facilitation (Trade and Transport Facilitation in Southeast Europe 2). 


\section{IMF-World Bank Collaboration in Specific Areas}

9. World Bank and IMF engagement in FYR Macedonia in recent years has been marked by a spirit of collaboration and close cooperation between the two institutions at all levels, as well as with the Government. Synergies between the Bank and IMF programs during the implementation of reforms reflect a strong degree of consensus between both institutions and the Government in regard to reform priorities. This close coordination has ensured that the SBA and the Bank program are mutually reinforcing.

10. Judicial reform is central to improving the business environment in FYR Macedonia and firmly establishing protection of creditor, contract and property rights. IMF SBA benchmarks to analyze and budget for the fiscal effects of judicial reform, enact amendments to the Bankruptcy Law, and amend the Law on Misdemeanors to allow administrative bodies to impose sanctions without prior court involvement complemented Bank supported reform efforts. Under the PDPL and the Legal and Judicial Reform project, the Bank is focusing on: reducing backlog and delays in court proceedings; improving the enforcement of court judgments; improving the regulatory and implementation framework for bankruptcy cases; and increasing the speed, transparency and fairness of administrative decisions.

11. Support for labor market reform also requires close coordination. A very rigid legislative framework governing labor relations as well as a high tax wedge contributed to a stagnant formal labor market, exceptionally high unemployment rate and a large informal sector. The Bank took the lead in supporting the new Law on Labor Relations adopted in July 2005 which eliminated the most burdensome features of the old law while the IMF has provided support in reducing the tax wedge and streamlining procedures.

12. Judicial and labor market reforms are being complemented by a range of other measures to strengthen the framework for business activity. The enactment and implementation of a new Business Registration Law and associated regulations has significantly reduced the costs and time of business entry. This has led to a 50 percent increase in new business registration in 2006. The Government is also focusing on reforms to reduce the burden of unnecessary regulations on businesses. This reform will streamline business licensing, permits and inspections. These continuing reforms are supported by the Bank's PDPL program as well as the BERIS project. Further actions to implement corporate governance and accounting and auditing reports on standards and codes (ROSCs) have been undertaken, including amendments to the Company Law and Securities Law, and the passage of a new Audit Law. The Bank and IMF have cooperated closely in supporting the capacity of the National Bank (NBRM) to supervise and regulate the banking sector, and to strengthen compliance with anti-money laundering and counter-terrorist financing requirements.

13. Reform of health sector financing is a key element of both the Bank and IMF programs. Health sector spending makes up 15 percent of Government expenditure and has 
historically been an area with significant fiduciary risks associated with pharmaceutical procurement and less than fully transparent operation of the Health Insurance Fund (HIF) and Health Care Institutions (HCIs). Prior actions and performance criteria in the SBA have reinforced the Bank's programs, which support efforts to further prioritize spending, improve cost-effectiveness, and strengthen mechanisms for pharmaceutical procurement.

15. Bank support for civil service reform, including strengthening institutional arrangements for strategic prioritization, complement IMF efforts to improve fiscal and budget management. Extending the principles underpinning civil service reform to the majority of Government employees will further strengthen meritocratic principles and the professionalism of the public sector. This would need to occur within the framework of the Ohrid Framework Agreement, and the associated provisions for the representation of minorities.

16. Substantial progress has been made in adopting the framework for decentralization, most recently with the graduation of more than half of the municipalities to the second phase as well as adoption of formulas for distribution of earmarked and block grants. While not directly involved in the design, the World Bank's and IMF's involvement ensured a fiscally sustainable progress in decentralization but further coordination will be required.

17. Most recently, the Bank and the Fund have cooperated closely on the energy sector dialogue. The Bank is assisting the counterparts in designing a plan that would ensure stable and affordable energy supply in the future, and the IMF SBA has supported this.

\section{Summary}

17. FYR Macedonia has made considerable progress in macroeconomic management and improving the transparency and operations of the public sector. Although continuing governance and macroeconomic challenges remain, there is broad consensus that a strong focus on structural reform must be sustained to overcome key impediments to growth and employment. This is reflected in both the IMF and Bank programs. The strong similarities between aspects of the IMF SBA and the Bank's proposed adjustment and investment lending program have considerable potential to generate synergies and complementarities. This, however, requires continuing strong collaboration between the Macedonian Government, the Bank and the IMF. 


\section{IMF Executive Board Concludes 2008 Article IV Consultation with the Former Yugoslav Republic of Macedonia}

On December 1, 2008, the Executive Board of the International Monetary Fund (IMF) concluded the Article IV consultation with the former Yugoslav Republic of Macedonia. ${ }^{1}$

\section{Background}

Growth has picked up, led by stronger domestic demand and increasing investment. In 2007 improved terms of trade and remittances boosted incomes and domestic demand. This raised growth to 5 percent. Though these favorable shocks have reversed, in the first half of 2008 growth increased to 6 percent (led by construction, wholesale and retail trade) while industrial production growth reached double digits. Strong investment growth, in part reflecting higher foreign direct investment (FDI), and the high unemployment rate, which is still around 35 percent, suggest few capacity constraints and considerable scope for continuing this favorable supply response. But compared to the region, past economic growth has been tepid, and there is plenty of room for catch up.

\footnotetext{
${ }^{1}$ Under Article IV of the IMF's Articles of Agreement, the IMF holds bilateral discussions with members, usually every year. A staff team visits the country, collects economic and financial information, and discusses with officials the country's economic developments and policies. On return to headquarters, the staff prepares a report, which forms the basis for discussion by the Executive Board. At the conclusion of the discussion, the Managing Director, as Chairman of the Board, summarizes the views of Executive Directors, and this summary is transmitted to the country's authorities. This PIN summarizes the views of the Executive Board as expressed during the December 1, 2008 Executive Board discussion based on the staff report.
}

Washington, D.C. 20431 • Telephone 202-623-7100 • Fax 202-623-6772 • www.imf.org 
Inflation has risen despite the exchange rate anchor, mainly because of external shocks. From 2002 to 2006 inflation averaged less than 1 percent, sometimes with periods of deflation. Inflation jumped to around 10 percent in early 2008 , similar to other countries in the region, largely because of oil and food price increases. Higher nominal wage increases prevented a fall in real incomes.

Through 2007 the sharp increase in foreign exchange reserves resulted in monetary policy easing. From 2005 to 2007, the central bank's gross reserves increased by $€ 400$ million (almost 7 percent of GDP). Though offset partially by sales of central bank bills, the central bank's purchases of foreign exchange increased the supply of denars. This pushed central bank bill rates below 5 percent and commercial bank lending rates to less than 10 percent. With competition intensifying, credit growth increased to almost 40 percent, stimulating domestic demand and imports, and also potentially increasing risks in the banking system. To contain these risks, in 2008 the central bank started to tighten monetary policy. The National Bank of the Republic of Macedonia (NBRM) has gradually increased central bank bill rates to 7 percent, raised capital requirements for overdrafts and credit card loans, and introduced controls on household credit growth.

In 2006 and 2007 the central government budget was broadly in balance, but fiscal policy is turning increasingly expansionary. Tax revenue increased despite substantial tax cuts, owing to improved tax administration, domestic demand growth (which boosts VAT), and a near-doubling of corporate income tax revenues. Fiscal policy plans for the remainder of 2008 and the medium-term are expansionary. For 2008, the fiscal deficit target of 1.5 percent of GDP in 2008 represents an expansion of 2.1 percent of GDP compared to 2007 . The government intends to raise the fiscal deficit in the coming years.

The current account deficit has widened sharply, and has become the main risk to continued growth and macroeconomic stability. Both the size of the current account deficit-around 14 percent of GDP projected for this year-and the speed of its deterioration are of concern. This deterioration has three main components: a rising trade deficit, falling private transfers, and lower net factor income due to a large telecom dividend payment. Indicators of external vulnerability, such as international reserve cover of imports, or of short-term foreign debt, have also weakened.

Recent international financial turmoil poses additional uncertainties. There has been little direct impact, since Macedonian banks do not seem exposed to subprime lending overseas and rely mainly on domestic deposits rather than international credit lines to fund lending. However, the indirect impact is likely to grow. A slowdown in the world economy could worsen the current account deficit through reduced export demand, falling export prices, and weaker remittances, and could also threaten growth. 


\section{Executive Board Assessment}

Executive Directors welcomed FYR Macedonia's strong economic growth, supported by improvements in the business climate and a surge in foreign direct investment. Progress has also been made in improving living standards and reducing unemployment. At the same time, Directors expressed concern about increasing macroeconomic and external vulnerabilities. The current account deficit has widened dramatically, as a result of worsening terms of trade and rapid increases in pensions and public sector wages, public investment, and household credit. While the direct impact of the global financial crisis on FYR Macedonia's financial sector has been limited so far, the indirect impact is growing. Export demand has started to fall, and lower foreign direct investment, portfolio investment, and remittances could create additional balance of payments pressures.

Against this background, Directors emphasized the need for fiscal discipline. They noted the role automatic stabilizers could play in reducing macroeconomic vulnerabilities. This could be facilitated by saving this year's revenue over-performance and limiting discretionary spending. Directors encouraged the authorities to reconsider plans for further increases in the fiscal deficit in 2009 and beyond. Reversing the planned fiscal expansion would help reduce external vulnerabilities, lessen the risk of a "sudden stop" in external financing in the event of an unanticipated shock, and reduce the burden on monetary policy. Directors welcomed the authorities' commitment to stand ready to adjust the fiscal stance should macroeconomic indicators deteriorate markedly.

Directors welcomed the recent increases in interest rates and measures to curb credit growth and slow down the deterioration of the current account deficit. They considered that, despite the constraints of the exchange rate peg, the central bank still has room for maneuver, and they welcomed, in this regard, the authorities' commitment to take further action as necessary. Directors encouraged the authorities to replace credit controls by an increase in reserve requirements or capital requirements on riskier loans. They stressed that the priority of monetary policy should remain to protect the exchange rate.

Directors agreed that the exchange rate peg has provided a useful nominal anchor and remains appropriate for FYR Macedonia's small, open economy. They highlighted the importance of disciplined macroeconomic policies and their timely adjustment in order to preserve external stability. They cautioned that pre-announcing expansionary fiscal deficit targets over the medium term could constrain the flexibility of fiscal policy in safeguarding the exchange rate peg. Directors emphasized the need for the authorities to remain vigilant on external borrowing, given the currently high level of external debt and the low reserve coverage.

Directors commended the authorities for significant progress in improving banking supervision. They noted that implementation of the Financial Sector Assessment Program (FSAP) update recommendations would further strengthen financial sector 
supervision and address gaps in nonbank supervision. Noting that residents' unhedged foreign exchange borrowing remains a significant vulnerability, Directors called for the development of contingency plans in case of spillovers from the international financial crisis on Macedonia's financial sector. They looked forward to the prompt passage of new legislation strengthening the central bank's power in dealing with troubled banks and enhancing its independence.

Directors welcomed the government's efforts to improve the business climate, attract foreign direct investment, and stimulate employment. They considered it essential to reinvigorate privatization plans, address the budgetary and trade deficit problems caused by artificially low electricity prices, and strengthen the social safety net to protect the poorest consumers. Directors also encouraged continued fiscal reforms aimed at improving public expenditure management and strengthening tax administration.

Public Information Notices (PINs) form part of the IMF's efforts to promote transparency of the IMF's views and analysis of economic developments and policies. With the consent of the country (or countries) concerned, PINs are issued after Executive Board discussions of Article IV consultations with member countries, of its surveillance of developments at the regional level, of post-program monitoring, and of ex post assessments of member countries with longer-term program engagements. PINs are also issued after Executive Board discussions of general policy matters, unless otherwise decided by the Executive Board in a particular case. 
FYR Macedonia: Selected Economic Indicators, 2004-08

\begin{tabular}{|c|c|c|c|c|c|}
\hline & 2004 & 2005 & 2006 & 2007 & $\begin{array}{l}2008 \\
\text { Proj. }\end{array}$ \\
\hline & \multicolumn{5}{|c|}{ (Percent change) } \\
\hline \multicolumn{6}{|l|}{ Real economy } \\
\hline Real GDP & 4.1 & 4.1 & 4.0 & 5.0 & 5.5 \\
\hline \multicolumn{6}{|l|}{ Consumer prices } \\
\hline Period average & -0.4 & 0.5 & 3.2 & 2.3 & 8.5 \\
\hline End of period & -2.1 & 1.6 & 3.0 & 6.7 & 5.5 \\
\hline Real wages, period average & 4.4 & 2.0 & 4.1 & 5.6 & $\ldots$ \\
\hline \multirow[t]{2}{*}{ Unemployment rate (average) } & 37.2 & 37.3 & 36.0 & 34.9 & 34.8 \\
\hline & \multicolumn{5}{|c|}{ (In percent of GDP, unless otherwise indicated) } \\
\hline \multicolumn{6}{|l|}{ Government finances } \\
\hline Central government balance & 0.7 & 0.3 & -0.5 & 0.6 & -1.5 \\
\hline Revenues (including grants) & 36.5 & 35.6 & 32.9 & 34.3 & 36.8 \\
\hline Expenditures & 35.8 & 35.3 & 33.4 & 33.7 & 38.2 \\
\hline \multicolumn{6}{|l|}{ Central Government debt 1/ } \\
\hline Gross & 36.6 & 39.5 & 31.5 & 24.2 & 21.7 \\
\hline Net & 32.5 & 31.9 & 22.5 & 25.6 & 17.8 \\
\hline \multicolumn{6}{|l|}{ Money and credit } \\
\hline Broad money (M3, percent change) & 16.1 & 14.9 & 24.5 & 29.4 & 13.0 \\
\hline Private sector credit growth (percent change) & 25.0 & 20.5 & 30.5 & 39.1 & 35.1 \\
\hline Short-term lending rate (percent) $2 /$ & 11.8 & 10.8 & 9.5 & 8.6 & 8.7 \\
\hline \multirow[t]{2}{*}{ NBRM short-term rate (28-day bill, end-period) $3 /$} & 10.0 & 8.5 & 5.8 & 4.8 & 7.0 \\
\hline & \multicolumn{5}{|c|}{ (In millions of euros, unless otherwise indicated) } \\
\hline \multicolumn{6}{|l|}{ Balance of payments } \\
\hline Exports & 1,345 & 1,643 & 1,903 & 2,441 & 2,949 \\
\hline Imports & 2,259 & 2,501 & 2,923 & 3,614 & 4,694 \\
\hline Trade balance & -914 & -858 & $-1,020$ & $-1,173$ & $-1,745$ \\
\hline In percent of GDP & -21.1 & -18.4 & -20.1 & -20.9 & -27.6 \\
\hline Current account balance & -363 & -121 & -45 & -171 & -881 \\
\hline In percent of GDP & -8.4 & -2.6 & -0.9 & -3.0 & -14.0 \\
\hline Overall balance & -23 & 345 & 305 & 65 & -65 \\
\hline Official gross reserves & 717 & 1,123 & 1,417 & 1,524 & 1,507 \\
\hline In months of imports & 2.9 & 4.0 & 4.1 & 3.4 & 3.2 \\
\hline External debt service ratio $4 /$ & 20.7 & 18.4 & 22.6 & 30.7 & 27.5 \\
\hline External debt to GDP ratio (percent) 5/ & 47.9 & 53.9 & 49.1 & 48.4 & 54.2 \\
\hline \multicolumn{6}{|l|}{ Exchange rate } \\
\hline Denars/Dollar (average) 6/ & 48.6 & 49.3 & 48.8 & 44.7 & 40.3 \\
\hline Denars/Euro (average) 6/ & 61.3 & 61.3 & 61.2 & 61.2 & 61.2 \\
\hline Real effective exchange rate (CPI-based, percent change) $7 /$ & -2.3 & -3.4 & -1.6 & -2.0 & 4.3 \\
\hline
\end{tabular}

Sources: Data provided by the authorities; and IMF staff projections.

1/ Movements in 2005 and 2006 reflect the issuance of a Euro 150 million Eurobond and repayment of the London club debt. Net debt is defined as gross debt minus NBRM deposits of the central government.

$2 /$ Weighted averages for December of each year. For 2008, the data is for September.

$3 /$ For 2008, the data is as of October.

4/ Debt service due including IMF as percent of exports of goods and services. Excludes rollover of trade credits.

5/ Total external debt, including trade credit. Revised methodology applied to data beginning in 2004.

6/ Data for 2008 is through end-September.

7/ Data for 2008 is through end-June. 


\section{Statement by Age Bakker, Executive Director for Former Yugoslav Republic of Macedonia and Mihai Tanasescu, Advisor to the Executive Director December 1, 2008}

On behalf of the authorities we thank staff for their report, analysis and recommendations. They appreciate the Fund's advice and the presentation of the topics covered in the Selected Issues report. In general, the authorities considered the staff appraisal helpful and the consultations with the Fund productive. Some nuances in views remain, especially related to the fiscal stance, but the authorities consider that the consultations again provided a good opportunity to focus on the economic aspects aimed at strengthening macroeconomic stability and intensifying structural reforms.

In 2008, the reelected government took office for a new four-year term that is expected to see Macedonia becoming a full member of NATO, and starting EU negotiations. The ongoing discussion with the EU act as an important anchor for macroeconomic stability. In such environment, the key objective of the authorities is to speed up progress in structural reforms, supporting key growth sectors of the economy and restructuring lagging ones.

\section{Economic performance and outlook}

Macedonia's economic performance remains strong. The country experienced more than five years of uninterrupted real output growth. Growth increased to 5.9 percent in 2007 and is expected to reach 6 percent in 2008, with industrial production growing at double digits. In 2007, improved terms of trade and increased remittances boosted incomes and domestic demand. However, the current account deficit widened to 14 percent of GDP this year, and the trade deficit is projected to rise from 21 percent of GDP in 2007 to 28 percent of GDP in 2008. Foreign direct investment rose 40 percent (y-o-y) in August, and now covers 74 percent of the current account gap, as compared to 68 percent before. Inflation has risen in the third quarter to 8.4 percent (y-o-y), but decelerated in October 2008 to 7.1 percent (y-o-y), with core inflation low at 2.3 percent in October 2008.

The recent international financial turmoil, and a shift to a more expansionary fiscal policy increased external vulnerabilities, and posed a more serious concern, both in terms of keeping sufficient international reserves under the fixed exchange rate, and of maintaining external debt sustainability. The authorities recognize the potential risks associated with Macedonia's external imbalances, especially in light of the dimming global growth outlook and persistent strains in commodity and financial markets. At the same time, the authorities are looking to implement some fiscal stimulus in 2009 and to move ahead with improving the infrastructure and to create a positive impact on the output of the private sector in the long run. 


\section{Fiscal policy}

The authorities have successfully pursued fiscal consolidation over the past several years. In 2007 , the general budget ran a small surplus of about 0.6 percent of GDP, well above the 1 percent deficit target. In the first three quarters of 2008, the central government ran a surplus of almost 3 percent of GDP. The fiscal consolidation was due to a strong revenue over performance and expenditures savings. The fiscal consolidation was possible because the main elements in the authorities' economic reform agenda are simplifying the tax system, improving its efficiency and reducing the tax burden. However, recently the government approved a budget rectification and raised the central government deficit for 2008 to 1.5 percent of GDP.

The government pledged to increase spending on public wages, pensions, agriculture and education and, with regard to the security reform, to cut social security contributions from 32 percent to 22 percent over three years. In these circumstances, the government intends to increase the deficit to 2.8 percent in 2009 and 3 percent in 2011. A deficit of this magnitude does not alter Macedonia's sound fundamentals, including the low level of public debt. Moreover, the security reform also includes introduction of the gross wage concept, integral collection of contributions by the Public Revenue Office, and broadening the tax base, which will strengthen the fiscal consolidation at longer term. At the same time, the authorities have taken measures to control the budgetary expenditures, both at the central and local levels.

Against this background, the authorities are fully committed to improve the fiscal stance if macroeconomic indicators will deteriorate in accordance with the recent financial turmoil, and ensure that fiscal expansion will not exacerbate Macedonia's medium-term external vulnerabilities. They agreed with staff's recommendations in adjusting the fiscal policy, if needed.

Consistent with their commitment to fiscal discipline, the tax administration reform has intensified arrears collection and improved tax collection from both large and small taxpayers. At the same time, the customs administration reform and the implementation of the fiscal decentralization will strengthen the fiscal stance and will increase budget revenues.

\section{Monetary policy and financial sector}

The National Bank of the Republic of Macedonia (NBRM) continues to support the economic program by maintaining a de facto pegged exchange rate regime backed by an adequate level of international reserves. However, the deceleration of world growth and severe deterioration in the terms of trade related to the turmoil in international financial markets negatively affected the current account and portfolio investments, thus limiting the increase in international reserves. However, it is expected that the reserve coverage at the end of the year will remain around 3 months of import, as in 2009 import demand might be lower than expected. The inflation rate started to accelerate as of August 2007 and reached 8.4 percent in the third quarter of 2008. The largest part was explained by supply side factors such as a pick-up in food and energy prices. As commodity prices started to decrease, the 
inflation rate in October 2008 decelerated to 7.1 percent, with core inflation remaining low at 2.3 percent $(\mathrm{y}-\mathrm{o}-\mathrm{y})$. Inflation expectations are currently stable, but the risks from wage increases are present and stress the need for strong vigilance from the NBRM. During 2008, the NBRM gradually raised its interest rate to 7 percent, as well as its capital adequacy requirements for overdraft and credit card loans, introduced measures aimed at discouraging the excessive credit growth of households, and broadened the base for reserve requirement, while still committing to further increasing interest rates, if needed. With increasing external vulnerabilities, the NBRM is committed to take further measures to slow credit growth and to continue to bring down the inflation rate.

The banking system remains healthy, and the recent international financial turmoil did not affect the banks directly. Its indirect impact, on the other hand, could lower economic growth and worsen the trade deficit or weaken remittances. Given the importance of financial sector stability, the authorities will work on strengthening the central bank's role in the legal and regulatory framework, and will continue to improve supervision on the non-bank financial sector.

\section{Structural reforms}

Macedonia has made significant progress on the structural reform side, attracting greenfield foreign direct investment, privatizing and restructuring the railway system, liberalizing the telecommunications, and improving the business climate by establishing the "one-stop-shop" and reducing the time required to register a business.

The recent measures approved by the government to reduce minimum social contributions, together with lower taxes on labor will stimulate employment and will encourage lower paid workers to enter the formal economy. The authorities will continue to improve public expenditures management, to help raise public investment to new EU member state levels, spending public funds more efficiently by integrating them into the annual budget process. Strengthening the tax administration allowed the government to improve tax collection and make more information available to taxpayers. Furthermore, the authorities will continue to harmonize the basis for social security contributions with the personal income tax, which will ease the computation burden and simplify the tax administration, and has the potential to raise additional revenues.

The authorities are committed to accelerate the electricity sector reform, by gradually eliminating the existing distortions by improving the companies' capacity to cover their costs. In this respect, the authorities will respect the independence of the energy regulatory commission in setting prices. At the same time, after ending electricity subsidies for large-users, the authorities are committed to continue to gradually increase the electricity prices for the domestic retail sector, and to take supplementary measures to protect the poorest electricity consumers.

Finally, we would like to express the authorities' commitment to continue to work with the international financial institutions in pursuing reforms that will help attract foreign direct investment. 